\title{
Spatial and temporal changes in the diet composition of the Eurasian eagle- owl (Bubo bubo) in Slovakia comparing three historical periods
}

\author{
Priestorové a časové rozdiely v zložení potravy výra skalného (Bubo bubo) na Slovensku \\ porovnaním troch historických periód
}

\section{Ján OBUCH}

\begin{abstract}
The author evaluates his own data on the food of the Eurasian eagle-owl (Bubo bubo) in Slovakia using material he collected between 1975 and 2020. A total of 105,543 food items were identified in 254 samples taken at 136 localities. Mammals had the highest representation (Mammalia, 65 species, 58.4\%), and the species composition of birds was diverse (Aves, minimally 140 species, $8.5 \%$ ), but the common frog (Rana temporaria, $32.0 \%$ ), from the lower vertebrates, is represented more abundantly. Invertebrates (Evertebrata, $0.1 \%$ ) occurred in food residues only occasionally. The bulk of the samples were collected from eagle-owl nests. The samples were divided into three time periods $(\mathrm{A}-\mathrm{C})$, which differ in the manner of human land-use management: A up to the 1950s, with a smaller area of field plots and more extensive grazing in the uplands; B from the 1950s to the 1980s, during the Socialist period, with the concentration of agricultural production in large units; C the last 30 years, 1990 to 2020, with the gradual break-up of collective land management. The first period (A) is characterised by a strong dominance of frogs, particularly the European brown frog $R$. temporaria (44.6\%), and a large share of small mammal species of the family Muridae (genera Apodemus and Mus). During the time of Socialism (B), eagle-owls adapted to hunting larger species of mammals and birds, and the share of frogs in their food fell by half (R. temporaria, 23.3\%). With the decline in livestock production after 1990 (period C), the species diversity of birds increased: aquatic species and raptors in particular are on the rise. Successive overgrowth of pastures in the submontane zone is reducing the hunting territories of eagle-owls. The dominance of the common vole (Microtus arvalis) in their diet has gradually increased from period A (26.8\%) to period C (37.3\%). Data from eleven areas around Slovakia are evaluated separately for the three time periods. In period A, the highest proportion of frogs was in the Liptov region ( $R$. temporaria, 68.2\%), when eagle-owls nested deeper in the mountains. The proportion of frogs decreased towards lower areas, and in the Ponitrie (Nitra river basin) it was only 10.8\%. At the same time, the share of M. arvalis and larger prey increased. A similar trend of increasing shares of larger prey towards lower locations also applied during the Socialist period (B). In the last 30 years (C), frogs in the higher river basins have given way to European water voles Arvicola amphibius and M. arvalis. In association with the progressive overgrowth of pastures, forest species such as the yellow-necked mouse (Apodemus flavicollis) and bank vole (Myodes glareolus) are increasingly prevalent, as are the white-breasted hedgehog (Erinaceus roumanicus) and various thrushes (Turdus sp.).
\end{abstract}

Abstrakt: Autor vyhodnocuje vlastné údaje o potrave výra skalného (Bubo bubo) z územia Slovenska z materiálu, ktorý zbieral v rokoch 1975 až 2020. Spolu z 254 vzoriek na 136 lokalitách bol determinovaný materál zo 105543 kusov potravy. Dominantné zastúpenie majú cicavce (Mammalia, 65 druhov, 58,4 \%). Pestré je druhové zloženie vtákov (Aves, minimálne 140 druhov, 8,5 $\%$ ), ale početnejšie je zastúpený z nižších stavovcov skokan hnedý (Rana temporaria, 32,0 \%). Len príležitostne sa vo zvyškoch potravy vyskytujú bezstavovce (Evertebrata, $0,1 \%$ ). Prevažná čast' vzoriek bola zbieraná na hniezdach výrov. Vzorky boli rozdelené do troch časových období (A - C), ktoré sa líšia spôsobom hospodárskeho využívania krajiny človekom: A do 50 rokov 20. storočia s menšou výmerou pol’ných parciel a s rozšírenejšou pastvou v pohoriach; B v 50. až 80. rokoch 20. storočia v období socializmu s koncentráciou pol’nohospodárskej výroby vo vel'kých celkoch; C posledných 30 rokov 1990 až 2020 s postupným rozkladom kolektívneho vlastníctva pôdy. Prvé obdobie (A) sa vyznačuje silnou dominanciou žiab, najmä druhu Rana temporaria (44,6 \%) a vel'kým podielom malých druhov cicavcov z čel'ade Muridae (rody Apodemus a Mus). V období socializmu (B) sa výry preorientovali na lov väčších druhov cicavcov a vtákov a podiel žiab klesol na polovicu (R. temporaria, 23,3 \%). Útlmom živočíšnej výroby po roku 1990 (obdobie C) sa zvyšuje druhová diverzita vtákov: pribúdajú najmä vodné druhy a dravce. Sukcesné zarastanie pasienkov v submontánnom pásme zmenšuje lovné teritóriá výrov. Dominancia hraboša pol’ného (Microtus arvalis) sa postupne zvyšuje od obdobia A $(26,8 \%)$ po obdobie C (37,3\%). Údaje z 11 oblastí Slovenska sa vyhodnocujú osobitne pre uvedené 3 časové obdobia. V období A bolo najvyššie zastúpenie žiab na Liptove (R. temporaria, 68,2 \%), ked' výry hniezdili hlbšie v pohoriach. Pomerné zastúpenie žiab sa znižovalo smerom do nižších polôh a na Ponitrí tvorilo len 10,8 \%. Zároveň sa zvyšoval podiel M. arvalis a väššej koristi. Podobný trend zvyšovania podielu väčšej koristi smerom do nižších polôh platil aj v období socializmu (B). V posledných 30 rokoch (C) sú vo vyššie položených kotlinách žaby nahrad- 
Obuch J: Spatial and temporal changes in the diet composition of the Eurasian eagle-owl (Bubo bubo) in Slovakia comparing three historical periods

zované hrabošovitými hlodavcami Arvicola amphibius a M. arvalis. V súvislosti so sukcesným zarastaním pasienkov sa zvyšuje podiel lesných druhov Apodemus flavicollis a Myodes glareolus, ale tiež ježa Erinaceus roumanicus a drozdov (Turdus sp.)

Key words: Eurasian eagle-owl, diet, Slovakia, spatial and temporal changes.

Ján Obuch, Comenius University, Faculty of Natural Science, Detached Unit, SK-038 15 Blatnica, Slovakia. E-mail: jan.obuch@uniba.sk.

Acknowledgements: I am grateful to several ornithologists for their help in acquiring material from the pellets of Eurasian eagleowls in Slovakia. Thanks also go to F. Tulis for drawing the researched localities on the map. I especially wish to thank Prof. Jozef Sládek from the Technical University in Zvolen, who directed me 50 years ago towards research on the feeding habits of owls. The ability to search for eagle-owls' nests on crags was enabled by training in rock-climbing, which I started with Ján Hazucha.

\section{Introduction}

The Eurasian eagle-owl (Bubo bubo) is an apex predator which in central European conditions responds to the presence of available prey depending on human land management in the agricultural steppe. This activity in Slovakia has changed significantly over the last 100 years, with the gradual collectivisation of agricultural production during the 40 years of Socialism (1950 to 1989). In 1955, 39\% of agricultural land was under common ownership; in 1961 this was up to $89 \%$ of the land (Tibenský 1978), and the last private lands in mountain areas were merged in the 1970s. The pasturage which prevailed in mountain areas (Häufler 1955) gradually disappeared, and pastures were converted into woodland as part of the delimitation designed to create a forest land fund. Pasturage was also gradually moved from mountain locations to foothill areas as a result of the establishing of national parks and protected landscape areas (Piscová et al. 2018). Since 1990 however, there has been a gradual dissolution of agricultural cooperatives and mainly a decline in animal production. The consequence is the successive overgrowth of former meadows and pastures in foothill areas with bushes and subsequently by forest stands, which has reduced the overall hunting area for Eurasian eagle-owls. In 1950 , woodland covered $36.2 \%$ of the area of Slovakia; in 1990 this was $40.3 \%$ and in $201941.3 \%$. The current annual increase is $10 \mathrm{~km}^{2}$ of forest area (Moravčík 2020).

The first data on the food of the Eurasian eagle-owl are from the interwar period and the 1960s, from the foothills of the Tatra Mts (Schaefer 1967, 1972). In their collected work on the diet of the eagle-owl from the entire Palearctic, Jánossy \& Schmidt (1970) present, in addition to Schaefer's interwar results, only the material of approximately 100 food items from the Slovenský kras Mts (Rožňava) and the Malá Fatra Mts (Terchová). Štollmann collected the pellets and Schmidt determined their content. I began my own systematic research in the mid-1970s. In addition to the areas that I processed, there are more comprehensive results from the Malé Karpaty Mts (Darolová 1990). My first studies of the eagle-owl diet were carried out in the Pohronie (Hron river basin, Obuch 1979), the Ponitrie (Nitra river basin, Obuch 1980a), the Turiec (Turiec Basin, Obuch \& Darola 1980, Obuch 1982), the Žilinská kotlina Basin (Obuch 1980b), the Liptov Basin (Vondráček \& Obuch 1980, Obuch 1981), the Muránská planina Plateau (Obuch 1985a, 2002a) and the Považie (Middle Váh river basin, Obuch 1985b). After 1990, the areas of the Slovenský kras Mts (Obuch 1992, 1998), the Rimavská kotlina Basin (Obuch 1995a, 2000), the Slovenský raj National Park (Obuch 1995b) and the Orava region (Obuch 1995c, Obuch \& Karaska 2010) were also examined. We pointed out the breeding of the Eurasian eagle-owls in the valleys of the Nizké Tatry Mts before their afforestation in connection with botanical (Kučera et al. 2009) and speleological research (Kudla et al. 2019). More recently, I have presented summary results from research on the eagle-owl diet in Slovakia (Obuch 2018a) and outlined changes over time in the composition of its diet in some regions of this country (Obuch 2017, 2018b).

In the past, the Eurasian eagle-owl was persecuted by hunters, especially in countries with a tradition of breeding small feathered and furry game (Andreska \& Andreska 2020). The first efforts to protect the Eurasian eagle-owl in the interwar period in Germany were linked with more comprehensive study of its diet (Uttendörfer 1939, 1952). At that time R. März devoted the most time to studying the food of the Eurasian eagleowl. His data from the Českolipsko region in the 
northern Czech Republic (März 1940) were followed up some 40 years later by Vondráček \& Honců (1978) and then after another 40 years by Andreska et al. (2021). A comparison of shorter time periods in the Nízky Jeseník Hills informed the work on the Eurasian eagle-owl diet by O. Suchý (Suchý 1980, 1990), which was followed by Havelková (2007). Following on from Schaefer's research in the 1930s and 1960s, I compared changes in the diet of the eagle-owl in 30-year periods in the Belianske Tatry Mts (Obuch 2002b).

In the work presented here, my own results are assessed after supplementation of data from 11 regions of Slovakia and their classification into three time segments. To make it possible to build on the current results in the future, I present in the appendices a complete list of identified species in the diet of Eurasian eagleowls in the individual studied areas.

\section{Material and methods}

The characteristics of the areas and a list of the Eurasian eagle-owl food samples used for individual time periods are provided in the appendices (Appendix 1). When characterising the areas, the climate is described according to Konček (1980). The locations of the studied areas and sites are drawn on the map of Slovakia (Fig. 1). Most of the osteological material comes from the nests of eagle-owls located on rock shelves and in shallow cavities. In Slovakia, Eurasian eagle-owls also nest on ledges below deeper cliff overhangs and in caves with clay bottoms close to the rock walls (Obuch 1994). In suitable locations, they use the same site, or multiple sites in the same rock massif, for several years. Each year they dig a nesting hole, mixing older and younger layers of bone as they do so. In the first collections in the 1970s and 1980s, I distinguished nests that were still being used at that time (period B, 40,833 prey items) from long-abandoned nests with bones in the deeper layers of the soil (period A, 50,795 pieces). Items gathered from nests used since 1990 were included in period $\mathrm{C}(13,915$ pieces). In some cases, a mixture of older bones were found in the eagle-owl nests which could not be separated due to the mixing. In such cases, the whole collection was assigned to the more recent period. This did not significantly affect the overall res-

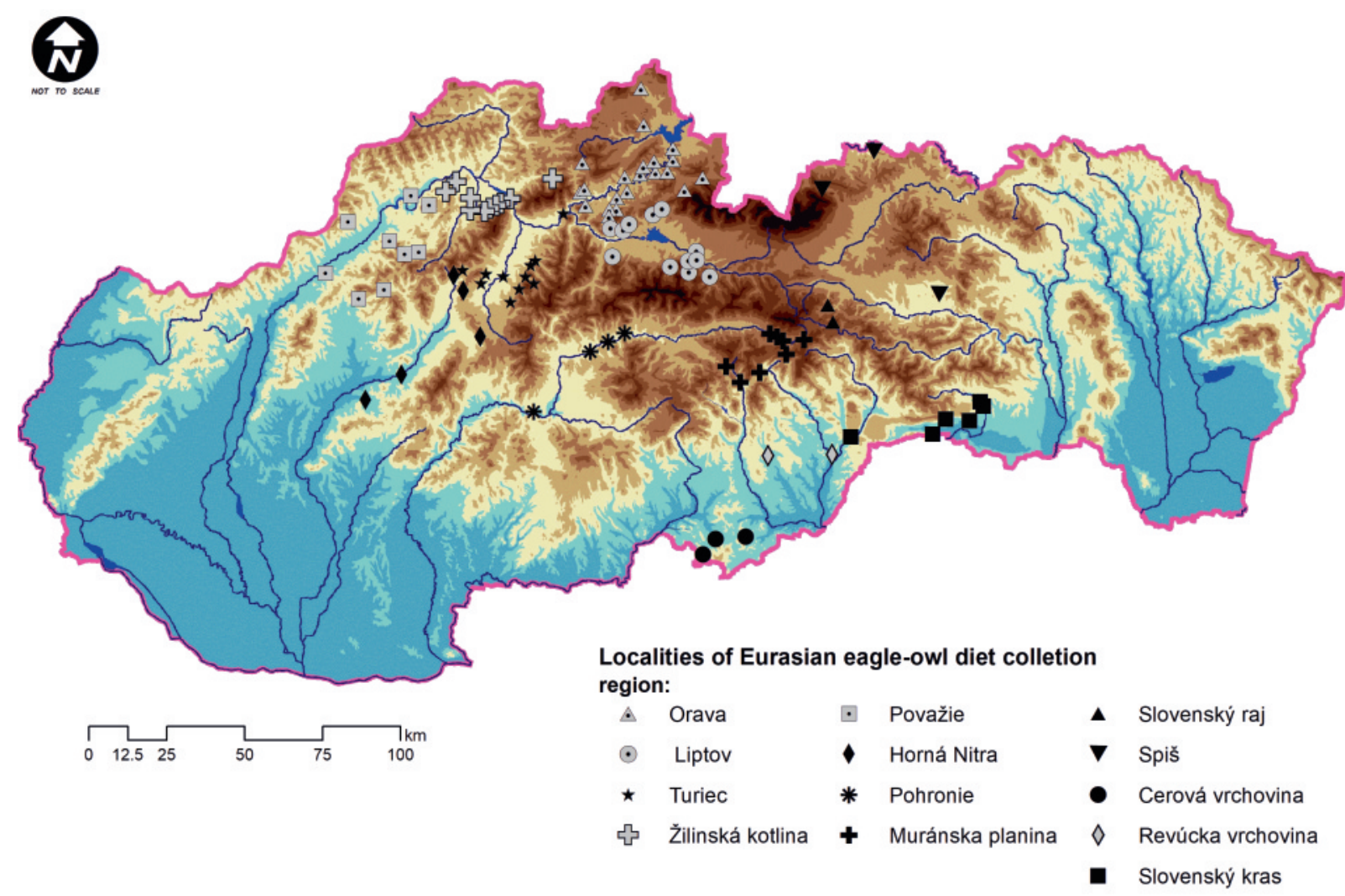

Fig. 1. Localities of Eurasian eagle-owl food sampling according to research area.

Obr. 1. Lokality zberov potravy výra skalného podl'a skúmaných oblastí. 
ult, because changes in the composition of fauna due to developments in land management occurred gradually over a period of one to two decades. Eagle-owls abandoned one of the nests in Komornícká dolina Valley after the death of one of the partners. Its skeleton, which was found near the nest, was dated by means of the radiocarbon method $(\mathrm{C} 14)$ with $68 \%$ probability to the period of $1860 \pm 30$ years. Similarly, the bones from extinct eagle-owl nests at the Sokol locality were dated using the radiocarbon method (C14) to period A (1890 \pm 50 years). On the basis of such dating, I assume that the vast majority of period A material is not older than 200 years (Kaizer et al. 2018). Most of the identified material came from the time of feeding the young in the spring. I removed food residues from nests by flooding the mixture of soil and passing it through a thick sieve in standing water. I soaked the fur from pellets and the organic impurities which floated to the surface of the water, together with the bones, in a hot solution of $5 \%$ $\mathrm{NaOH}$. The heavy bones sank to the bottom of the sieve and the impurities washed out of it. The heavier fraction of rock fragments was separated from the lighter bones at the bottom of the sieve by using circular movements. After drying, the jawbones of mammals (maxilla and mandible, or some teeth) were sorted from the bones for species identification. With hares the heelbones (calcaneus) were also sorted, and the forelegs (humerus) from moles. From birds I identified four types of bones: beaks, feet, shoulder of the wing and lower leg bones (rostrum, tarsometatarsus, humerus and metatarsus). I determined the species of frogs based on the pelvic bone (os ilium), carp-type fish based on the pharyngeal teeth (os pharyngeum inferior), other fish and reptiles based on the jawbones, and invertebrates based on the heads (caput). The author's comparative collections were used in the identification process. The number of each species in the sample was calculated as the minimum possible (MNI) based on the most numerous of the identified body parts. The species name Apodemus microps was used in this study for the central European population of Ural field mice (A. uralensis) and the subgenus name Terricola within the genus Microtus (for the pine vole species Terricola subterraneus and T. tatric$u s)$. Due to the unclear differentiation of bone fragments between hooded crows Corvus cornix and rooks C. frugilegus, we use the common name C. cornix + frugilegus. Because a different methodology for processing collections and their identification was used by other authors, in this work I evaluate only my own results. The disadvantage of using older works is the inaccuracy in the determination of some taxa of mammals and birds. Moreover, in my work up to the 1980 s, I identified Apodemus mice only to the genus level (Apodemus $\mathrm{sp}$.) and only later specified them at the species level (Obuch 2004).

I used the marked differences from the mean (MDFM) method (Obuch 2001). Data are presented in modified tables, in which the order of species is arranged such that they create blocks with positive MDFM values $(+1,+2)$ in the columns. The more numerous species without significant differences are listed below the dashed line, arranged according to decreasing total abundance. The bottom rows of the tables consist of the values of the diversity index H', calculated according to Shannon \& Weaver 1949. Other less numerous species are listed beneath Table 1 and below the results from the areas presented in the appendices. The Collection database program (Šipöcz 2004) was used when summarising the results from individual samples and constructing the modified tables.

\section{Results}

S u m m a r c o mparison of the food of the Eurasian e a gleow 1 from three periods in $\mathrm{S} 1 \mathrm{o} \mathrm{v}$ a k i a

Mammals predominate in the material comprising 105,543 items of Eurasian eagle-owl prey in 254 samples from 11 areas of Slovakia (Mammalia, 58.4\%, 45 species) (Table 1). Birds (Aves, 8.5\%, minimum 140 species) have a lower proportion, but with high species diversity. In contrast, in the lower vertebrates (Amphibia, Reptilia, Pisces, 33.0\%) one species of amphibian dominates: the common frog (Rana temporaria, 32.0\%). The common vole (Microtus arvalis, 31.2\%) has a similar prevalence among mammals, and among other mammals the European water vole Arvicola amphibius (7.2\%), wood mouse Apodemus sylvaticus (4.6\%) and brown rat Rattus norvegicus $(3.0 \%)$ are more numerous. The incidence of any individual bird species is less than $1 \%$.

The oldest period A is characterised by the small size of Eurasian eagle-owl prey, with high prevalence of $R$. temporaria (44.6\%), lower representation of $M$. arvalis $(26.8 \%)$, but a higher proportion of smaller mouse rodents (Muridae), especially Apodemus and Mus cf. musculus. The garden dormouse Eliomys quercinus was a relatively frequent species in all the compared areas of Slovakia. In the Socialist period B (30 to 70 years ago), the share of frogs in the Eurasian eagle-owl diet de- 
Tab. 1. Summary of comparisons of Eurasian eagle-owl diet compositions in Slovakia over three historical periods.

Tab. 1. Sumárne porovnanie zloženia potravy výra skalného na Slovensku z troch období.

\begin{tabular}{|c|c|c|c|c|c|c|c|c|}
\hline $\begin{array}{l}\text { period (years ago) / obdobie (roky pred) } \\
\text { period No. / obdobie č. } \\
\text { taxa / taxón }\end{array}$ & $\begin{array}{l}\text { A: } \\
1\end{array}$ & & $\begin{array}{l}\text { B: } \\
2\end{array}$ & & $\begin{array}{l}\text { C: } \\
3\end{array}$ & & $\Sigma$ & $\%$ \\
\hline Rana temporaria $(\mathrm{n} / \mathrm{ks})$ & $1+$ & 22,657 & $1-$ & 9523 & $2-$ & 1567 & 33,747 & 31.97 \\
\hline$\%$ & & 44.6 & & 23.32 & & 11.26 & & \\
\hline Pelophylax cf. esculentus & $1+$ & 197 & $1-$ & 45 & 2- & 7 & 249 & 0.24 \\
\hline Apodemus sylvaticus & $1+$ & 3123 & $1-$ & 1465 & $1-$ & 300 & 4888 & 4.63 \\
\hline Apodemus microps & $1+$ & 1227 & 2- & 177 & 2- & 42 & 1446 & 1.37 \\
\hline Apodemus agrarius & $1+$ & 293 & $1-$ & 102 & & 72 & 467 & 0.44 \\
\hline Mus cf. musculus & $1+$ & 617 & $1-$ & 270 & 1- & 69 & 956 & 0.91 \\
\hline Terricola subterraneus & $1+$ & 182 & & 116 & $2-$ & 8 & 306 & 0.29 \\
\hline Eliomys quercinus & $1+$ & 82 & $1-$ & 38 & $1-$ & 10 & 130 & 0.12 \\
\hline Gallus gallus dom. & $1+$ & 20 & $1-$ & 4 & & & 24 & 0.02 \\
\hline Galerida cristata & $1+$ & 29 & $1-$ & 8 & & 3 & 40 & 0.04 \\
\hline Lanius minor & $1+$ & 12 & & 1 & & & 13 & 0.01 \\
\hline Corvus cornix + frugilegus & $1-$ & 344 & $1+$ & 573 & & 149 & 1066 & 1.01 \\
\hline Perdix perdix & 2- & 188 & $1+$ & 655 & & 145 & 988 & 0.94 \\
\hline Phasianus colchicus & 2- & 14 & $1+$ & 80 & & 18 & 112 & 0.11 \\
\hline Columba palumbus & $1-$ & 34 & $1+$ & 70 & $1-$ & 7 & 111 & 0.11 \\
\hline Streptopelia turtur & $1-$ & 18 & $1+$ & 36 & & 8 & 62 & 0.06 \\
\hline Strix aluco & & 118 & $1+$ & 153 & $1-$ & 28 & 299 & 0.28 \\
\hline Turdus viscivorus & $1-$ & 27 & $1+$ & 41 & & 10 & 78 & 0.07 \\
\hline Nucifraga caryocatactes & $1-$ & 3 & $1+$ & 13 & & 3 & 19 & 0.02 \\
\hline Sciurus vulgaris & $1-$ & 95 & $1+$ & 154 & & 51 & 300 & 0.28 \\
\hline Mustela nivalis & $1-$ & 155 & $1+$ & 234 & & 58 & 447 & 0.42 \\
\hline Sorex araneus & $1-$ & 25 & $1+$ & 40 & & 9 & 74 & 0.07 \\
\hline Cypriniformes sp. & $2-$ & 25 & $1+$ & 119 & & 27 & 171 & 0.16 \\
\hline Erinaceus roumanicus & $1-$ & 177 & $1+$ & 614 & $1+$ & 301 & 1092 & 1.03 \\
\hline Lepus europaeus & $1-$ & 269 & $1+$ & 469 & $1+$ & 174 & 912 & 0.86 \\
\hline Arvicola amphibius & $1-$ & 1816 & $1+$ & 4337 & $1+$ & 1428 & 7581 & 7.18 \\
\hline Rattus norvegicus & $2-$ & 449 & $1+$ & 1561 & $2+$ & 1194 & 3204 & 3.04 \\
\hline Columba livia dom. & 3- & 47 & $1+$ & 287 & $2+$ & 242 & 576 & 0.55 \\
\hline Streptopelia decaocto & 3- & 1 & $1+$ & 35 & $1+$ & 25 & 61 & 0.06 \\
\hline Spermophilus citellus & $2-$ & 14 & $1+$ & 52 & $1+$ & 28 & 94 & 0.09 \\
\hline Asio otus & $2-$ & 98 & $1+$ & 309 & $1+$ & 172 & 579 & 0.55 \\
\hline Turdus merula & $2-$ & 36 & $1+$ & 128 & $2+$ & 100 & 264 & 0.25 \\
\hline Anas platyrhynchos & 2- & 20 & & 58 & $2+$ & 53 & 131 & 0.12 \\
\hline Gallinula chloropus & $2-$ & 10 & & 27 & $2+$ & 45 & 82 & 0.08 \\
\hline Tachybaptus ruficollis & $2-$ & 2 & & 9 & $2+$ & 27 & 38 & 0.04 \\
\hline Cricetus cricetus & & 179 & & 166 & $1+$ & 80 & 425 & 0.40 \\
\hline Apodemus flavicollis & & 1532 & & 1424 & $1+$ & 667 & 3623 & 3.43 \\
\hline Myodes glareolus & & 326 & & 349 & $1+$ & 138 & 813 & 0.77 \\
\hline Glis glis & $1-$ & 49 & & 76 & $1+$ & 39 & 164 & 0.16 \\
\hline Micromys minutus & & 29 & $1-$ & 11 & $2+$ & 38 & 78 & 0.07 \\
\hline Ondatra zibethicus & $2-$ & 0 & & 14 & $1+$ & 9 & 23 & 0.02 \\
\hline Anas crecca & $1-$ & 10 & & 11 & $1+$ & 17 & 38 & 0.04 \\
\hline Fulica atra & $2-$ & 2 & & 10 & $1+$ & 15 & 27 & 0.03 \\
\hline Rallus aquaticus & & 10 & & 7 & $1+$ & 8 & 25 & 0.02 \\
\hline Vanellus vanellus & $1-$ & 27 & & 70 & $1+$ & 46 & 143 & 0.14 \\
\hline Columba oenas & $1-$ & 40 & & 47 & $1+$ & 24 & 111 & 0.11 \\
\hline Buteo buteo & $1-$ & 20 & & 35 & $2+$ & 40 & 95 & 0.09 \\
\hline Falco tinnunculus & $1-$ & 56 & & 93 & $1+$ & 76 & 225 & 0.21 \\
\hline Accipiter gentilis & & 14 & & 13 & $1+$ & 12 & 39 & 0.04 \\
\hline Bubo bubo & $1-$ & 9 & & 21 & $1+$ & 12 & 42 & 0.04 \\
\hline Garrulus glandarius & $1-$ & 45 & & 79 & $2+$ & 83 & 207 & 0.20 \\
\hline Pica pica & $1-$ & 69 & & 79 & $1+$ & 57 & 205 & 0.19 \\
\hline Corvus corax & & 4 & & 4 & $1+$ & 8 & 16 & 0.02 \\
\hline
\end{tabular}


Obuch J: Spatial and temporal changes in the diet composition of the Eurasian eagle-owl (Bubo bubo) in Slovakia comparing three historical periods

Tab. 1. Continuation.

Tab. 1. Pokračovanie.

\begin{tabular}{|c|c|c|c|c|c|c|c|c|}
\hline $\begin{array}{l}\text { period (years ago) / obdobie (roky pred) } \\
\text { period No. / obdobie č. } \\
\text { taxa / taxón }\end{array}$ & \multicolumn{2}{|c|}{$\begin{array}{l}A:>70 \\
1\end{array}$} & \multicolumn{2}{|c|}{$\begin{array}{l}\text { B: } 30-70 \\
2\end{array}$} & \multicolumn{2}{|c|}{$\begin{array}{l}\mathrm{C}:<30 \\
3\end{array}$} & $\Sigma$ & $\%$ \\
\hline Turdus pilaris & $2-$ & 32 & & 79 & $2+$ & 71 & 182 & 0.17 \\
\hline Turdus philomelos & $1-$ & 99 & & 186 & $1+$ & 126 & 411 & 0.39 \\
\hline Sturnus vulgaris & $1-$ & 14 & & 42 & $1+$ & 27 & 83 & 0.08 \\
\hline Erithacus rubecula & $1-$ & 7 & & 12 & $1+$ & 11 & 30 & 0.03 \\
\hline Coccothraustes coccothr. & & 14 & & 10 & $1+$ & 14 & 38 & 0.04 \\
\hline Pelobates fuscus & & 85 & 2- & 25 & $2+$ & 87 & 197 & 0.19 \\
\hline Lucanus cervus & 2- & 1 & $2-$ & 1 & $2+$ & 34 & 36 & 0.03 \\
\hline Vulpes vulpes & $1-$ & 34 & & 51 & $1+$ & 23 & 108 & 0.1 \\
\hline Sorex minutus & $1-$ & 2 & & 9 & & 3 & 14 & 0.01 \\
\hline Cuculus canorus & $1-$ & 8 & & 22 & & 9 & 39 & 0.04 \\
\hline Anas querquedula & $1-$ & 6 & & 17 & & 7 & 30 & 0.03 \\
\hline Lacerta agilis & $1-$ & 16 & & 27 & & 12 & 55 & 0.05 \\
\hline Athene noctua & & 25 & $1-$ & 9 & & 8 & 42 & 0.04 \\
\hline Salmo trutta & & 119 & & 86 & $1-$ & 18 & 223 & 0.21 \\
\hline Nyctalus noctula & & 26 & & 16 & $1-$ & 1 & 43 & 0.04 \\
\hline Microtus arvalis (n/ks) & & $\overline{1}, \overline{6} \overline{0} \overline{4}$ & & $1 \overline{4}, \overline{177}$ & & $\overline{5} \overline{18} \overline{9}$ & $32, \overline{9} 70^{-}$ & 31.24 \\
\hline$\%$ & & 26.78 & & 34.75 & & 37.29 & & \\
\hline Talpa europaea & & 221 & & 189 & & 50 & 460 & 0.44 \\
\hline Coturnix coturnix & & 235 & & 141 & & 47 & 423 & 0.40 \\
\hline Alauda arvensis & & 157 & & 140 & & 51 & 348 & 0.33 \\
\hline Scolopax rusticola & & 117 & & 111 & & 28 & 256 & 0.24 \\
\hline Coloeus monedula & & 114 & & 100 & & 29 & 243 & 0.23 \\
\hline Microtus agrestis & & 78 & & 85 & & 19 & 182 & 0.17 \\
\hline Muscardinus avellanarius & & 68 & & 66 & & 14 & 148 & 0.14 \\
\hline Mustela erminea & & 53 & & 66 & & 19 & 138 & 0.13 \\
\hline Crex crex & & 39 & & 45 & & 16 & 100 & 0.09 \\
\hline Mammalia, 65 species / druhov & & 25,008 & & 26,565 & $1+$ & 10,083 & 61,656 & 58.42 \\
\hline Aves, min. 140 species / druhov & 1- & 2588 & $1+$ & 4338 & $1+$ & 2047 & 8973 & 8.50 \\
\hline Amphibia, Reptilia, Pisces & $1+$ & 23,176 & 1- & 9910 & 2- & 1739 & 34,825 & 33.00 \\
\hline Evertebrata & 1- & 23 & 1- & 20 & $2+$ & 46 & 89 & 0.08 \\
\hline$\Sigma$ & & 50,795 & & 40,833 & & 13,915 & 105,543 & 100.00 \\
\hline Diversity index H' & & 2.01 & & 2.45 & & 2.67 & 2.35 & \\
\hline
\end{tabular}

Others prey species (Period no.-no. of items) / Ostatné druhy (Obdobie č. - počet):

Neomys anomalus (1-14; 2-7; 3-2), Neomys fodiens (1-38; 2-25; 3-6), Crocidura leucodon (1-17; 2-9), Crocidura suaveolens (1$17 ; 2-18 ; 3-6)$, Rhinolophus ferrumequinum (2-1), Rhinolophus hipposideros (1-2; 2-1), Myotis mystacinus (1-4; 2-6), Myotis brandtii (1-1; 2-1), Myotis emarginatus (3-1), Myotis nattereri (1-1; 2-1), Myotis bechsteinii (1-5; 2-4), Myotis myotis (1-23; 2-30; 37), Myotis blythii (1-2; 2-1), Vespertilio murinus (1-15; 2-10; 3-2), Eptesicus serotinus (1-32; 2-28; 3-4), Eptesicus nilssonii (3-1), Pipistrellus pipistrellus (1-10; 2-9; 3-1), Barbastella barbastellus (1-13; 2-10), Plecotus auritus (1-3; 2-6), Plecotus austriacus (21), Dryomys nitedula (1-37; 2-29; 3-5), Sicista betulina $(1-17 ; 2-13 ; 3-5)$, Rattus rattus (1-3), Terricola tatricus (1-5; 2-4; 3-1), Alexandromys oeconomus (1-1; 3-1), Chionomys nivalis (1-6; 2-5), Canis familiaris $(1-1 ; 3-1)$, Martes foina (1-1; 2-1), Martes sp. $(1-1 ; 2-3)$, Mustela putorius (1-4; 2-7), Mustela eversmanii $(1-1 ; 2-2)$, Mustela vison (3-1), Felis catus dom. (1-3; 2-4; 3-4), Sus scrofa (1-3), Cervus elaphus (2-1; 3-1), Capreolus capreolus (1-1), Capra ibex hircus (1-1), Ovis ammon aries (1-1; 3-1), Podiceps cristatus (2-1), Podiceps grisegena (2-1), Podiceps nigricollis (2-1; 3-3), Ixobrychus minutus (2-1; 3-1), Nycticorax nycticorax (2-1), Anser anser dom. (1-1), Anser fabalis (1-1), Mareca penelope (1-1), Anas acuta (2-1; 3-2), Aythya fuligula (2-1; 33), Bucephala clangula (2-1), Anatidae sp. (1-12; 2-18; 3-2), Accipiter nisus (1-13; 2-8; 3-8), Pernis apivorus (2-2), Aquila pomarina (3-1), Aquila sp. (3-1), Circus aeruginosus (3-2), Circus sp. (1-1; 2-2), Accipitridae sp. (1-1; 2-2; 3-1), Falco peregrinus $(1-4 ; 2-4 ; 3-1)$, Falco subbuteo (3-2), Falco sp. (1-3; 2-3), Tetrastes bonasia (1-18; 2-15; 3-5), Lyrurus tetrix (1-4; 2-8), Tetrao urogallus (1-2; 2-4), Meleagris gallopavo dom. (3-1), Galliformes sp. (1-2; 3-1), Porzana porzana (1-10; 2-13; 3-7), Zapornia parva $(1-1 ; 2-1 ; 3-2)$, Porzana sp. (1-1), Rallidae sp. (1-1; 2-3), Charadrius dubius (1-2; 2-10; 3-1), Pluvialis apricaria (2-1; 3-1), Tringa glareola (1-1; 2-3), Tringa ochropus (2-1), Tringa sp. (1-4; 2-2), Actitis hypoleucos (1-20; 2-12; 3-5), Philomachus pugnax (1-5; 2-2), Limosa limosa (1-1), Gallinago gallinago (1-5; 2-6; 3-6), Gallinago sp. (2-4), Lymnocryptes minimus (3-1), Limicolae sp. (2-4), Chroicocephalus ridibundus (2-2; 3-4), Sterna hirundo (1-1; 2-2; 3-1), Chlidonias niger (1-2; 2-2), Columba sp. (1-6), Tyto alba (1-3; 2-4; 3-2), Asio flammeus (1-2; 2-3; 3-2), Otus scops (1-2), Aegolius funereus (1-17; 2-13; 3-3), Strix uralensis (11; 2-3; 3-3), Caprimulgus europaeus (1-8; 2-12; 3-4), Apus apus (1-2; 2-1; 3-1), Coracias garrulus (2-3), Upupa epops (2-1), 
Tab. 1. Continuation.

Tab. 1. Pokračovanie.

Dryocopus martius (1-1; 2-8; 3-1), Picus canus (1-2), Picus viridis (2-2; 3-2), Dendrocopos major (1-1; 2-3), Dendrocopos syriacus (1-1; 3-1), Dendrocopos medius (2-1), Dendrocopos leucotos (1-1), Jynx torquilla (1-1; 2-3; 3-1), Lullula arborea (1-18; 212; 3-2), Hirundo rustica (1-4; 2-2; 3-1), Delichon urbicum (1-11; 2-12; 3-4), Riparia riparia (2-2), Anthus trivialis (1-4; 2-7), Anthus pratensis (3-1), Anthus spinoletta (1-3), Motacilla alba (1-6; 2-8), Motacilla cinerea (2-2; 3-1), Bombycilla garrulus (2-1), Lanius excubitor (1-1; 2-2; 3-1), Lanius collurio (1-19; 2-17; 3-3), Acrocephalus palustris (2-1; 3-1), Hippolais icterina (1-2), Sylvia atricapilla (1-2; 2-3; 3-2), Sylvia sp. (1-1), Phylloscopus sibilatrix (1-2), Regulus sp. (2-1), Sylviidae sp. (1-6; 2-1), Muscicapa striata (1-1; 2-1), Saxicola rubetra (2-1), Oenanthe oenanthe (1-2; 2-1), Phoenicurus ochruros (2-2; 3-4), Turdus torquatus (1-13; 2-17; 3-7), Turdus iliacus (1-3; 2-3), Turdus sp. (2-2), Parus major (1-4; 2-3; 3-1), Periparus ater (3-1), Cyanistes caeruleus (2-2; 3-1), Lophophanes cristatus (3-2), Poecile palustris (1-2), Parus sp. (2-1), Sitta europaea (2-1; 3-1), Troglodytes troglodytes (1-1; 2-1), Cinclus cinclus (1-1; 2-1; 3-1), Emberiza citrinella (1-20; 2-22; 3-10), Emberiza calandra (1-4; 2-2), Emberiza schoeniclus (1$1 ; 2-2)$, Emberiza sp. (1-1), Fringilla coelebs $(1-17 ; 2-13 ; 3-10)$, Carduelis carduelis (1-4; 2-5; 3-4), Carduelis spinus (3-1), Carduelis cannabina (1-2; 2-2; 3-2), Carduelis chloris (1-2; 2-2; 3-3), Pyrrhula pyrrhula (1-1; 2-1), Serinus serinus (1-1; 2-1), Loxia curvirostra (1-2; 2-5), Fringillidae sp. (1-2), Passer domesticus (1-13; 2-14; 3-5), Passer montanus (1-1; 2-2; 3-3), Oriolus oriolus (1-1; 2-1), Passeriformes sp. (1-43; 2-61; 3-10), Passeriformes sp. juv. (1-1), Aves sp. (1-1; 2-21; 3-2), Aves sp. juv. (1-6; 28; 3-4), Bombina variegata (1-2), Bombina sp. (2-1), Bufo bufo (1-10; 2-14; 3-2), Bufotes viridis (1-3; 2-3; 3-1), Bufo sp. (1-2; 31), Hyla arborea (1-5), Rana dalmatina (1-1; 2-2), Rana arvalis (2-1), Pelophylax ridibundus (1-2; 2-3; 3-3), Anguis fragilis (1-1), Lacerta viridis $(1-9 ; 2-12 ; 3-3)$, Lacerta muralis $(1-1 ; 2-5 ; 3-2)$, Lacerta sp. (1-4; 2-3; 3-1), Zootoeca vivipara (1-1; 2-2; 3-3), Natrix natrix (1-4; 2-1), Colubridae sp. (1-1; 2-3; 3-2), Serpentes sp. (2-4), Pisces sp. (1-31; 2-31; 3-3), Hymenoptera sp. (1-1), Coleoptera sp. (1-14; 2-14; 3-11), Astacus sp. (1-1), Limacidae sp. (1-6; 2-5; 3-1).

Note: Numerical data in the table are given in absolute values, and positive and negative deviations (e.g $1+, 2+, 1$-, 2-) are marked deviations from the mean (MDFM, Obuch 2001 ) for the species in these samples (see Methods).

Poznámka: Číselné hodnoty v tabulke sú uvedené v absolútnych hodnotách, kladné a záporné odchýlky $(1+, 2+, 1$-, 2- a podobne) sú výrazné odchýlky od priemeru (MDFM, Obuch 2001 ) druhov vo vzorkách (pozri Metodiku).

creased by nearly half ( $R$. temporaria, $23.3 \%$ ), and the share of $M$. arvalis increased less significantly (34.8\%), ut the representation of larger prey from the classes of mammals increased significantly: northern whitebreasted hedgehog Erinaceus roumanicus, European hare Lepus europaeus, $R$. norvegicus and A. amphibius, as did the birds: Corvus cornix + frugilegus, grey partridge Perdix perdix, common pheasant Phasianus colchicus, domestic pigeon Columba livia domestica and long-eared owl Asio otus. Some of these species still form a large part of the diet of eagle-owls even in period C (the last 30 years). This period is characterised by a further decrease in the number of $R$. temporaria $(11.3 \%)$ and a slight increase in the share of $M$. arvalis (37.3\%), but the proportion of forest rodent species $A$. flavicollis and M. glareolus has also increased, as has the diversity of birds, particularly waterfowl species, owls, and thrushes (genus Turdus) in particular from the songbirds.

Comparison of Eurasian e a g l e-ow diet composition i n s e veral a rea $\mathrm{s}$ of $\mathrm{Slovakia}$ A - Period more than 70 years ago (Table 2): In the Liptov region we have finds of eagle-owls nests from this period in the Nízke Tatry Mts, which were deforested and grazed by sheep in the 16th-17th centuries: from Demänovská dolina Valley, Jánská dolina Valley, the valley below Malužina and from Komornícká dolina Valley. R. temporaria $(68.2 \%)$ had high predominance in these finds, but the following mountain rodent species also occurred: European snow vole (Chionomys nivalis), northern birch mouse (Sicista betulina), hazel dormouse (Muscardinus avellanarius) and forest dormouse (Dryomys nitedula). The Ural field mouse (A. microps) also penetrated deeper into the mountains, and the European hamster (Cricetus cricetus) occurred in the finds from the edge of the Liptovská kotlina Basin. In the Orava region, which has a mosaic of narrow fields, meadows and pastures with discontinuous wooded enclaves, the prevalence of $R$. temporaria $(42.4 \%)$ was lower, and $M$. arvalis had a higher proportion (29.0\%), as did $R$. norvegicus and $A$. amphibius among the larger prey. In the Turiec area, eagle-owls nested on the border of a more intensively-farmed basin, so there was a greater share of rodents $M$. arvalis (32.2\%), $R$. norvegicus and M. musculus, and the hamster species $C$. cricetus and common spadefoot toad (Pelobates fuscus) still occurred here. In the Žilinská kotlina Basin and the Rajecká kotlina Basin, the proportions of $R$. temporaria 


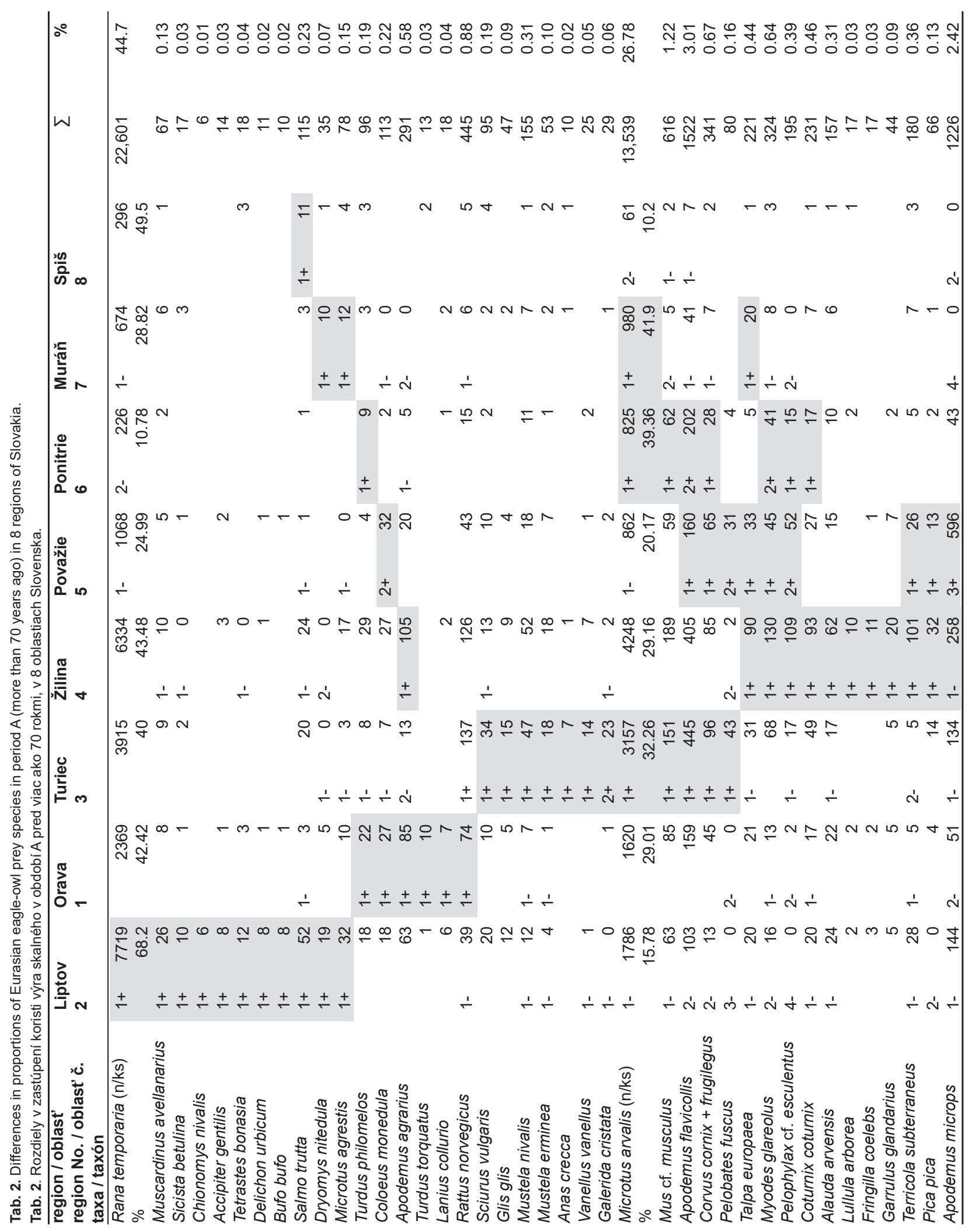




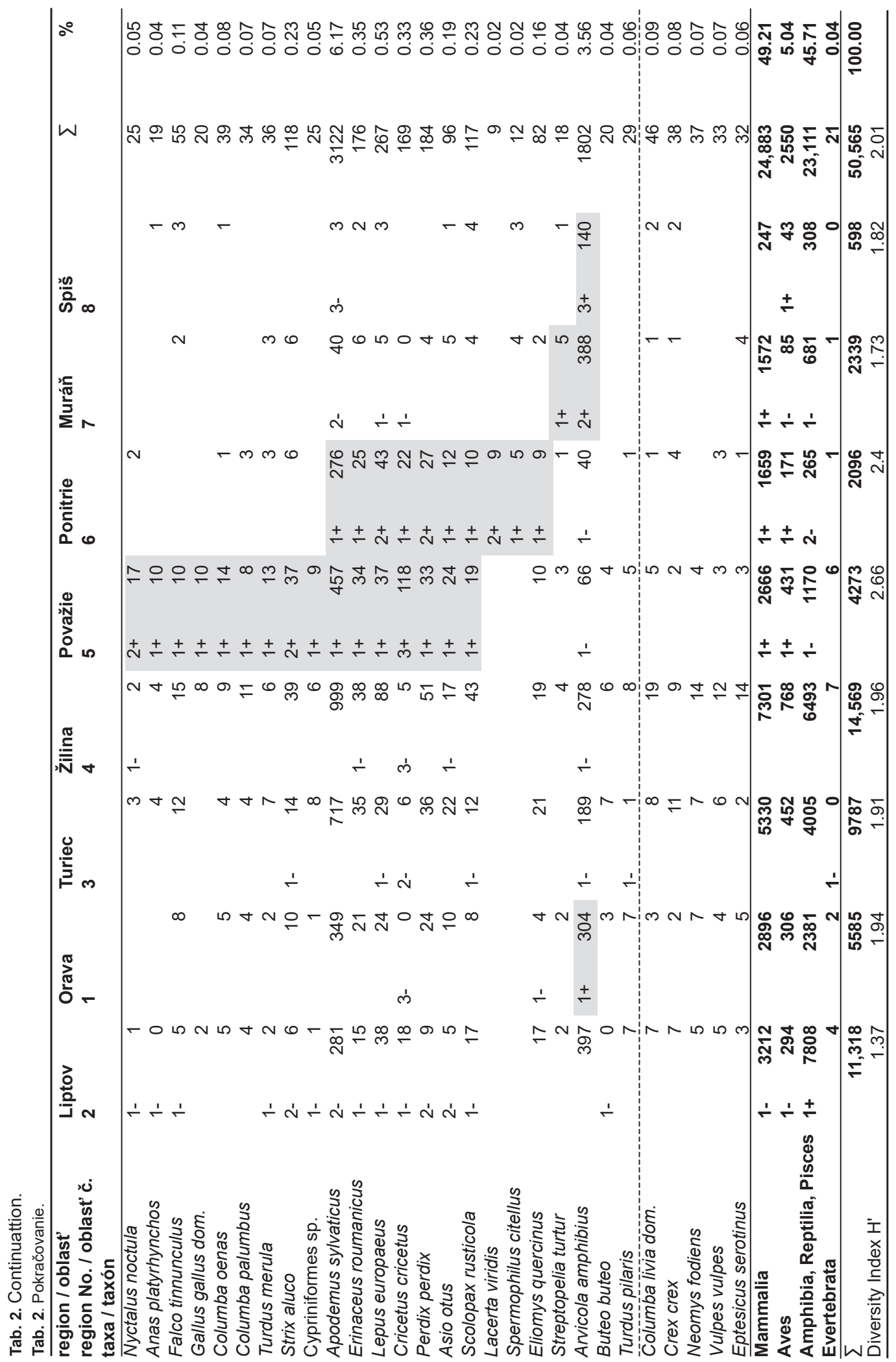


and $M$. arvalis were average, but the proportion of the edible frog (Pelophylax cf. esculentus) was higher, as was that of certain rodents: A. agrarius, $M$. glareolus and T. subterraneus and some birds: Eurasian skylark (Alauda arvensis), common quail (Coturnix coturnix), Eurasian jay (Garrulus glandarius) and common magpie (Pica pica). In the lower valley of the Považie region, along with $R$. temporaria (25.0\%), the toad species $P$. fuscus was also more numerous among the amphibians, in addition to the larger mammalian species E. roumanicus, $L$. europaeus and $C$. cricetus and the mouse species $A$. microps, as well as the larger bird species $P$. perdix, the pigeons Columba palumbus and $C$. oenas, and the owls A. otus and Strix aluco. In the warmer Ponitrie basin, the eagle-owl diet featured a low proportion of $R$. temporaria $(10.8 \%)$, as larger prey from the bird and mammal classes were available. In contrast, on the crags along the outer perimeter of the Muránská planina Plateau, where there is less arable land and more meadows and pastures, the voles $M$. arvalis $(41.9 \%)$ and $A$. amphibius dominated.

B - The period of Socialism, 30 to 70 years ago (Table 3): fter the regime change in 1948, gradual changes in land use followed due to the collectivisation of agriculture, afforestation of pastures on steeper slopes and more intensive breeding of small game. These changes were manifested in the food strategy of the Eurasian eagle-owls: they started leaving the mountain locations and hunting for more prey in the foothills. The Liptov and Turiec regions still had relatively high proportions of $R$. temporaria $(44.5 \%$ and $29.4 \%$ respectively), as did Orava with $M$. arvalis $(41.8 \%)$ and together with the Horehronie and Spiš regions also $A$. amphibius. The lower parts of Považie, Ponitrie and Pohronie basins had higher proportions of larger species of birds in the eagle-owl diet, in particular P. perdix, $P$. colchicus, C. livia domestica, A. otus and C. cornix + frugilegus, and among mammals mainly hedgehogs $E$. roumanicus and hares L. europaeus. In the Ponitrie basin, Spiš region and the Slovenský kras karst area there was higher representation of $R$. norvegicus and $C$. cricetus, and locally also of European ground squirrel (Spermophilis citellus). Among the dormice, the garden dormouse (Eliomys quercinus) was more frequently hunted in the Turiec area, and in the Slovenský kras area the dormice Glis glis and D. nitedula. Among the smaller species of mice, Mus musculus was more numerous in the Turiec area, A. sylvaticus and A. flavicollis in the Považie and Ponitrie basins, and previously more abundant occurrence of $A$. microps was narrowed to the territories of the Ponitrie basin, Spiš region and Slovenský kras area. In the latter area, the occurrence of $P$. fuscus was more frequent as well, although previously it was a more numerous amphibian also in the higherelevated basins.

C - Period of the last 30 years (Table 4): In the upper basins of the Orava, Liptov and Horehronie regions, arable land has been gradually transformed into grassy surfaces since the 1990s. The decline in frogs in the eagle-owl diet was compensated with a higher share of voles $M$. arvalis and A. amphibius. In the Žilinská kotlina and Turiec basins, the progressive overgrowth of grasslands by trees was manifested in increased representation of the forest species A. flavicollis and M. glareolus. The larger species E. roumanicus, L. europaeus, $R$. norvegicus and $C$. livia domestica were more abundantly hunted depending on local conditions in different parts of Slovakia. The occurrence of the species $A$. microps, C. cricetus and P. fuscus shifted to lower positions. During the Socialist period, the pheasant $P$. colchicus was also released into the wild in the Liptov and Turiec basins, where it was decimated under the pressure of predators and currently occurs only in the lower basins. Special conditions occur in the drier Spiš region, which lies in the rain shadow of the Tatra Mts; for this reason the steppe species $S$. citellus, C. cricetus and $A$. microps still occur here. In contrast, a peculiarity of the lower valley of the Turňa River in the Slovenský kras area are ponds and water meadows, meaning that aquatic bird species as well as the European water vole A. amphibius are more abundantly represented here.

Changes in the Eurasian e a g le-ow d i e t in individual a r e a s of S lova ki a

Orava (Appendix 2): Overall, the species M. arvalis $(37.5 \%), R$. temporaria $(28.8 \%)$ and A. amphibius $(11.6 \%)$ dominate in all three time periods. Birds have a share of $7.6 \%$. In the oldest period (A), the proportions of frogs ( $R$. temporaria, $42.4 \%$ ) and murine rodents $A$. sylvaticus, A. microps, A. agrarius and M. musculus were significantly higher. Among the birds, the representation of the western jackdaw (Coloeus monedula), at that time nesting in rocky massifs, was more numerous. During the Socialist period (B), the proportion of frogs was reduced by half ( $R$. temporaria, 22.5\%) and the proportion of vole-type rodents $M$. arvalis and $A$. amphibius increased. A further $50 \%$ decline in the incidence of frogs in the most recent period (C) was caused by the availability of larger prey from the mammalian 
classes: E. roumanicus, $R$. norvegicus, Sciuris vulgaris, Mustela nivalis and birds C. livia domestica, P. perdix, Buteo buteo, A. otus, G. glandarius and C. cornix.

Liptov (Appendix 3): In total, $R$. temporaria (58.1\%), M. arvalis $(19.0 \%)$ and A. amphibius $(6.3 \%)$ dominate in all periods. Birds have a $4.8 \%$ share. The proportion of frogs ( $R$. temporaria, 68.2\%) was extremely high in the oldest period (A), and this fell to $44.5 \%$ in the period of Socialism (B) and reaches only $4.0 \%$ in recently-sampled material $(\mathrm{C})$. In period $\mathrm{A}$, the Ural field mouse (A. microps) penetrated high into the mountains with pasturage. At the same time, the vole Chionomys nivalis descended to the valleys from alpine positions. In the Liptovská kotlina Basin, Eurasian eagle-owls hunted the hamster $C$. cricetus. In the period of Socialism (B), the mammals L. europaeus, Talpa europaea, A. flavicollis, M. glareolus and M. nivalis were more often hunted, and among the birds $P$. perdix, F. tinnunculus, C. livia domestica, Columba palumbus, Strix aluco, Turdus merula and Coturnix coturnix. In the present period (C) the proportion of mammals E. roumanicus, $R$. norvegicus, A. amphibius and M. arvalis, is increasing, and among the birds A. otus, Vanellus vanellus, Anas platyrhynchos, G. glandarius and Pica pica are now more prevalent.

Turiec (Appendix 4): The dominance of $M$. arvalis increased slightly from $32.3 \%$ in the oldest period (A) to $44.4 \%$ in the present (C). In contrast, the share of $R$. temporaria decreased from $40.0 \%$ in period A to $19.3 \%$ in period C. In the oldest period other species of frogs also appeared in the eagle-owl diet, but are currently absent: Pelophylax cf. esculentus and Pelobates fuscus. In period A, murine rodents A. sylvaticus, A. microps and M. musculus were more numerous, and currently the forest species A. flavicollis and M. glareolus are more abundant. At present, the proportion of birds (Aves) has increased, in particular thrushes (Turdus), crows and rooks (Corvidae), domestic pigeons (C. livia domest$i c a$ ), partridges ( $P$. perdix) and certain species of raptors and owls. During the Socialist period (B), the proportion of larger mammal species in the food of B. bubo increased: E. roumanicus, $R$. norvegicus and $A$. amphibius.

Žilinská kotlina Basin (Appendix 5): In total for all periods, the species $R$. temporaria (36.6\%) and $M$. arvalis $(30.4 \%)$ were predominantly represented in the eagle-owl diet, while birds (Aves) had 7.7\% representation. The decline in the dominance of $R$. temporaria from $43.5 \%$ in period $\mathrm{A}$ to $8.5 \%$ at present $(\mathrm{C})$ is significant. The proportion of small mice A. microps, $A$. sylvaticus and $M$. musculus also fell, while the proportion of A. flavicollis, A. agrarius and M. glareolus increased. From the Socialist period (B) up to the present (C), a higher representation of larger prey species has persisted: E. roumanicus, L. europaeus, $R$. norvegicus, A. amphibius, A. otus and C. livia domestica. Among the birds, the following species were more numerous in the period of Socialism (B): P. perdix, P. colchicus and $C$. cornix + frugilegus, while in the latest period (C) the share of the common kestrel $F$. tinnunculus and thrushes (genus Turdus) has increased.

Považie (Appendix 6): In the lower parts of the Váh Valley, I collected material from eagle-owl pellets only from older periods $\mathrm{A}$ and $\mathrm{B}$, and in the last 30 years I have not collected its food remnants in this area. The share of $R$. temporaria was lower $(25.0 \%)$ in the oldest period (A) than in the higher-located valleys, and in the period of Socialism it fell to $5.0 \%$. Among the frogs, the species $P$. cf. esculentus and P. fuscus were more abundantly represented in period $\mathrm{A}$, and mammalian species $A$. microps and $C$. cricetus were more prevalent then. In the period of Socialism (B), the share of M. arvalis in the Eurasian eagle-owl diet increased significantly from $20.2 \%$ to $35.6 \%$, and similarly as in the Žilinská kotlina Basin, the proportion of larger species of mammals and birds increased, except for A. amphibius. Carp-type fish (Cypriniformes) were hunted more frequently in localities near the Váh River.

Ponitrie (Appendix 7): Similarly as in the Považie area, the Ponitrie area has a warmer climate, but it is drier. For this reason, even in the oldest period, the proportion of $R$. temporaria was lower in the Eurasian eagle-owl diet, dropping from $10.8 \%$ in period $\mathrm{A}$ to $0.3 \%$ in period $\mathrm{C}$. The dominant species $M$. arvalis $(34.4 \%)$ showed a moderately declining trend (from $39.4 \%$ in period A to $27.5 \%$ in period C). The share of small murine rodents decreased significantly. In the period of Socialism (B) they were superseded by the larger rodent species $A$. amphibius and the birds $P$. perdix, P. colchicus, C. cornix + frugilegus and A. otus. In the latest period (C) mammals are more abundantly represented: E. roumanicus, $R$. norvegicus and $C$. cricetus, and among birds the domestic pigeon $C$. livia domestica and thrushes . The hare (L. europaeus, $2.5 \%$ ) is evenly represented in the compared periods.

Pohronie (Appendix 8): The Pohronie region has similar climatic conditions as the Považie and Ponitrie basins. The Hron Valley, however, is predominantly narrower with less arable land. I have smaller samples of eagle-owl food from this area, which, however, confirms 


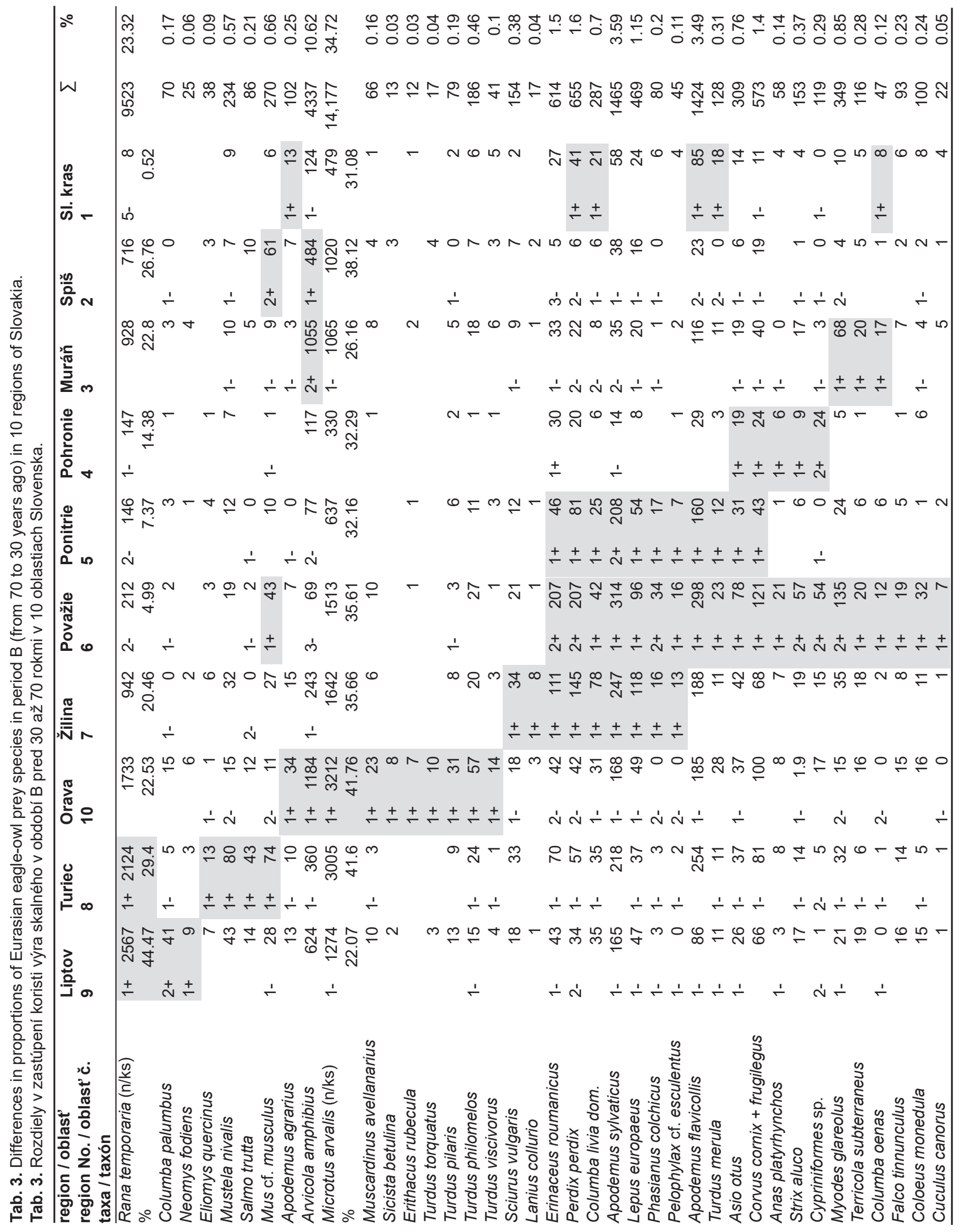




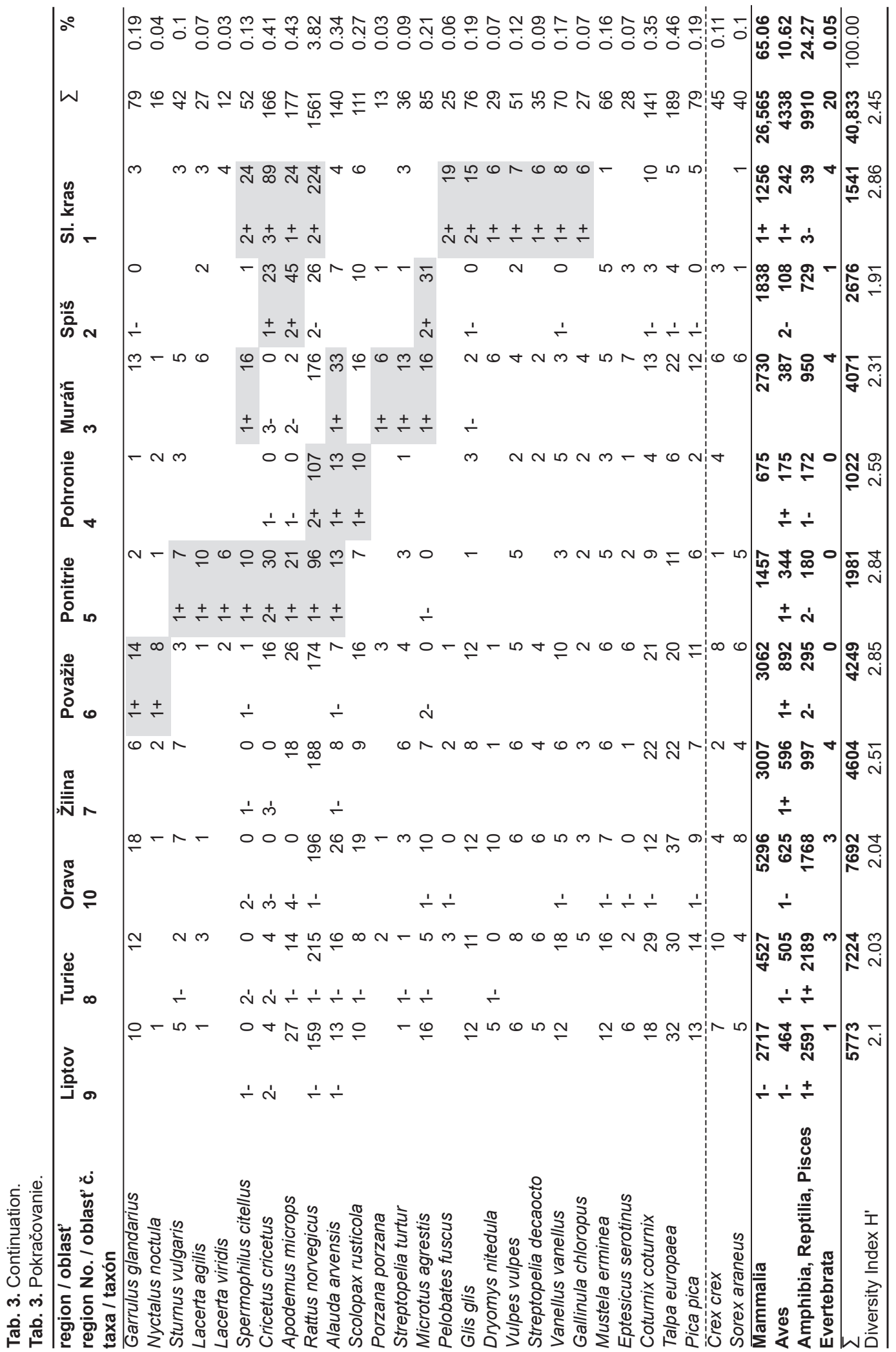




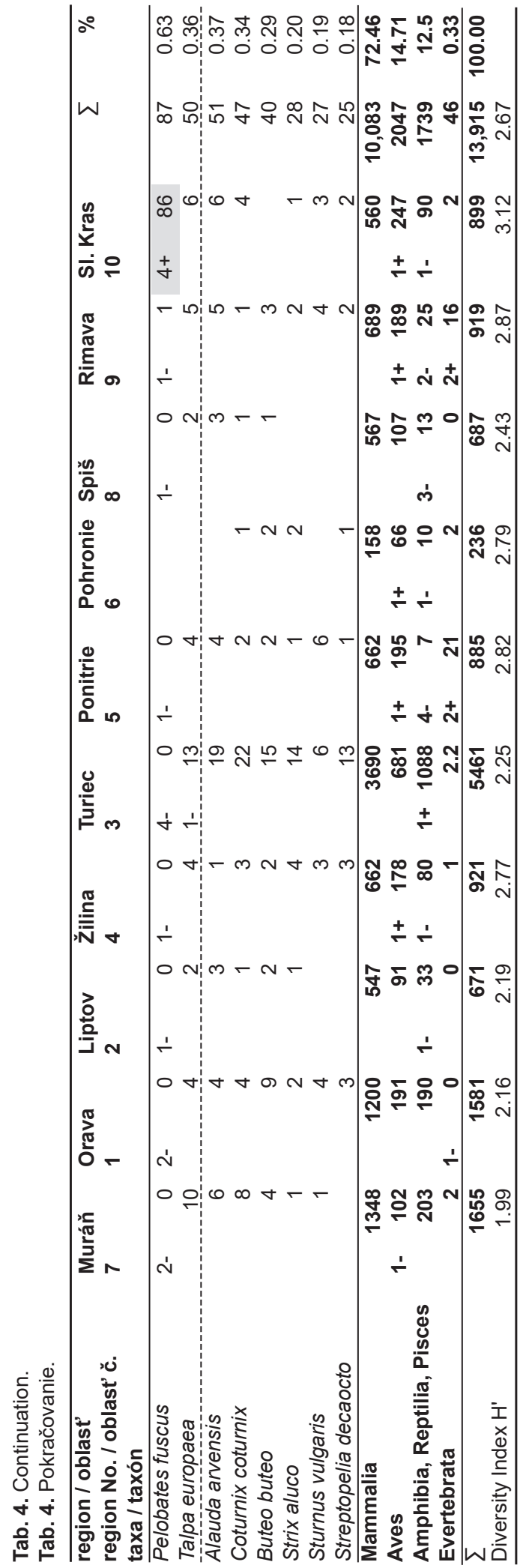

a higher proportion of $R$. temporaria in the oldest period (A) and the dominance of $M$. arvalis in the diet (29.2\%) and an increase in the proportion of larger prey in the most recent period (C), particularly the species $R$. norvegicus and $E$. roumanicus.

Muráňska planina Plateau (Appendix 9): Eurasian eagle-owls nested on the crags located around the perimeter of the plateau in its warmer southern part and in the colder part of the Horehronie basin. From the latest period (C) I have samples only from the Horehronie area. Only meadows and pastures feature here, and arable land is nearly absent. In the oldest period (A), smaller prey was represented mainly in the high proportion of $M$. arvalis $(41.9 \%), R$. temporaria $(28.8 \%)$ and A. sylvaticus. The decline in their representation during the Socialist period (B) was mainly offset by an increase in the proportion of $A$. amphibius and birds. The proportion of larger prey, mainly A. amphibi$u s$ and $R$. norvegicus, has further increased in the last 30 years (period C).

Spiš (Appendix 10): This extensive area from Slovenský raj National Park in the south to the Pieniny Mts in the north has a cold but drier climate due to the rain shadow of the Tatra Mts and the connection with the Galicia area in southern Poland. The oldest eagle-owl food samples (period A) come from the Slovenský raj National Park. In them there are high proportions of $R$. temporaria (49.5\%) and A. amphibius and a low representation of $M$. arvalis (10.2\%). Samples from the last 30 years $(C)$ are from the Dreveník Crags with a low proportion of $R$. temporaria $(0.15 \%)$ but a high share of $M$. arvalis (38.4\%). Among the larger mammalian species are $R$. norvegicus, $C$. cricetus, $S$. citellus, E. roumanicus and $L$. europaeus and among birds P. perdix, A. otus and the Corvidae.

Rimavská kotlina Basin (Appendix 11): Eurasian eagle-owls nest around the perimeter of the Rimavská kotlina Basin in the Cerová vrchovina and Revúcká vrchovina Uplands. I have food samples from this area only from the last 70 years (B and C), when the species $M$. arvalis $(25.3 \%)$ and $R$. norvegicus $(20.7 \%)$ dominated, the proportion of birds was higher (Aves, 22.0\%) and the frog $R$. temporaria lower (1.0\%). More significant differences between the periods occurred in the proportion of Apodemus mices: in the period of Socialism, the species A. flavicollis and A. sylvaticus were more numerous, and the proportion of $A$. agrarius is currently increasing.

Slovenský kras Karst (Appendix 12): Eurasian eagle-owls nest on crags around the perimeter of the 
karst plateaux bordering with an agricultural landscape and having a warm climate. In the valley of the Turña River there are larger ponds and water meadows. In the older eagle-owl food samples (period A) the representation of $M$. arvalis was higher (over $30 \%$ ); in period B also mice (genus Apodemus), rats ( $R$. norvegicus) and hamsters $(C$. cricetus). In the most recent period $(C)$ the share of $A$. amphibius has increased, among birds the species C. livia domestica, C. cornix + frugilegus and aquatic species, and among frogs the species $P$. fuscus. Larger species of mammals $E$. roumanicus, $L$. europaeus and $S$. citellus and birds $P$. perdix and $A$. otus are evenly represented in the eagle-owl diet in the compared three time periods.

\section{Discussion}

When determining the age of bones from food residues of Eurasian eagle-owls in their nests, a problem arises due to their mixing of the upper layer to a depth of 5-10 $\mathrm{cm}$ when digging the nesting hole. After a certain time, the deeper layer is no longer disturbed; it is harder, so it can be separated, collected independently and assigned to an older period. Below shallow overhangs, after filling the sediment to a certain height, the eagle-owls leave the nest and settle elsewhere in the same rock massif. For example, at Plešovice (near Blatnica in the Turiec basin) they successively used eight places for nesting, where more than 10,000 food items were accumulated over more than 200 years. Sometimes, however, alternating of several places occurred in the same time period. In Komornícka dolina Valley in the Liptov region, they used four locations for nesting and at an additional three sites there were bones from their pellets (Kudla et al. 2019). After afforestation of the surrounding pastures during the Socialist period, they flew lower down into the basin for food, but after the crags became shaded by forest growth, they left the area. In most other localities, there were fewer suitable nesting sites and the eagle-owls used only one or two locations for a long period. In the Turiec basin, the Sokol locality was the most suitable place for nesting, where bones from 3,556 prey items were accumulated. After the nest was crushed by a large boulder, the eagleowls left it and in the following years nested in less suitable habitats. In the Liptov and Turiec regions there were several suitable nesting habitats deeper in the mountains, which were abandoned after afforestation of the surrounding meadows and pastures caused the eagle-owls to move to less suitable places on the edge of the basins. There are fewer food remnants left by
Eurasian eagle-owls in these places, which indicates little successful nesting due to predation of young eagles by carnivores or birds of prey. In the Žilinská kotlina Basin, the majority of the nests used during the Socialist period (B) have since been abandoned, based on inspections made in the last ten years. However, monitoring by vocalising indicates the eagle-owls have not left these localities completely, but they are probably nesting in less suitable habitats (Kicko 2017). At present, it is difficult to find crags at the edge of the mountains which climbers do not frequent, hikers do not adapt as viewpoints, or the inhabitants of the surrounding villages do not use as a picnic places. Most of the Eurasian eagleowl food residues come from nests, and for the above reasons we obtained significantly less food samples from the latest period $(\mathrm{C})$ than from the previous two periods.

From period A, we made most finds of eagle-owl pellets in higher mountain locations, where there was a lack of larger prey and they were forced to use frogs to successfully rear their young. The advantage here was safe nesting sites. From period B, the nests were closer to intensively-farmed land with larger prey available, but with the risk of persecution by hunters due to the owls preying on small feathered and furry game, although by a decree from 1965 the Eurasian eagle-owl belonged among the protected animal species. In period $\mathrm{C}$, a decline in animal production occurred and thus a reduction in the food supply in abandoned farmyards and successive overgrowth of pastures in the foothills. The nesting of Eurasian eagle-owls in lowlands with an absence of crags, in abandoned buildings (Hrtan 2010), in the nests of raptors or in huts (Mihók \& Lipták 2010) is being increasingly observed. There is a strong population of eagle-owls at present in northern Germany, where there are no crags suitable for nesting at all (e.g. Lindner 2010). The Eurasian eagle-owls have nested in areas with the absence of crags in the past, as evidenced by their long-term monitoring in the Nízky Jeseník Hills in Moravia (Suchý 1980, 1990). I obtained a larger number of small samples from 14 less suitable habitats from period C in the Ponitrie area, where L. Šnírer devoted himself intensively to studying their nesting.

My material summarizing the diet of the Eurasian eagle-owl in the territory of Slovakia over the last 200 years is a testimony to changes in the composition of fauna, especially birds and mammals, depending on changes in the economic use of land by humans. The shift from higher elevated basins in the north of Slovakia to lower locations in southern areas due to success- 
ive overgrowth of meadows and pastures is most pronounced in the increasing incidence of small mammalian species $A$. microps and $C$. cricetus, and frogs of the species $P$. fuscus in the owls' diet. A marked decline in incidence of the garden dormouse (Eliomys quercinus) is evident over the whole territory. In contrast, the current state is in line with the abundance of $A$. amphibius and E. roumanicus at higher elevations, and birds now feature more often among the prey of eagleowls, for example, the domestic pigeon (C. livia domestica) and thrushes, but also various species of birds linked to the aquatic environment.

We processed similarly rich material from the recent and subrecent period in the area of central Norway (Obuch \& Bangjord 2016). Frogs ( $R$. temporaria, $36.7 \%$ ) also dominated in a nest found at Hommelvik from a period of 300 years ago. Large numbers of this species are still present, especially in localities along the sea coast (e.g. Ormhaugfjellet, $R$. temporaria, 50.7\%). This species was introduced on Frøya Island 30 years ago and has become an important part of the nutrition of juveniles, although larger prey is available there, particularly marine bird species. The significant decline in $R$. temporaria in the diet of eagle-owls in Slovakia may therefore be partly associated with the decrease in this species over the last 30 years, similarly as reported by Jeřábková \& Zavadil (2020) in the Czech Republic. At a site on Halmøya Island the oldest layer of bones in the nest of an Eurasian eagle-owl dates back to 2500 years ago, and the next layer is from the period when the island was inhabited by the Vikings in the Middle Ages. At present, the island is uninhabited and overgrown with bushes. Changes due to the human settlement of the island are reflected in the composition of the food of the Eurasian eagle-owl in this locality. In the original steppe areas, e.g. in southern Kyrgyzstan (Obuch \& Rybin 1993) or in Iran (Obuch 2014), the rich spectrum of prey of this apex predator indicates the spatial diffusion of native species of mammals depending on habitat conditions, although these too have been influenced by human activity down the millennia.

\section{References}

Andreska J \& Andreska D 2020: Changes in the Eurasian eagle-owl (Bubo bubo) population in Czechia and their association with legal protection. Raptor Journal 14: 29-44. DOI: 10.2478/srj-2020-0003.

Andreska J, Obuch J, Kurka P \& Honců M 2021: Potrava výra velkého (Bubo bubo) na Českolipsku ve třech periodách v období 1939-2018 [The food of the Eurasian eagle-owl (Bubo bubo) in the Česká Lípa region (Northern Bohemia, Czech Republic) in three periods between 1939-2018]. Sylvia 57: 3951. [In Czech with English abstract]

Darolová A 1990: Food composition in the Eagle owl (Bubo bubo Linneus, 1758) in Small Carpathians. Biológia 45: 831-840.

Havelková Š 2007: Potravní ekologie výra velkého (Bubo bubo) v Nízkém Jeseníku [Diet ecology of Eurasian eagle owl (Bubo bubo) in Nízký Jeseník Mts.]. Diplomová práce, Univerzita Palackého v Olomouci, Př́rodovědná fakulta, Katedra zoologie. [In Czech with English abstract]

Häufler V 1955: Horské oblasti v Československu a jejich využití [The mountain regions of Czechoslovakia and their economic utilization]. Nakladatelství ČSAV, Praha. [In Czech with Russian and English summaries].

Hrtan E 2010: The nesting of the Eurasian eagle owl (Bubo bubo) in man-made buildings. Slovak Raptor Journal 4: 103-104. DOI: 10.2478/v10262-0120051-1.

Jánossy D \& Schmidt E 1970: Die Nahrung des Uhus (Bubo bubo). Regionale und erdzeitliche Änderungen. Bonn. zool. Beitr. 21: 25-51.

Jeřábková L \& Zavadil V 2020: Atlas rozš́iření obojživelníků České republiky [Atlas of amphibian distribution in Czech Republic]. AOPK ČR, Praha. [ In Czech]

Kaizer J, Obuch J, Kontul' I, Šivo A, Richtáriková M, Čech P \& Povinec PP 2018: Methods of radiocarbon age determination in wine and bone samples using gas proportional counting technique. Radiocarbon 60: 1139-1149. DOI: 10.1017/RDC.2018.20.

Kicko J 2017: Hustota populácie výra skalného (Bubo bubo) vo vybranej časti okresu Žilina [Eagle owl (Bubo bubo) population density in a selected part of Žilina district], 42-46. In: Kalaš M \& Kicko J (eds), Výskum a ochrana Malej Fatry 2017. Fatranský spolok, Varín. [In Slovak with English abstract]

Konček M 1980: Klimatické oblasti [Climatic regions], 64. In: Mazúr E (ed), Atlas Slovenskej socialistickej republiky. Veda \& Slovenská kartografia, Bratislava. [In Slovak]

Kudla M, Holúbek P, Obuch J \& Litva J 2019: Základná speleologická a zoologická charakteristika jaskýn̆ v oblasti brál Mladucha v Komorníckej doline, Nízke Tatry [Basic geological, geomorphological 
and zoological characteristics of caves in the Mladucha Crags area of Komornícka dolina Valley, Low Tatra Mts.]. Slovenský kras 57: 177-196. [In Slovak with English abstract]

Kučera P, Bernátová D \& Obuch J 2009: Demänovská dolina bezbuková? [Is the Demänovská dolina Valley beechless?]. Naturea tutela 13 (1): 31-42. [In Slovak with English abstract]

Lindner M 2010: Uhubruten auf dem Ohlsdorfer Friedhof und weitere Uhubrutplätze in Hamburg und Helsinki. Eulen Rundblick 60: 88-90.

März R 1940: Querschnitt durch eine mehrjährige Nahrungskontrole einiger Uhupaare. Beitr. Fortpfl. Vögel 16: 1-27.

Mihók J \& Lipták J 2010: The Eurasian eagle-owl (Bubo bubo) nesting in a nest box on a very high voltage electricity pylon. Slovak Raptor Journal 4: 99-101. DOI: 10.2478/v10262-012-0049-8.

Moravč́k M 2020: Report on the Forest Sector of the Slovak Republic 2019. Green Report. Abridged Version. Ministry for Agriculture and Rural Development of the Slovak Republic, Bratislava.

Obuch J 1979: Náčrt potravnej ekológie výrov skalných (Bubo bubo), sídliacich v ŠPR Boky [Foraging ecology of the eagle owl (Bubo bubo) in the Boky Nature Reserve], 64-69. In: Sládek J (ed), 14. tábor ochrancov prírody. Prehl'ad odborných výsledkov. ÚV SZOPK, Prievidza. [In Slovak]

Obuch J 1980: Náčrt potravnej ekológie výra skalného (Bubo bubo) na Hornej Nitre [Foraging ecology of the eagle owl (Bubo bubo) in the Horná Nitra region], 99-103. In: Galvánek J \& Šimurková A (eds), 15. tábor ochrancov prírody. Prehl'ad odborných výsledkov. ÚV SZOPK, Prievidza. [In Slovak].

Obuch J 1980: Náčrt potravnej ekológie výra skalného. [Eine Skizze der Nahrungsökologie des Uhus (Bubo bubo L.) in den Brutplätzen im Kreis Žilina]. Vlastivedný zborník Považia 14: 245-265. [In Slovak with German and Russian summaries]

Obuch J 1981: Recentné osteologické nálezy z oblasti Choča [The recent osteological findings from Choč Mt. area]. Liptov 6: 257-270.

Obuch J 1982: Náčrt potravnej ekológie sov (Striges) v strednej časti Turca [Foraging ecology of owls (Striges) in the middle part of Turiec region]. Kmetianum 6: 81-107. [ In Slovak with summaries in Russian and German]

Obuch J 1985a: Osteologické nálezy z Muránskej planiny [Osteological finds from Muránska planina
Plateau]. Stredné Slovensko, Prírodné vedy 4: 160193. [In Slovak with summaries in Russian, German and English]

Obuch J 1985b: K potrave výra skalného (Bubo bubo) v okrese Považská Bystrica [On the diet of Eurasian eagle-owl (Bubo bubo) in Považská Bystrica district], 103-108. In: Galvánek J \& Gregor J (eds): XIX. tábor ochrancov prírody 1983, Prehl'ad odborných výsledkov. ÚV SZOPK \& OK ONV, Bratislava \& Považská Bystrica. [In Slovak]

Obuch J 1992: Potrava sov v okolí Moldavy nad Bodvou [Diet of owls in surroundings of Moldava nad Bodvou town], 190-197. In: Fulín M (ed), 15. Východoslovenský tábor ochrancov prírody, Prehl'ad odborných výsledkov, Moldava nad Bodvou. [In Slovak]

Obuch J 1994: Druhy osteologických nálezísk v krase [Types of osteological finds in a karst area]. Spravodaj SSS 2/1994: 19-24. [In Slovak].

Obuch J 1995a: Materiály k potrave sov v okolí Rimavskej Soboty [Data on owls' diet in the surroundings of the town Rimavská Sobota], 109113. In: Krištín A \& Gaálová K (eds), Rimava 1995, Odborné výsledky zoologických a mykologických výskumov, SAŽP \& ÚEL, Banská Bystrica \& Zvolen. [In Slovak with English summary]

Obuch J 1995b: Potrava niektorých vtáčích predátorov v Slovenskom raji [Diet of some bird predators in Slovenský raj National Park], 83-87. In: Odborný seminár k 30. výročiu ochrany prírody Slovenského raja, Čingov, 25.-26. 10. 1994, Ministerstvo životného prostredia SR \& Správa NP Slovenský raj, Bratislava \& Spišská Nová Ves. [In Slovak]

Obuch J 1995c: Potrava výra skalného (Bubo bubo) $\mathrm{v}$ údolí Oravy [The diet of the Eurasian eagle owl (Bubo bubo) in the Orava Valley], 79-82. In: Belanský P \& Removčíková O (eds), Rieka Orava a jej prírodné hodnoty, Zborník referátov zo seminára 23. 11. 1995, OÚŽP \& OV SZOPK, Dolný Kubín. [In Slovak]

Obuch J 2000: Potrava sov v Drienčanskom krase a v okolitých územiach [The diet of owls in the Drienčanský kras Karst and surrounding areas (central southern Slovakia)], 255-266. In: Kliment J (ed), Príroda Drienčanského krasu, ŠOP SR, Banská Bystrica. [In Slovak with English abstract]

Obuch J 2001: Using marked differences from the mean (MDFM) method for evaluation of contingency tables. Buteo 12: 37-46.

Obuch J 2002a: Podhorský typ potravy výra skalného 
(Bubo bubo) na Horehroní [Submontane type of Eurasian eagle owl diet (Bubo bubo) in the Horehronie region], 163-169. In: Uhrin M (ed), Výskum a ochrana prírody Muránskej planiny 3, Správa Národného parku Muránska planina, Revúca. [In Slovak with English abstract]

Obuch J 2002b: Potrava sov v oblasti Tatier: 65-ročná história výskumu [Diet of owls in the Tatra Mts. region: 65 years old history of research]. Oecologia Montana 11 (1-2): 77-81. [In Slovak with English abstract]

Obuch J 2004: Zastúpenie ryšaviek (rod Apodemus) $\mathrm{v}$ potrave sov (Strigiformes) na Slovensku [Representation of field mice (genus Apodemus) in the diet of owls (Strigiformes) in Slovakia], 67-80. In: Adamec M \& Urban P (eds), Výskum a ochrana cicavcov na Slovensku VI. Zborník referátov z konferencie (Zvolen 10.-11. 10. 2003). Štátna ochrana prírody SR, Centrum ochrany prírody a krajiny, Banská Bystrica. [In Slovak with English abstract]

Obuch J 2014: Spatial diversity in the diet of the Eurasian eagle owl Bubo bubo in Iran. Podoces 9: 721.

Obuch J 2017: Časové zmeny v potrave výra skalného (Bubo bubo) v Žilinskej kotline [Temporal changes in the diet of Eurasian eagle owl (Bubo bubo) in Žilinská kotlina Basin, NW Slovakia], 47-49. In: Kalaš M \& Kicko J (eds), Výskum a ochrana Malej Fatry. Zborník referátov z konferencie. Gbel'any, 5. 10. 2017. [In Slovak with English abstract]

Obuch J 2018a: Príklady časových zmien v pomernom zastúpení koristi u výra skalného (Bubo bubo) na Považí [Examples of temporal changes in relative abundance of prey of Eurasian eagle owl (Bubo bubo) in Považie region], 15. In: Kropil R \& Lešo P (eds), Aplikovaná ornitológia 2018 - Zborník abstraktov. Technická univerzita vo Zvolene, Zvolen. [In Slovak]

Obuch J 2018b: Potrava výra skalného (Bubo bubo) $\mathrm{v}$ niektorých regiónoch Slovenska [Diet of Eurasian eagle owl (Bubo bubo) in some Slovak regions], 80. In: Kubovčík V \& Stašilov $\mathrm{S}$ (eds), Zborník abstraktov z vedeckého kongresu „Zoológia 2018“, 22. - 24. 11. 2018. Technická univerzita vo Zvolene, Zvolen. [In Slovak]

Obuch J \& Bangjord G 2016: The Eurasian eagle-owl (Bubo bubo) diet in the Trondelag region (central Norway). Slovak Raptor Journal 10: 51-64. DOI: 10.1515/srj-2016-0005.
Obuch J \& Darola J 1980: Poznatky o zložení a vývoji teriofauny Gaderskej doliny na základe osteologických nálezov [Information on the composition and evolution of terriofauna in the Gader Valley based on osteological deposits]. Výskumné práce ochrany prírody 3C: 325-354. [In Slovak with Russian, German and English summaries]

Obuch J \& Karaska D 2010: The Eurasian eagle owl (Bubo bubo) diet in the Orava region (N Slovakia). Slovak Raptor Journal 4: 83-98. DOI: 10.2478/ v10262-012-0048-9.

Obuch J \& Rybin SN 1993: Food of the eagle owl (Bubo bubo zaissanensis Chachlov) in southern Kirghizia (Osh District). Folia Zoologica 42: 19-31.

Piscová V (ed) 2018: Využívanie vysokohorskej krajiny a jeho dôsledky na zmenu prostredia (na príklade Tatier a Nízkych Tatier) [Use of the alpine landscape and its impact on changes in the environment (case study of High and Low Tatra Mts)]. Veda, Bratislava. [In Slovak with English summary]

Schaefer H 1967: Gewöllstudien und andere Erinnerungen an die Hohe Tatra. Sborník prác o Tatranskom národnom parku 10: 313-318.

Schaefer H 1972: Neues von Uhu (Bubo bubo) in der Hohen Tatra. Ochrana fauny 6: 159-165.

Shannon CE \& Weaver W 1949: The mathematical theory of communication. University of Illinois Press, Urbana.

Suchý O 1980: K potravě výra velkého (Bubo bubo L.) v Jeseníkách [Zur Ernährung des Uhus (Bubu bubo L.) in Jeseníky]. Zprávy MOS 38: 85-97. [In Czech with German summary].

Suchý O 1990: Výr velký (Bubo bubo L.) v Jeseníkách po deseti letech [Der Uhu (Bubo bubo L.) in Jeseníky (Gesenke) nach zehn Jahren]. Zprávy MOS 48: 7-32. [In Czech with German summary]

Šipöcz T 2004: Zber. Databázový program. Verzia 3 [Collection. Database program. Version 3]. Botanical Garden. Commenius University in Bratislava, Blatnica.

Tibenský J 1978: Slovensko 1, Dejiny [Slovakia 1, History]. Obzor, Bratislava. [In Slovak]

Vondráček J \& Honců M 1978: Porovnání dvou analýz zbytků potravy výra velkého (Bubo bubo L.) z téže lokality v letech 1939 a 1967-72 [Ein Vergleich zweier Analysen der Nahrungsüberreste des Uhus (Bubo bubo L.) aus gleicher Lokalität in den Jahren 1939 und 1967-72]. Sborník Severočeského Musea, Ser. Natur. 10: 67-71. [In Czech with German 
Obuch J: Spatial and temporal changes in the diet composition of the Eurasian eagle-owl (Bubo bubo) in Slovakia comparing three historical periods

summary]

Vondráček J \& Obuch J 1980: Porovnanie potravy výra skalného (Bubo bubo) v severných Čechách a na severozápadnom Slovensku [Comparison of the food of the eagle-owl (Bubo bubo) in northern Bohemia and in northwestern Slovakia]. Ochrana prírody 1: 233-245. [In Slovak with Russian, German and English summaries]
Uttendörfer O 1939: Die Ernährung der deutschen Tagraubvögel und Eulen und ihre Bedeutung in der heimischen Natur. Verlag J. Neumann, Neudamm.

Uttendörfer O 1952: Neue Ergebnisse über die Ernährung der Greifvögel und Eulen. Ver. Eugen Ulmer, Stuttgart.

Appendix 1. Record of Eurasian eagle-owl food samples used in summaries based on area and period. Key: 1-11: areas; A: period $>70$ years, B: 70 to 30 years ago, C: < 30 years; loc.: locality, sample date.

Príloha 1. Zoznam vzoriek potravy výra skalného, použitých pri sumarizácii podla oblastí a období. Vysvetlivky: 1 - 11: oblasti; A: obdobie $>70$ rokov, B: pred 30 - 70 rokmi, C: $<30$ rokov; k.ú., lokalita, dátum zberu.

1. Orava, Orava river valley, from $450 \mathrm{~m}$ a.s.l. (Párnica) up to $900 \mathrm{~m}$ a.s.I. (Zuberec). Climate: moderately warm to moderately cool, damp.

A. Zázrivá, Havrania skala, 22.8.1995; Párnica, Bralo, 28.5.1980, 22.8.1995; Istebné, Žiar, 14.10.1996; Jasenová, Brestová, 14.10.1977; Vyšný Kubín, dolina (valley) pod Chočom, 14.10.1977; Podbiel, Červená skala (rock), 10.8.1995.

B. Párnica, Bralo, 27.5.1980; Istebné, Žiar, 11.9.1994; Žaškov, dolina Uhlisko, 18.5.1994, 8.12.2015; Dolný Kubín, Srňacie, 17.5.1994; Pucov, Zlepence, 17.5.1994; Oravský Podzámok, hradná brála (castle crag), 9.8.1995; Krivá na Orave, Ostrý vrch, 10.8.1995; Krivá na Orave, Príboj, 18.5.1995; Podbiel, Podbielska skala, 21.6.1978; Oravský Biely Potok, lom (quarry), 18.5.1994; Habovka, Blatná dolina, 11.8.1995; Zuberec, Úplazíky, 1.9.1990; Tvrdošín, Krásna Hôrka, 29.4.1995; Sedliacka Dubová, 6.6.1995.

C. Párnica, Bralo, 11.6.2015; Jasenová, Brestová, 17.5.1994, Trstená, lom, 11.8.1995, 14.6.,2009; Oravská Jasenica, Bredovka, 19.5.1994, lom, 19.5.1994; Sihelné, Hrádok, 19.5.1994.

2. Liptov, upper Váh river valley, from $500 \mathrm{~m}$ a.s.I. (Likavka) up to $750 \mathrm{~m}$ a.s.I. (Malužiná). Climate: moderately warm to moderately cool, damp.

A. Valaská Dubová, Soliská, 26.5.1977; Liptovské Revúce, Zelená dolina, 15.5.1986; Liptovská Štiavnica, Komornícka dolina, Mladucha, 22.4.2019, Četné, 21.10.2018, 13.6.2020; Demänovská dolina, Zbojnícka jaskyňa (cave), 12.9.1982; Liptovský Ján, Jánska dolina, jaskyňa Tunelová, 29.7.2008, dolina Bielo 18.9.2008, apríl 2020; Malužiná, jaskyňa Malužinské okno, 19.4.2016.

B. Ludrová, Sokolka, 11.7.1976; Lúčky, 1.7.1977; Turík, 1.5.1978; Likavka, Válovy, 13.10.1977; Kvačany, Kvačianska dolina, 1.6.1992; Liptovská Štiavnica, Komornícka dolina, Mladucha, 28.11.2018, Veža, jún 2019, Četné, 22.4.2020; Liptovský Ján, dolina Bielo, apríl' 2020; Liptovský Hrádok, Borová sihot' (watermeadows), 17.8.2017.

C. Prosiek, Prosiecka dolina, 19.7.1995; Podtureň, obora (game reserve), 26.8.2013, 17.8.2017; Liptovský Hrádok, Borová sihot', 1.5.2010; Hybe, 6.5.2009; Svarín, 1.11.2010.

3. Turiec, borders of Turčianska kotlina Basin and Vel'ká Fatra Mts and Žiar Hills, from 450 m a.s.l. (Krpel'any) up to 600 m a.s.I. (Vrícko). Climate: moderately warm, damp.

A. Necpaly, Havrania skala, 3.9. 1976; Blatnica, Zelenova skala, 2.9. 1976; Blatnica, Plešovica, hniezda (nest) 1, 2, 3, september 1976, Mošovce, Mošovské Červené, 30.5.1991; Slovenské Pravno, Sokol, 29.8.1976; Vrícko, Vrania skala, 2.7.1979.

B. Krpel'any, Sokol, 5.6.1982; Sklabinský Podzámok, Katova skala, 19.4.1992; Belá, začiatok doliny (upper valley), 19.4.1992; Necpaly, Nosáková, 3.9.1976; Blatnica, Blatnický hrad, 23.10.1975; Blatnica, Plešovica, 30.10.1977, 3.5.1990,19.8.1992, 9.6.2004; Socovce, Marské vŕšky (heights), 1982; Ondrašová, Moškovské skaly, 21.11.1976, 26.12.1979; Slovenské Pravno, Sokol, 7.4.1980, 1.11.1996.

C. Krpelany, Sokol, 6.8.1997, Belá, začiatok doliny, 7.6.1995, 31.5.1996, 30.6.2015, 27.2.2019, 21.8.2019; Necpaly, Nosáková, 25.4.1994, 31.5.1996, 11.7.1997,17.9.2017, 2.9.2019; Platnica, Blatnický hrad (castle), 29.4.1998; Blatnica, Plešovica, 22.4.1994, 9.6.1995, 11.7.1997, 1.6.2004, 8.9.2009, 15.7.2015; Mošovce, lom, 16.9.1996, 24.9.1997, 17.4.2015, 20.2.2019; Rakša, lom, 9.4.2015, 9.7.2015; Socovce, Marské vŕšky, 1995; Ondrašová, Moškovské skaly, 2.5.1994, 18.10.1996, 11.7.1997, 16.7.2006, 
Appendix 1. Continuation.

Príloha 1. Pokračovanie.

17.6.2015, Slovenské Pravno, Sokol, 21.11.1996, 11.7.1997.

4. Žilinská kotlina Basin, Váh river valley from Strečno to Bytča, Rajčianka and Varínka, from 300 m a.s.l. (Bytča) up to $550 \mathrm{~m}$ a.s.I. (Terchová). Climate: moderately warm, damp.

A. Strečno, hrad, 10.6.1977; Stráňavy, kaňon Hýrov (canyon), 28.3.1979; Višňové, Valentínov diel (part), 25.3.1978, 22.3.1979, Turie, Turská dolina, 10.8.1978; Polúvsie, Kozol, 21.6.1980; Rajecké Teplice, Skalky, september 1977, 25.7.1978; Jabloňové, dolina Javor, 5.8.1978.

B. Terchová, Tiesňavy, 13.7.1976, Strečno, hrad, 8.6.1977, 1.8.1978, 12.11.2016; Turie, Turská dolina, 10.8.1978, Porúbka, SInečné skaly, 25.6.1978; Lietava, 26.3.1978; Rajecká Lesná, Vraníny, 11.8.1978; Hričovské Podhradie, Hričovský hrad, apríl 1977; Paština Závada, 1.10.1976, Hlboké, 4.10.1978, 9.7.1982; Jabloňové, dolina Javor, 30.10.1983; Súl'ov, Roháč, 24.4.1977.

C. Krasňany, Kurská dolina, 13.11.2018; Strečno, hrad, december 2016, Stráňavy, Kojšová, 22.11.2016, Višňové, Hoblík, 23.5.2017, august 2017; Lietava, 13.11.2018.

5. Považie area, Váh river valley from Považská Teplá to Trenčín, from $210 \mathrm{~m}$ a.s.I. (Trenčín) up to $650 \mathrm{~m}$ a.s.I. (Vršatecké Podhradie). Climate: warm to moderately warm, moderately damp.

A. Považská Teplá, Vel'ký Manín, 5.10.1986; Belušské Slatiny, Ostré vŕšky, 26.2.1978, 13.3.1982; Mojtín, 2.3.1978; Pružina, Predhorie, 13.11.1976.

B. Považská Teplá, Vel'ký Manín, 19.7.1983; Uhry, Klapy, 5.11.1977; Belušské Slatiny, Ostré vŕšky, 13.3.1982, 27.11.1982; Vršatecké Podhradie, Vršatec, 26.12.1978, 6.10.2015; Čierna Lehota, 3.3.1979; Slatinka nad Bebravou, 10.12.1977, 8.1.1983; Trenčín, Skalka, 6.8.1983.

6. Ponitrie area, Nitra river valley as far as Nitra town, from $230 \mathrm{~m}$ a.s.I. (Ladice) up to $500 \mathrm{~m}$ a.s.I. (Vyšehradné). Climate: warm to moderately warm, moderately damp.

A. Malé Kršteňany, Vel'ký Vrch, 4.3.1979, 8.9.1980; Klačno, 30.9.1979; Vyšehradné, 4.12.1979.

B. Malé Kršteňany, lom, 4.3.1979; Ráztočno, 17.7.1979;Vyšehradné, 4.12.1979.

C. Malé Kršteňany, Vel'ký Vrch, 28.2.1995, 18.5.2010, 28.4.2013, 29.5.2013, 4.8.2013; Malé Kršteňany, Chalmová, 28.2.1995, 9.4.2010, 12.5.2010, 22.6.2012, 11.5.2014; Klátová Nová Ves, 28.2.1995, 18.5.2010, 2.6.2012, 19.5.2013, 14.3.2015, apríl' 2016; Opatovce nad Nitrou, 27.4.2005; Partizánske, salaš (sheepfold), 21.5.2010, 21.5.2014; Nitrianske Rudno, lom, 18.5.2012; Krásna Ves, lom, 2.6.2012, 12.5.2013, 24.5.2014, 9.5.2015; Závada, 19.5.2013, 8.5.2014; Turčianky, 19.5.2013; Horné Otrokovce, 28.6.2014, 3.5.2016; Badice, 1.5.2014; Krnča, lom, 14.3.2015, 28.2.2016; Ladice, 4.5.2015; Jelenec, 4.5.2015.

7. Pohronie area, Hron river valley, from 170 m a.s.I. (Malé Kozmálovce) up to $430 \mathrm{~m}$ a.s.I. (Nemecká). Climate: warm, moderately damp.

A. Nemecká, 27.2.2017.

B. Budča, Boky, 10.10.1975; Slovenská L’ubča, Šupínska skala, 11.7.1978; Lučatín, tábor (camp), 16.2.2017.

C. Budča, Boky, 16.4.2004; Slovenská L’ubča, Šupínska skala, 27.2.2017; Lehôtka pod Brehy, Szabova skala, októbere 1996; Horša, 9.4.2019, Malé Kozmálovce, lom, 27.2.2020.

8. Muráňska planina Plateau, southern and northern borders of the plateau, from $400 \mathrm{~m}$ a.s.l. (Muráň) up to $900 \mathrm{~m}$ a.s.l. (Telgárt). Climate: moderately warm to moderately cool, damp.

A. Pohorelská Maša, Mašianske skalky, Obuch 1978; Muráňska Huta, Tesná skala, 9.4.1979; Telgárt, Dlhý Vrch, 29.4.1979.

B. Tisovec, Hradová, 30.10.1976; Tisovec, Čertova dolinka, 27.4.1978; Muráň, Javorníčkova dolinka, 15.5.1978; Muráň, dolinka Bodolová, 1.8.1980; Zlatno, dolina Zlatnica, 25.10.2001; Telgárt, Homol'a, 13.6.1979, 1.10.2001.

C. Zlatno, dolina Zlatnica, 25.10.2001, 13.8.2003; Valkovňa, Zlatnianske skaly, 29.6.2000, 17.8.2003, 2.8.2005, 17.5.2017.

9. Spiš region, Slovenský raj National Park, Poprad, Hornád and Hnilec river valleys, from 430 m a.s.l. (Žehra) up to 900 m a.s.I. (Ždiar). Climate: moderately warm to moderately cool, moderately damp to damp.

A. Stratená, Stratenský tunel, 9.7.1990; Vernár, 12.5.2014.

B. Vernár, Vernárska tiesňava (ravine), 26.10.1994; Spišské Podhradie, Dreveník, 16.9.1976; Ždiar, Monkova dolina, 31.7 .1997$.

C. Žehra, Dreveník, 8.4.2014, 14.7.2014; Haligovce, Haligovské skaly, 23.9.2003.

10. Rimavská kotlina Basin, borders of Cerová and Revúcka Uplands, from 190 m a.s.I. (Bretka) up to 280 m a.s.l. (Šiatorská Bukovinka). Climate: warm, moderately damp.

B. Belina, Belinská skala, apríl 1981; Bretka, Prielom Muráňky, 10.7.1992.

C. Belina, Belinská skala, 27.6.1995; Hrušov, lom (quarry), 9.4.1998; Drienčany, lom, 2.6.1995, 20.6.1996, 10.9.1997, 23.9.1998, 14.4.1999; Gemerské Dechtáre, Bagova skala, 21.4.1998, 2.6.2000, 20.9.2006; Šiatorská Bukovinka, lom, 22.4.1998; Bulhary, lom, 19.9.2006; Husiná, lom, 19.9.2006; Vel'ké Dravce, 19.9.2006.

11. Slovenský kras Karst area, lower borders of karst plateaux, from $180 \mathrm{~m}$ a.s.I. (Drienovec) up to $260 \mathrm{~m}$ a.s.I. (Jasov). Climate: warm, moderately damp.

A. Zádiel, Zádielská dolina, 19.9.1976.

B. Zádiel, Zádielská dolina, 19.9.1976; Jasov, jaskyňa, 19.9.1976, 18.9.1991; Debrad', Hatiny, 25.6.1977, 18.9.1991; Hrhov, Pod Kresaným, 29.10.1981.

C. Zádiel, Zádielská dolina, 12.5.1994; Debrad', Hatiny, 1996; Hrhov, Dolný Vrch, 30.3.2015; Drienovec, lom, 11.9.1997; Plešivec, lom, 27.8.1996. 
Obuch J: Spatial and temporal changes in the diet composition of the Eurasian eagle-owl (Bubo bubo) in Slovakia comparing three historical periods

Appendix 2. Comparison of Eurasian eagle-owl diets over three historical periods in the Orava region.

Príloha 2. Porovnanie potravy výra skalného z troch období na Orave.

\begin{tabular}{|c|c|c|c|c|c|c|c|c|}
\hline \multirow{2}{*}{$\begin{array}{l}\text { obdobie (roky pred) / period (years ago) } \\
\text { period No. / obdobie č. } \\
\text { taxa / taxón } \\
\text { Rana temporaria }(\mathrm{n} / \mathrm{ks})\end{array}$} & \multicolumn{2}{|c|}{$\begin{array}{l}A:>70 \\
1\end{array}$} & \multicolumn{2}{|c|}{$\begin{array}{l}\text { B: } 30-70 \\
2\end{array}$} & \multicolumn{2}{|c|}{$\begin{array}{l}C:<30 \\
3\end{array}$} & $\Sigma$ & $\%$ \\
\hline & $1+$ & 2369 & $1-$ & 1733 & $2-$ & 181 & 4283 & 28.83 \\
\hline$\%$ & & 42.42 & & 22.53 & & 11.45 & & \\
\hline Apodemus sylvaticus & $1+$ & 349 & $1-$ & 168 & $2-$ & 13 & 530 & 3.57 \\
\hline Apodemus microps & $1+$ & 51 & 3- & 0 & $1-$ & 0 & 51 & 0.34 \\
\hline Apodemus agrarius & $1+$ & 85 & $1-$ & 34 & $1-$ & 3 & 122 & 0.82 \\
\hline Mus musculus & $1+$ & 85 & 2- & 11 & $1-$ & 1 & 97 & 0.65 \\
\hline Coloeus monedula & $1+$ & 27 & $1-$ & 16 & & 3 & 46 & 0.31 \\
\hline Turdus merula & $1-$ & 2 & $1+$ & 28 & & 4 & 34 & 0.23 \\
\hline Turdus philomelos & $1-$ & 22 & $1+$ & 57 & & 5 & 84 & 0.57 \\
\hline Cypriniformes sp. & $1-$ & 1 & $1+$ & 17 & & & 18 & 0.12 \\
\hline Arvicola amphibius & $1-$ & 304 & $1+$ & 1184 & $1+$ & 228 & 1716 & 11.55 \\
\hline Erinaceus roumanicus & $1-$ & 21 & & 42 & $2+$ & 41 & 104 & 0.70 \\
\hline Rattus norvegicus & $1-$ & 74 & & 196 & $1+$ & 96 & 366 & 2.46 \\
\hline Microtus arvalis (n/ks) & $1-$ & 1620 & & 3212 & $1+$ & 742 & 5574 & 37.52 \\
\hline$\%$ & & 29.01 & & 41.76 & & 46.93 & & \\
\hline Sciurus vulgaris & & 10 & & 18 & $1+$ & 9 & 37 & 0.25 \\
\hline Mustela nivalis & & 7 & & 15 & $1+$ & 8 & 30 & 0.20 \\
\hline Columba livia dom. & $2-$ & 3 & & 31 & $1+$ & 15 & 49 & 0.33 \\
\hline Perdix perdix & & 24 & & 42 & $1+$ & 19 & 85 & 0.57 \\
\hline Buteo buteo & $1-$ & 3 & & 9 & $1+$ & 9 & 21 & 0.14 \\
\hline Asio otus & $1-$ & 10 & & 37 & $1+$ & 17 & 64 & 0.43 \\
\hline Garrulus glandarius & $1-$ & 5 & & 18 & $1+$ & 10 & 33 & 0.22 \\
\hline Turdus pilaris & $1-$ & 7 & & 31 & $1+$ & 19 & 57 & 0.38 \\
\hline Corvus cornix + frugilegus & $1-$ & 45 & & 100 & & 17 & 162 & 1.09 \\
\hline Turdus viscivorus & $1-$ & 3 & & 14 & & 4 & 21 & 0.14 \\
\hline Sturnus vulgaris & $1-$ & 0 & & 7 & & 4 & 11 & 0.07 \\
\hline Anas platyrhynchos & $1-$ & 0 & & 8 & & 5 & 13 & 0.09 \\
\hline Apodemus flavicollis & & 159 & & 185 & 2- & 9 & 353 & 2.38 \\
\hline Lepus europaeus & & 24 & & 49 & & 13 & 86 & 0.58 \\
\hline Talpa europaea & & 21 & & 37 & & 4 & 62 & 0.42 \\
\hline Alauda arvensis & & 22 & & 26 & & 4 & 52 & 0.35 \\
\hline Muscardinus avellanarius & & 8 & & 23 & & 2 & 33 & 0.22 \\
\hline Coturnix coturnix & & 17 & & 12 & & 4 & 33 & 0.22 \\
\hline Myodes glareolus & & 13 & & 15 & & 3 & 31 & 0.21 \\
\hline Scolopax rusticola & & 8 & & 19 & & 3 & 30 & 0.20 \\
\hline Falco tinnunculus & & 8 & & 15 & & 4 & 27 & 0.18 \\
\hline Microtus agrestis & & 10 & & 10 & & 5 & 25 & 0.17 \\
\hline Turdus torquatus & & 10 & & 10 & & 3 & 23 & 0.15 \\
\hline Strix aluco & & 10 & & 9 & & 2 & 21 & 0.14 \\
\hline Terricola subterraneus & & 5 & & 16 & & & 21 & 0.14 \\
\hline Glis glis & & 5 & & 12 & & 4 & 21 & 0.14 \\
\hline Columba palumbus & & 4 & & 15 & & & 19 & 0.13 \\
\hline Pica pica & & 4 & & 9 & & 4 & 17 & 0.11 \\
\hline Salmo trutta & & 3 & & 12 & & 1 & 16 & 0.11 \\
\hline Vulpes vulpes & & 4 & & 6 & & 6 & 16 & 0.11 \\
\hline
\end{tabular}


Appendix 2. Continuation.

Príloha 2. Pokračovanie.

\begin{tabular}{|c|c|c|c|c|c|}
\hline $\begin{array}{l}\text { obdobie (roky pred) / period (years ago) } \\
\text { period No. / obdobie č. } \\
\text { taxa / taxón }\end{array}$ & $\begin{array}{l}A:>70 \\
1\end{array}$ & $\begin{array}{l}\text { B: } 30-70 \\
2\end{array}$ & $\begin{array}{l}\mathrm{C}:<30 \\
3\end{array}$ & $\Sigma$ & $\%$ \\
\hline Dryomys nitedula & 5 & 10 & & 15 & 0.10 \\
\hline Mustela erminea & 1 & 7 & 5 & 13 & 0.09 \\
\hline Sorex araneus & 3 & 8 & 2 & 13 & 0.09 \\
\hline Neomys fodiens & 7 & 6 & & 13 & 0.09 \\
\hline Sicista betulina & 1 & 8 & 2 & 11 & 0.07 \\
\hline Emberiza citrinella & 2 & 8 & 1 & 11 & 0.07 \\
\hline Mammalia & 2896 & 5296 & 1200 & 9392 & 63.21 \\
\hline Aves & 306 & 625 & 191 & 1122 & 7.55 \\
\hline Amphibia, Reptilia, Pisces & 2381 & 1768 & 190 & 4339 & 29.20 \\
\hline Evertebrata & 2 & 3 & 0 & 5 & 0.03 \\
\hline$\sum$ & 5585 & 7692 & 1581 & 14,858 & 100.00 \\
\hline Diversity Index H' & 1.94 & 2.04 & 2.16 & 2.1 & \\
\hline
\end{tabular}

Others prey species (Period no.-no. of items): Ostatné druhy (Obdobie č.-počet):

Sorex minutus (2-2), Neomys anomalus (1-1; 2-1), Crocidura leucodon (1-1), Crocidura suaveolens (1-1; 2-1), Myotis nattereri (21), Myotis myotis (1-2; 2-3), Myotis blythii (1-1), Vespertilio murinus (1-1; 2-1), Eptesicus serotinus (1-5; 3-1), Nyctalus noctula (21), Pipistrellus pipistrellus (3-1), Plecotus auritus (2-3), Eliomys quercinus (1-4; $2-1)$, Micromys minutus (1-1; 2-1; 3-1), Ondatra zibethicus (2-5), Terricola tatricus (1-3), Chionomys nivalis (2-3), Martes foina (1-1), Mustela putorius (1-2; 2-1), Felis catus dom. (1-1), Cervus elaphus (3-1), Tachybaptus ruficollis (2-1), Ixobrychus minutus (2-1), Anas crecca (2-2), Anas querquedula (1-1; 23; 3-1), Aythya fuligula (3-2), Anatidae sp. (3-1), Accipiter gentilis (1-1), Falco subbuteo (3-2), Tetrastes bonasia (1-3; 2-3; 3-1), Lyrurus tetrix (2-1), Tetrao urogallus (2-2), Galliformes sp. (1-1; 3-1), Rallus aquaticus (1-2; 2-1), Porzana porzana (1-1; 2-1), Crex crex (1-2; 2-4; 3-1), Gallinula chloropus (1-1; 2-3; 3-2), Fulica atra (1-1), Charadrius dubius (2-2), Vanellus vanellus (2-5; 34), Actitis hypoleucos (1-5; 3-1), Philomachus pugnax (1-1; 2-1), Gallinago gallinago (2-1), Limicolae sp. (2-1), Columba oenas (15), Streptopelia decaocto (2-6; 3-3), Streptopelia turtur (1-2; 2-3), Cuculus canorus (1-1; 3-2), Tyto alba (1-1; 2-1), Bubo bubo (1$2 ; 2-3)$, Aegolius funereus (1-2; 2-2; 3-1), Athene noctua (1-1), Caprimulgus europaeus (2-1; 3-1), Dryocopus martius (1-1; 2-1), Jynx torquilla (1-1), Lullula arborea (1-2; 2-2), Galerida cristata (1-1; 2-1), Hirundo rustica (3-1), Delichon urbicum (1-1; 2-6; 3-1), Riparia riparia (2-2), Anthus trivialis (1-3; 2-3), Bombycilla garrulus (2-1), Lanius collurio (1-7; 2-3), Sylvia atricapilla (1-1), Regulus sp. (2-1), Muscicapa striata (1-1), Erithacus rubecula (2-7; 3-1), Turdus iliacus (2-2), Parus major (2-1), Cyanistes caeruleus (2-1; 3-1), Emberiza calandra (2-1), Fringilla coelebs (1-2; 2-4; 3-2), Carduelis carduelis (2-3; 3-2), Carduelis cannabina (2-1), Carduelis chloris (1-1), Pyrrhula pyrrhula (2-1), Coccothraustes coccothr. (1-3), Serinus serinus (1-1), Loxia curvirostra (1-1; 2-1), Fringillidae sp. (1-1), Passer domesticus (1-1; 2-3; 3-2), Nucifraga caryocatactes (1-2; 2-4), Passeriformes sp. (1-5; 2-5; 3-1), Aves sp. (1-1; 2-1), Aves sp.juv. (1-1; 2-1; 3-1), Bombina sp. (2-1), Bufo bufo (1-1; 3-2), Pelophylax cf. esculentus (1-2), Lacerta agilis (1-4; 2-1; 3-2), Lacerta sp. (2-2; 3-1), Colubridae sp. (3-1), Pisces sp. (1-1; 2-2; 3-2), Coleoptera sp. (2-1), Limacidae sp. (1-2; 2-2).

Note: Numerical data in the table are given in absolute values, and positive and negative deviations (e.g $1+, 2+, 1$-, 2-) are marked deviations from the mean (MDFM, Obuch 2001 ) for the species in these samples (see Methods).

Poznámka: Číselné hodnoty v tabulke sú uvedené v absolútnych hodnotách, kladné a záporné odchýlky (1+, 2+, 1 -, 2- a podobne) sú výrazné odchýlky od priemeru (MDFM, Obuch 2001 ) druhov vo vzorkách (pozri Metodiku). 
Obuch J: Spatial and temporal changes in the diet composition of the Eurasian eagle-owl (Bubo bubo) in Slovakia comparing three historical periods

Appendix 3. Comparison of Eurasian eagle-owl diets over three historical periods in the Liptov region.

Príloha 3. Porovnanie potravy výra skalného z troch období na Liptove.

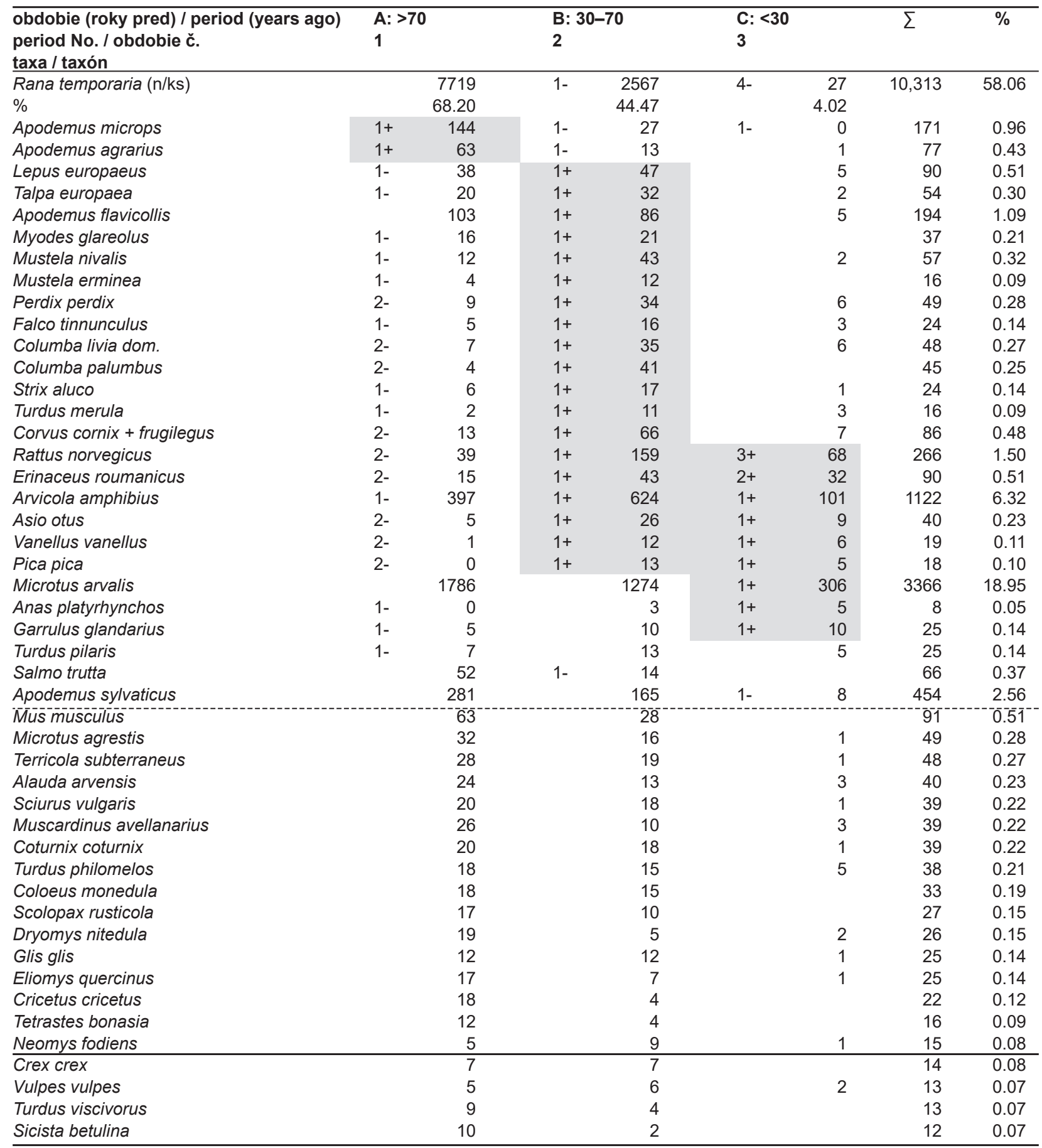


Appendix 3. Continuation.

Príloha 3. Pokračovanie.

\begin{tabular}{|c|c|c|c|c|c|}
\hline $\begin{array}{l}\text { obdobie (roky pred) / period (years ago) } \\
\text { period No. / obdobie č. } \\
\text { taxa / taxón }\end{array}$ & $\begin{array}{l}A:>70 \\
1\end{array}$ & $\begin{array}{l}\text { B: } 30-70 \\
2\end{array}$ & $\begin{array}{l}C:<30 \\
3\end{array}$ & $\Sigma$ & $\%$ \\
\hline Accipiter gentilis & 8 & 4 & & 12 & 0.07 \\
\hline Micromys minutus & 9 & 2 & & 11 & 0.06 \\
\hline Delichon urbicum & 8 & 2 & 1 & 11 & 0.06 \\
\hline Bufo bufo & 8 & 3 & & 11 & 0.06 \\
\hline Mammalia & 3212 & 2717 & 547 & 6476 & 36.46 \\
\hline Aves & 294 & 464 & 91 & 849 & 4.78 \\
\hline Amphibia, Reptilia, Pisces & 7808 & 2591 & 33 & 10,432 & 58.73 \\
\hline Evertebrata & 4 & 1 & 0 & 5 & 0.03 \\
\hline$\Sigma$ & 11,318 & 5773 & 671 & 17,762 & 100.00 \\
\hline Diversity Index H' & 1.37 & 2.1 & 2.19 & 1.73 & \\
\hline
\end{tabular}

Others prey species (Period no.-no. of items): Ostatné druhy (Obdobie č.-počet):

Sorex araneus (1-3; 2-5; 3-1), Sorex minutus (2-3), Neomys anomalus (1-1; 2-1), Crocidura suaveolens (1-3; 2-2), Myotis mystacinus (1-1), Myotis brandtii (2-1), Myotis bechsteinii (1-1; 2-1), Myotis myotis (1-1; 2-1), Vespertilio murinus (1-2; 2-3), Eptesicus serotinus (1-3; 2-6), Nyctalus noctula (1-1; 2-1), Pipistrellus pipistrellus (2-3), Barbastella barbastellus (1-2; 2-1), Plecotus auritus (1-1), Rattus rattus (1-1), Ondatra zibethicus (2-1), Chionomys nivalis (1-6), Canis familiaris (3-1), Martes sp. (21), Mustela putorius (1-1; 2-2), Felis catus dom. (2-1; 3-1), Sus scrofa (1-2), Capreolus capreolus (1-1), Ovis ammon aries (3-1), Tachybaptus ruficollis (2-1; 3-2), Anas crecca (2-1), Anatidae sp. (2-1), Accipiter nisus (1-4; 2-1), Buteo buteo (2-4; 3-2), Pernis apivorus (2-1), Aquila pomarina (3-1), Falco peregrinus (1-1; 2-1), Lyrurus tetrix (1-4), Tetrao urogallus (1-1; 2-2), Phasianus colchicus (2-3), Gallus gallus dom. (1-2), Rallus aquaticus (1-1; 2-1), Porzana porzana (1-1), Gallinula chloropus (3-1), Charadrius dubius (2-1), Tringa glareola (1-1), Actitis hypoleucos (1-4; 2-3), Gallinago gallinago (1-3; 2-1), Gallinago sp. (2-1), Chlidonias niger (1-1), Columba oenas (1-5), Streptopelia decaocto (2-5), Streptopelia turtur (1-2; 2-1), Cuculus canorus (1-1; 2-1), Bubo bubo (1-3; 2-1), Asio flammeus (1-1; 2-1), Aegolius funereus (1-5; 2-3), Athene noctua (1-1), Strix uralensis (3-3), Caprimulgus europaeus (1-2; 2-1), Dryocopus martius (2-2), Dendrocopos major (2-2), Dendrocopos medius (2-1), Jynx torquilla (3-1), Lullula arborea (1-2; 2-1), Hirundo rustica (1-3), Anthus trivialis (2-1), Anthus spinoletta (1-1), Motacilla alba (1-1; 2-1), Lanius minor (11), Lanius collurio (1-6; 2-1), Acrocephalus palustris (2-1), Sylvia atricapilla (1-1), Phylloscopus sibilatrix (1-1), Sylviidae sp. (1-2), Turdus torquatus (1-1; 2-3; 3-1), Turdus iliacus (1-1), Parus major (1-1), Cinclus cinclus (1-1), Emberiza citrinella (1-4; 2-1; 3-1), Emberiza calandra (1-1), Emberiza sp. (1-1), Fringilla coelebs (1-3; 2-4), Carduelis carduelis (1-1; 3-1), Carduelis cannabina (11), Carduelis chloris (2-1), Pyrrhula pyrrhula (1-1), Coccothraustes coccothr. (1-1; 2-2), Loxia curvirostra (1-1; 2-3), Passer domesticus (1-1), Passer montanus (2-1), Sturnus vulgaris (2-5), Nucifraga caryocatactes (2-3), Corvus corax (1-1; 2-1; 3-2), Corvus cornix (1-1), Passeriformes sp. (1-3; 2-5), Passeriformes sp. juv (1-1), Aves sp. (2-1), Aves sp .juv. (1-3), Bombina variegata (1-2), Bufotes viridis (1-2), Bufo sp. (1-2), Hyla arborea (1-2), Lacerta agilis (1-1; 2-1), Natrix natrix (1-1), Colubridae sp. (2-1), Cypriniformes sp. (1-1; 2-1; 3-6), Pisces sp. (1-18; 2-4), Coleoptera sp. (1-1; 2-1), Limacidae sp. (1-3). 
Obuch J: Spatial and temporal changes in the diet composition of the Eurasian eagle-owl (Bubo bubo) in Slovakia comparing three historical periods

Appendix 4. Comparison of Eurasian eagle-owl diets over three historical periods in the Turiec area.

Príloha 4. Porovnanie potravy výra skalného z troch období v Turci.

\begin{tabular}{|c|c|c|c|c|c|c|c|c|}
\hline \multirow{2}{*}{$\begin{array}{l}\text { obdobie (roky pred) / period (years ago) } \\
\text { period No. / obdobie č. } \\
\text { taxa / taxón } \\
\text { Rana temporaria }(\mathrm{n} / \mathrm{ks})\end{array}$} & \multicolumn{2}{|c|}{$\begin{array}{l}A:>70 \\
1\end{array}$} & \multicolumn{2}{|c|}{$\begin{array}{l}\text { B: } 30-70 \\
2\end{array}$} & \multicolumn{2}{|c|}{$\begin{array}{l}C:<30 \\
3\end{array}$} & $\Sigma$ & $\%$ \\
\hline & $1+$ & 3915 & & 2124 & $1-$ & 1055 & 7094 & 31.57 \\
\hline$\%$ & & 40 & & 29.4 & & 19.32 & & \\
\hline Pelophylax cf. esculentus & $1+$ & 17 & & 2 & $1-$ & 0 & 19 & 0.08 \\
\hline Pelobates fuscus & $1+$ & 43 & $1-$ & 3 & $2-$ & 0 & 46 & 0.20 \\
\hline Apodemus microps & $1+$ & 134 & 2- & 14 & 2- & 7 & 155 & 0.69 \\
\hline Apodemus sylvaticus & $1+$ & 717 & $1-$ & 218 & $1-$ & 153 & 1088 & 4.84 \\
\hline Mus cf. musculus & $1+$ & 151 & & 74 & $1-$ & 40 & 265 & 1.18 \\
\hline Galerida cristata & $1+$ & 23 & $1-$ & 0 & $1-$ & 0 & 23 & 0.10 \\
\hline Mustela nivalis & $1-$ & 47 & $1+$ & 80 & $1-$ & 24 & 151 & 0.67 \\
\hline Salmo trutta & $1-$ & 20 & $1+$ & 43 & & 12 & 75 & 0.33 \\
\hline Erinaceus roumanicus & $1-$ & 35 & $1+$ & 70 & $1+$ & 58 & 163 & 0.73 \\
\hline Rattus norvegicus & $1-$ & 137 & $1+$ & 215 & $1+$ & 189 & 541 & 2.41 \\
\hline Arvicola amphibius & $1-$ & 189 & $1+$ & 360 & $1+$ & 237 & 786 & 3.50 \\
\hline Apodemus flavicollis & & 445 & $1-$ & 254 & $1+$ & 341 & 1040 & 4.63 \\
\hline Myodes glareolus & & 68 & $1-$ & 32 & $1+$ & 89 & 189 & 0.84 \\
\hline Columba livia dom. & $2-$ & 8 & & 34 & $1+$ & 73 & 115 & 0.51 \\
\hline Streptopelia decaocto & $2-$ & 0 & & 6 & $1+$ & 13 & 19 & 0.08 \\
\hline Perdix perdix & $1-$ & 36 & & 57 & $1+$ & 48 & 141 & 0.63 \\
\hline Falco tinnunculus & $1-$ & 12 & $1-$ & 14 & $1+$ & 39 & 65 & 0.29 \\
\hline Buteo buteo & $1-$ & 7 & & 8 & $1+$ & 15 & 30 & 0.13 \\
\hline Asio otus & $1-$ & 22 & & 37 & $1+$ & 54 & 113 & 0.50 \\
\hline Anas platyrhynchos & $1-$ & 4 & & 8 & $1+$ & 22 & 34 & 0.15 \\
\hline Gallinula chloropus & $1-$ & 0 & & 5 & $1+$ & 12 & 17 & 0.08 \\
\hline Erithacus rubecula & & 1 & & & $1+$ & 7 & 8 & 0.04 \\
\hline Turdus philomelos & $2-$ & 8 & & 24 & $2+$ & 67 & 99 & 0.44 \\
\hline Turdus merula & $1-$ & 7 & & 11 & $1+$ & 31 & 49 & 0.22 \\
\hline Turdus pilaris & $1-$ & 1 & & 9 & $1+$ & 13 & 23 & 0.10 \\
\hline Pica pica & $1-$ & 14 & & 14 & $1+$ & 24 & 52 & 0.23 \\
\hline Garrulus glandarius & $1-$ & 5 & & 12 & $1+$ & 23 & 40 & 0.18 \\
\hline Lacerta agilis & $1-$ & 0 & & 3 & $1+$ & 7 & 10 & 0.04 \\
\hline Lepus europaeus & $1-$ & 29 & & 37 & & 25 & 91 & 0.40 \\
\hline Mustela erminea & & 18 & & 16 & $1-$ & 4 & 38 & 0.17 \\
\hline Microtus arvalis (n/ks) & & 3157 & & 3005 & & 2426 & 8588 & 38.22 \\
\hline$\%$ & & 32.26 & & 41.6 & & 44.42 & & \\
\hline Corvus cornix + frugilegus & & 96 & & 81 & & 54 & 231 & 1.03 \\
\hline Coturnix coturnix & & 49 & & 29 & & 22 & 100 & 0.44 \\
\hline Sciurus vulgaris & & 34 & & 33 & & 21 & 88 & 0.39 \\
\hline Talpa europaea & & 31 & & 30 & & 13 & 74 & 0.33 \\
\hline Alauda arvensis & & 17 & & 16 & & 19 & 52 & 0.23 \\
\hline Vanellus vanellus & & 14 & & 18 & & 15 & 47 & 0.21 \\
\hline Strix aluco & & 14 & & 14 & & 14 & 42 & 0.19 \\
\hline Eliomys quercinus & & 21 & & 13 & & 6 & 40 & 0.18 \\
\hline Glis glis & & 15 & & 11 & & 6 & 32 & 0.14 \\
\hline Scolopax rusticola & & 12 & & 8 & & 10 & 30 & 0.13 \\
\hline Apodemus agrarius & & 13 & & 10 & & 5 & 28 & 0.12 \\
\hline Crex crex & & 11 & & 10 & & 3 & 24 & 0.11 \\
\hline Micromys minutus & & 9 & & 4 & & 9 & 22 & 0.10 \\
\hline Vulpes vulpes & & 6 & & 8 & & 6 & 20 & 0.09 \\
\hline Coloeus monedula & & 7 & & 5 & & 6 & 18 & 0.08 \\
\hline Terricola subterraneus & & 5 & & 6 & & 5 & 16 & 0.07 \\
\hline Muscardinus avellanarius & & 9 & & 3 & & 3 & 15 & 0.07 \\
\hline
\end{tabular}


Appendix 4. Continuation.

Príloha 4. Pokračovanie.

\begin{tabular}{|c|c|c|c|c|c|}
\hline $\begin{array}{l}\text { obdobie (roky pred) / period (years ago) } \\
\text { period No. / obdobie č. } \\
\text { taxa / taxón }\end{array}$ & $\begin{array}{l}A:>70 \\
1\end{array}$ & $\begin{array}{l}\text { B: } 30-70 \\
2\end{array}$ & $\begin{array}{l}C:<30 \\
3\end{array}$ & $\Sigma$ & $\%$ \\
\hline Microtus agrestis & 3 & 5 & 6 & 14 & 0.06 \\
\hline Anas querquedula & 5 & 5 & 4 & 14 & 0.06 \\
\hline Myotis myotis & 7 & 4 & 2 & 13 & 0.06 \\
\hline Sturnus vulgaris & 5 & 2 & 6 & 13 & 0.06 \\
\hline Anas crecca & 7 & 1 & 4 & 12 & 0.05 \\
\hline Cricetus cricetus & 6 & 4 & & 10 & 0.04 \\
\hline Mammalia & 5330 & 4527 & 3690 & 13,547 & 60.28 \\
\hline Aves & 452 & 505 & 681 & 1638 & 7.29 \\
\hline Amphibia, Reptilia, Pisces & 4005 & 2189 & 1088 & 7282 & 32.4 \\
\hline Evertebrata & 0 & 3 & 2 & 5 & 0.02 \\
\hline$\Sigma$ & 9787 & 7224 & 5461 & 22,472 & 100.00 \\
\hline Diversity Index H' & 1.91 & 2.03 & 2.25 & 2.09 & \\
\hline
\end{tabular}

Others prey species (Period no.-no. of items): Ostatné druhy (Obdobie č.-počet):

Sorex araneus (3-5; 2-4; 1-2), Sorex minutus (1-2), Neomys anomalus (3-3; 1-1), Neomys fodiens (3-7; 2-3; 1-1), Crocidura leucodon (3-2), Crocidura suaveolens (2-2; 1-2), Rhinolophus ferrumequinum (2-1), Rhinolophus hipposideros (2-1), Myotis mystacinus (2-1), Myotis bechsteinii (3-2; 2-1), Vespertilio murinus (3-6; 2-2; 1-1), Eptesicus serotinus (3-2; 2-2), Eptesicus nilssonii (1-1), Nyctalus noctula (3-3), Pipistrellus pipistrellus (3-5), Barbastella barbastellus (3-4), Sicista betulina (3-2), Rattus rattus (3-1), Ondatra zibethicus (2-4; 1-2), Martes sp. (3-1), Mustela vison (1-1), Felis catus dom. (1-2), Sus scrofa (3-1), Tachybaptus ruficollis (3-1; 2-1; 1-3), Anas acuta (1-1), Anatidae sp. (3-4), Accipiter gentilis (2-3; 1-5), Accipiter nisus (3-2; 1-4), Aquila sp. (1-1), Accipitridae sp. (3-1), Falco sp. (3-3), Tetrastes bonasia (2-1; 1-1), Phasianus colchicus (3-1; 2-3), Gallus gallus dom. (2-1), Rallus aquaticus (3-1; 2-3; 1-5), Porzana porzana (3-2; 2-2; 1-4), Zapornia parva (2-1), Fulica atra (2-2; 1-4), Rallidae sp. (3-1), Tringa glareola (2-3), Tringa sp. (3-2), Actitis hypoleucos (3-1; 2-1; 1-3), Philomachus pugnax (3-2), Gallinago gallinago (2-2), Gallinago sp. (2-1; 1-2), Chroicocephalus ridibundus (1-3), Sterna hirundo (1-1), Chlidonias niger (2-1), Columba oenas ( $3-4 ; 2-1 ; 1-2)$, Columba palumbus (3-4; 2-5; 1-2), Columba sp. (2-1), Streptopelia turtur (2-1; 1-4), Cuculus canorus (3-2; $2-1$; 1-4), Bubo bubo (2-3; 1-2), Asio flammeus (2-1), Aegolius funereus (3-2), Athene noctua (3-2), Caprimulgus europaeus (3-1; 2-2), Dryocopus martius (2-1; 1-1), Lullula arborea (2-1; 1-2), Hirundo rustica (2-1), Delichon urbicum (2-1; 1-1), Motacilla alba (32), Lanius excubitor (1-1), Lanius minor (3-2), Lanius collurio (1-1), Hippolais icterina (3-2), Sylvia atricapilla (1-2), Saxicola rubetra (2-1), Phoenicurus ochruros (1-4), Turdus iliacus (2-1), Turdus viscivorus (3-3; 2-1; 1-4), Turdus sp. (2-2), Parus major (3-1), Sitta europaea (2-1), Cinclus cinclus (1-1), Emberiza citrinella (3-2; 2-2; 1-4), Emberiza calandra (3-1), Fringilla coelebs (1-2), Carduelis carduelis (3-3; 2-1), Carduelis cannabina (2-1), Coccothraustes coccothr. (3-2; 2-1), Serinus serinus (2-1), Passer domesticus (2-4), Nucifraga caryocatactes (2-2; 1-2), Corvus corax (2-1; 1-1), Passeriformes sp. (3-12; 2-12; 1-3), Aves sp. (2-1; 1-1), Aves sp. juv. (3-1; 2-1; 1-2), Bufo bufo (2-4), Bufotes viridis (2-1; 1-1), Hyla arborea (3-2), Pelophylax ridibundus (2-1), Lacerta muralis (2-2; 1-1), Zootoca vivipara (1-2), Natrix natrix (2-1), Cypriniformes sp. (3-8; 2-5; 1-10), Coleoptera sp. (2-3; 1-2). 
Obuch J: Spatial and temporal changes in the diet composition of the Eurasian eagle-owl (Bubo bubo) in Slovakia comparing three historical periods

Appendix 5. Comparison of Eurasian eagle-owl diets over three historical periods in the Žilinská kotlina Basin.

Príloha 5. Porovnanie potravy výra skalného z troch období v Žilinskej kotline.

\begin{tabular}{|c|c|c|c|c|c|c|c|c|}
\hline $\begin{array}{l}\text { obdobie (roky pred) / period (years ago) } \\
\text { period No. / obdobie č. } \\
\text { taxa / taxón }\end{array}$ & & & $\begin{array}{l}\text { B: } \\
2\end{array}$ & & $\begin{array}{l}\text { C: } \\
3\end{array}$ & & $\Sigma$ & $\%$ \\
\hline Apodemus microps & $1+$ & 258 & $2-$ & 18 & $2-$ & 0 & 276 & 1.37 \\
\hline Rana temporaria (n/ks) & & 6334 & $1-$ & 942 & $2-$ & 78 & 7354 & 36.60 \\
\hline$\%$ & & 43.48 & & 20.46 & & 8.47 & & \\
\hline Pelophylax cf. esculentus & & 109 & $1-$ & 13 & $1-$ & 1 & 123 & 0.61 \\
\hline Mus cf. musculus & & 189 & $1-$ & 27 & $1-$ & 4 & 220 & 1.09 \\
\hline Terricola subterraneus & & 101 & $1-$ & 18 & $1-$ & 0 & 119 & 0.59 \\
\hline Apodemus sylvaticus & & 999 & & 247 & $2-$ & 11 & 1257 & 6.26 \\
\hline Microtus arvalis & & 4248 & & 1642 & $1-$ & 215 & 6105 & 30.38 \\
\hline Perdix perdix & $2-$ & 51 & $2+$ & 145 & $1-$ & 2 & 198 & 0.99 \\
\hline Phasianus colchicus & $1-$ & 8 & $1+$ & 16 & & 1 & 25 & 0.12 \\
\hline Sciurus vulgaris & $1-$ & 13 & $1+$ & 34 & & 4 & 51 & 0.25 \\
\hline Mustela nivalis & & 52 & $1+$ & 32 & & 3 & 87 & 0.43 \\
\hline Corvus cornix + frugilegus & $1-$ & 85 & $1+$ & 68 & & 5 & 158 & 0.79 \\
\hline Lanius collurio & $1-$ & 2 & $1+$ & 8 & & & 10 & 0.05 \\
\hline Erinaceus roumanicus & $2-$ & 38 & $2+$ & 111 & $2+$ & 28 & 177 & 0.88 \\
\hline Lepus europaeus & $1-$ & 88 & $1+$ & 118 & $1+$ & 29 & 235 & 1.17 \\
\hline Arvicola amphibius & $1-$ & 278 & $1+$ & 243 & $1+$ & 40 & 561 & 2.79 \\
\hline Asio otus & $2-$ & 17 & $1+$ & 42 & $1+$ & 10 & 69 & 0.34 \\
\hline Rattus norvegicus & $1-$ & 126 & $1+$ & 188 & $2+$ & 49 & 363 & 1.81 \\
\hline Columba livia dom. & $2-$ & 19 & $1+$ & 43 & $3+$ & 46 & 108 & 0.54 \\
\hline Apodemus flavicollis & $1-$ & 405 & & 188 & $3+$ & 202 & 795 & 3.96 \\
\hline Apodemus agrarius & & 105 & $1-$ & 15 & $2+$ & 28 & 148 & 0.74 \\
\hline Myodes glareolus & & 130 & & 35 & $2+$ & 33 & 198 & 0.99 \\
\hline Falco tinnunculus & $1-$ & 15 & & 8 & $2+$ & 12 & 35 & 0.17 \\
\hline Turdus pilaris & $1-$ & 8 & & 8 & $2+$ & 17 & 33 & 0.16 \\
\hline Turdus philomelos & $1-$ & 29 & & 20 & $1+$ & 10 & 59 & 0.29 \\
\hline Turdus merula & $1-$ & 6 & & 11 & $1+$ & 9 & 26 & 0.13 \\
\hline Streptopelia decaocto & $1-$ & 1 & & 4 & & 3 & 8 & 0.04 \\
\hline Anas platyrhynchos & $1-$ & 4 & & 7 & & 2 & 13 & 0.06 \\
\hline Sturnus vulgaris & $1-$ & 5 & & 7 & & 3 & 15 & 0.07 \\
\hline Alauda arvensis & & 62 & $1-$ & 8 & & 1 & 71 & 0.35 \\
\hline Salmo trutta & & 24 & $1-$ & 0 & & & 24 & 0.12 \\
\hline Cóturnix coturnix & & 93 & & 22 & & 3 & $118^{-}$ & $0.59^{-}$ \\
\hline Talpa europaea & & 90 & & 22 & & 4 & 116 & 0.58 \\
\hline Strix aluco & & 39 & & 19 & & 4 & 62 & 0.31 \\
\hline Scolopax rusticola & & 43 & & 9 & & 2 & 54 & 0.27 \\
\hline Coloeus monedula & & 27 & & 11 & & 4 & 42 & 0.21 \\
\hline Pica pica & & 32 & & 7 & & 2 & 41 & 0.20 \\
\hline Garrulus glandarius & & 20 & & 6 & & 3 & 29 & 0.14 \\
\hline Eliomys quercinus & & 19 & & 6 & & 1 & 26 & 0.13 \\
\hline Mustela erminea & & 18 & & 6 & & 1 & 25 & 0.12 \\
\hline Microtus agrestis & & 17 & & 7 & & & 24 & 0.12 \\
\hline Vulpes vulpes & & 12 & & 6 & & 3 & 21 & 0.10 \\
\hline Glis glis & & 9 & & 8 & & 1 & 18 & 0.09 \\
\hline Muscardinus avellanarius & & 10 & & 6 & & 1 & 17 & 0.08 \\
\hline Neomys fodiens & & 14 & & 2 & & & 16 & 0.08 \\
\hline Athene noctua & & 11 & & 4 & & 1 & 16 & 0.08 \\
\hline Eptesicus serotinus & & 14 & & 1 & & & 15 & 0.07 \\
\hline Sorex araneus & & 9 & & 4 & & 1 & 14 & 0.07 \\
\hline Vanellus vanellus & & 7 & & 6 & & 1 & 14 & 0.07 \\
\hline
\end{tabular}


Appendix 5. Continuation.

Príloha 5. Pokračovanie.

\begin{tabular}{|c|c|c|c|c|c|}
\hline $\begin{array}{l}\text { obdobie (roky pred) / period (years ago) } \\
\text { period No. / obdobie č. } \\
\text { taxa / taxón }\end{array}$ & $\begin{array}{l}A:>70 \\
1\end{array}$ & $\begin{array}{l}\text { B: } 30-70 \\
2\end{array}$ & $\begin{array}{l}C:<30 \\
3\end{array}$ & $\Sigma$ & $\%$ \\
\hline Myotis myotis & 6 & 7 & & 13 & 0.06 \\
\hline Buteo buteo & 6 & 4 & 2 & 12 & 0.06 \\
\hline Crex crex & 9 & 2 & 1 & 12 & 0.06 \\
\hline Columba oenas & 9 & 2 & 1 & 12 & 0.06 \\
\hline Fringilla coelebs & 11 & 1 & & 12 & 0.06 \\
\hline Mammalia & 7301 & 3007 & 662 & 10,970 & 54.59 \\
\hline Aves & 768 & 596 & 178 & 1542 & 7.67 \\
\hline Amphibia, Reptilia, Pisces & 6493 & 997 & 80 & 7570 & 37.67 \\
\hline Evertebrata & 7 & 4 & 1 & 12 & 0.06 \\
\hline$\Sigma$ & 14,569 & 4604 & 921 & 20,094 & 100.00 \\
\hline Diversity Index H' & 1.96 & 2.52 & 2.77 & 2.22 & \\
\hline
\end{tabular}

Others prey species (Period no.-no. of items): Ostatné druhy (Obdobie č.-počet):

Sorex minutus (1-2), Neomys anomalus (1-6; 3-1), Crocidura leucodon (1-8; 2-1), Crocidura suaveolens (1-5; 2-1), Rhinolophus hipposideros (1-1), Vespertilio murinus (1-2; 2-1; 3-1), Nyctalus noctula (1-2; 2-2), Pipistrellus pipistrellus (1-5), Barbastella barbastellus (1-5; 2-3), Plecotus auritus (1-1), Dryomys nitedula (2-1), Micromys minutus (1-6; 2-1; 3-1), Rattus rattus (1-1), Cricetus cricetus (1-5), Ondatra zibethicus (2-2; 3-1), Terricola tatricus (1-2), Canis familiaris (1-1), Martes foina (2-1), Martes sp. (2-1), Mustela putorius (2-1), Felis catus dom. (2-1), Capra ibex hircus (1-1), Podiceps cristatus (2-1), Podiceps nigricollis (2-1), Tachybaptus ruficollis (2-3; 3-1), Anser fabalis (1-1), Anas crecca (1-1; 2-1; 3-2), Anatidae sp. (1-2; 2-1), Accipiter gentilis (1-3; 21; 3-2), Accipiter nisus (1-4; 2-1), Circus sp. (1-1), Falco peregrinus (1-2; 2-2), Falco sp. (2-2), Gallus gallus dom. (1-8), Meleagris gallopavo dom. (3-1), Rallus aquaticus (1-1), Porzana porzana (1-2), Zapornia parva (3-1), Gallinula chloropus (1-5; 2-3; 3-1), Fulica atra $(1-1 ; 2-2)$, Charadrius dubius $(1-2 ; 2-3)$, Pluvialis apricaria (2-1), Actitis hypoleucos (1-8; 2-1; 3-1), Philomachus pugnax (1-1), Gallinago gallinago (1-1), Chroicocephalus ridibundus (2-1; 3-1), Sterna hirundo (2-1), Chlidonias niger (1-1; 2-1), Columba palumbus (1-11), Columba sp. (1-6; 2-35), Streptopelia turtur (1-4; 2-6; 3-1), Cuculus canorus (1-1; 2-1), Tyto alba (22), Bubo bubo (1-3; 2-3; 3-2), Asio flammeus (1-1; 3-1), Aegolius funereus (1-2; 2-1; 3-1), Strix uralensis (1-1), Caprimulgus europaeus (1-3; 2-2; 3-1), Apus apus (1-1; 3-1), Dryocopus martius (2-2), Picus viridis (3-2), Dendrocopos major (2-1), Dendrocopos leucotos (1-1), Lullula arborea (1-10), Galerida cristata (1-2; 3-1), Delichon urbicum (1-1), Anthus pratensis (3-1), Anthus spinoletta (1-2), Motacilla alba (1-3; 2-2), Lanius excubitor (2-1), Lanius minor (1-7), Sylvia sp. (1-1), Phylloscopus sibilatrix (1-1), Sylviidae sp. (1-4), Muscicapa striata (2-1), Oenanthe oenanthe (2-1), Erithacus rubecula (1-5), Turdus torquatus (3-3), Turdus iliacus (1-1), Turdus viscivorus (1-4; 2-3), Parus major (1-2), Poecile palustris (1-2), Parus sp. (2-1), Emberiza citrinella (15; 2-4), Carduelis spinus (3-1), Carduelis chloris (1-1), Coccothraustes coccothraustes (1-5; 3-4), Passer domesticus (1-6; 2-2), Passer montanus (2-1; 3-2), Nucifraga caryocatactes (1-1; 2-1), Corvus corax (1-2; 2-1; 3-2), Passeriformes sp. (1-6; 2-4), Aves sp. (2-7), Pelobates fuscus (1-2; 2-2), Bufo bufo (2-2), Bufotes viridis (2-2), Hyla arborea (1-1), Anguis fragilis (1-1), Lacerta agilis (1-4), Lacerta muralis (1-1), Lacerta sp. (1-1; 2-1), Zootoeca vivipara (1-1), Natrix natrix (1-2), Colubridae sp. (1-1), Cypriniformes sp. (1-6; 2-15; 3-1), Pisces sp. (1-6; 2-20), Hymenoptera sp. (1-1), Coleoptera sp. (1-5; 2-4; 3-1), Limacidae sp. (1-1). 
Obuch J: Spatial and temporal changes in the diet composition of the Eurasian eagle-owl (Bubo bubo) in Slovakia comparing three historical periods

Appendix 6. Comparison of Eurasian eagle-owl diets over two historical periods in the central Považie (Váh river basin) area.

Príloha 6. Porovnanie potravy výra skalného z dvoch období na strednom Považí.

\begin{tabular}{|c|c|c|c|c|}
\hline $\begin{array}{l}\text { obdobie (roky pred) / period (years ago) } \\
\text { period No. / obdobie č. } \\
\text { taxa / taxón }\end{array}$ & $\begin{array}{l}A:>70 \\
1\end{array}$ & $\begin{array}{l}\text { B: } 30-70 \\
2\end{array}$ & $\Sigma$ & $\%$ \\
\hline Rana temporaria $(\mathrm{n} / \mathrm{ks})$ & 1068 & 212 & 1280 & 15.02 \\
\hline$\%$ & 24.99 & 4.99 & & \\
\hline Pelophylax cf. esculentus & 52 & 16 & 68 & 0.80 \\
\hline Pelobates fuscus & $1+$ & $2-$ & 32 & 0.38 \\
\hline Apodemus microps & 596 & 26 & 622 & 7.30 \\
\hline Cricetus cricetus & 118 & 16 & 134 & 1.57 \\
\hline Erinaceus roumanicus & 34 & 207 & 241 & 2.83 \\
\hline Lepus europaeus & 37 & 96 & 133 & 1.56 \\
\hline Rattus norvegicus & 43 & 174 & 217 & 2.55 \\
\hline Apodemus flavicollis & 160 & 298 & 458 & 5.37 \\
\hline Myodes glareolus & 45 & 135 & 180 & 2.11 \\
\hline Microtus arvalis (n/ks) & 862 & 1513 & 2375 & 27.87 \\
\hline$\%$ & 20.17 & 35.61 & & \\
\hline Perdix perdix & 33 & 207 & 240 & 2.82 \\
\hline Phasianus colchicus & $2-$ & 34 & 38 & 0.45 \\
\hline Columba livia dom. & $2-$ & $1+$ & 36 & 0.42 \\
\hline Asio otus & 24 & 78 & 102 & 1.20 \\
\hline Turdus philomelos & $1-$ & 27 & 31 & 0.36 \\
\hline Corvus cornix + frugilegus & 65 & 121 & 186 & 2.18 \\
\hline Cypriniformes sp. & 2- & 54 & 63 & 0.74 \\
\hline Vanellus vanellus & $1-$ & 10 & 11 & 0.13 \\
\hline Apodemus sylvaticus & 457 & 314 & 771 & 9.05 \\
\hline Apodemus agrarius & 20 & $1-$ & 27 & 0.32 \\
\hline Gallus gallus dom. & 10 & $1-$ & 11 & 0.13 \\
\hline Ârvicola amphibius & $\overline{6} \bar{c}^{-}$ & 69 & 135 & 1.58 \\
\hline Mus musculus & 59 & 43 & 102 & 1.20 \\
\hline Strix aluco & 37 & 57 & 94 & 1.10 \\
\hline Coloeus monedula & 32 & 32 & 64 & 0.75 \\
\hline Talpa europaea & 33 & 20 & 53 & 0.62 \\
\hline Coturnix coturnix & 27 & 21 & 48 & 0.56 \\
\hline Terricola subterraneus & 26 & 20 & 46 & 0.54 \\
\hline Mustela nivalis & 18 & 19 & 37 & 0.43 \\
\hline Turdus merula & 13 & 23 & 36 & 0.42 \\
\hline Scolopax rusticola & 19 & 16 & 35 & 0.41 \\
\hline Sciurus vulgaris & 10 & 21 & 31 & 0.36 \\
\hline Anas platyrhynchos & 10 & 21 & 31 & 0.36 \\
\hline Falco tinnunculus & 10 & 19 & 29 & 0.34 \\
\hline Columba oenas & 14 & 12 & 26 & 0.31 \\
\hline Nyctalus noctula & 17 & 8 & 25 & 0.29 \\
\hline Pica pica & 13 & 11 & 24 & 0.28 \\
\hline Alauda arvensis & 15 & 7 & 22 & 0.26 \\
\hline Garrulus glandarius & 7 & 14 & 21 & 0.25 \\
\hline Glis glis & 4 & 12 & 16 & 0.19 \\
\hline Muscardinus avellanarius & 5 & 10 & 15 & 0.18 \\
\hline Eliomys quercinus & 10 & 3 & 13 & 0.15 \\
\hline Mustela erminea & 7 & 6 & 13 & 0.15 \\
\hline Buteo buteo & 4 & 7 & 11 & 0.13 \\
\hline Crex crex & 2 & 8 & 10 & 0.12 \\
\hline Columba palumbus & 8 & 2 & 10 & 0.12 \\
\hline Mammalia & 2666 & 3062 & 5728 & 67.21 \\
\hline Aves & 431 & 892 & 1323 & 15.52 \\
\hline Amphibia, Reptilia, Pisces & 1170 & 295 & 1465 & 17.19 \\
\hline Evertebrata & 6 & 0 & 6 & 0.07 \\
\hline$\Sigma$ & 4273 & 4249 & 8522 & 100.00 \\
\hline Diversity Index H' & 2.66 & 2.85 & 2.9 & \\
\hline
\end{tabular}


Appendix 7. Comparison of Eurasian eagle-owl diets over two historical periods in the upper Ponitrie area.

Príloha 7. Porovnanie potravy výra skalného z dvoch období na hornom Ponitrí.

\begin{tabular}{|c|c|c|c|c|c|c|c|c|}
\hline \multirow{2}{*}{$\begin{array}{l}\text { obdobie (roky pred) / period (years ago) } \\
\text { period No. / obdobie č. } \\
\text { taxa / taxón } \\
\text { Rana temporaria }(\mathrm{n} / \mathrm{ks})\end{array}$} & \multicolumn{2}{|c|}{$\begin{array}{l}A:>70 \\
1\end{array}$} & \multicolumn{2}{|c|}{$\begin{array}{l}\text { B: } 30-70 \\
2\end{array}$} & \multicolumn{2}{|c|}{$\begin{array}{l}\mathrm{C}:<30 \\
3\end{array}$} & $\Sigma$ & $\%$ \\
\hline & $1+$ & 226 & & 146 & 4- & 3 & 375 & 7.56 \\
\hline$\%$ & & 10.78 & & 7.37 & & 0.34 & & \\
\hline Apodemus microps & $1+$ & 43 & $1-$ & 21 & & 11 & 75 & 1.51 \\
\hline Apodemus sylvaticus & $1+$ & 276 & & 208 & $2-$ & 34 & 518 & 10.44 \\
\hline Mus musculus & $1+$ & 62 & $1-$ & 10 & $1-$ & 8 & 80 & 1.61 \\
\hline Myodes glareolus & $1+$ & 41 & & 24 & $1-$ & 3 & 68 & 1.37 \\
\hline Arvicola amphibius & $1-$ & 40 & $1+$ & 77 & & 22 & 139 & 2.8 \\
\hline Corvus cornix +frugilegus & & 28 & $1+$ & 43 & $1-$ & 5 & 76 & 1.53 \\
\hline Perdix perdix & $1-$ & 27 & $1+$ & 81 & & 15 & 123 & 2.48 \\
\hline Phasianus colchicus & $1-$ & 1 & $1+$ & 17 & & 5 & 23 & 0.46 \\
\hline Asio otus & $1-$ & 12 & $1+$ & 31 & & 10 & 53 & 1.07 \\
\hline Rattus norvegicus & 3- & 15 & & 96 & $2+$ & 184 & 295 & 5.95 \\
\hline Columba livia dom. & $3-$ & 1 & & 25 & $2+$ & 38 & 64 & 1.29 \\
\hline Erinaceus roumanicus & $1-$ & 25 & & 46 & $1+$ & 50 & 121 & 2.44 \\
\hline Cricetus cricetus & $1-$ & 22 & & 30 & $1+$ & 20 & 72 & 1.45 \\
\hline Turdus merula & $1-$ & 3 & & 12 & $1+$ & 19 & 34 & 0.69 \\
\hline Turdus philomelos & & 9 & & 11 & $1+$ & 15 & 35 & 0.71 \\
\hline Garrulus glandarius & & 2 & & 2 & $1+$ & 9 & 13 & 0.26 \\
\hline Lucanus cervus & $2-$ & 0 & $2-$ & 0 & $2+$ & 21 & 21 & 0.42 \\
\hline Sciurus vulgaris & $1-$ & 2 & & 12 & & 8 & 22 & 0.44 \\
\hline Columba oenas & $1-$ & 1 & & 6 & & 6 & 13 & 0.26 \\
\hline Sturnus vulgaris & $1-$ & 1 & & 7 & & 6 & 14 & 0.28 \\
\hline Apodemus flavicollis & & 202 & & 160 & $1-$ & 36 & 398 & 8.02 \\
\hline Microtus arvalis $(\mathrm{n} / \mathrm{ks})$ & & 825 & & 637 & $1-$ & 243 & 1705 & 34.36 \\
\hline$\%$ & & 39.36 & & 32.16 & & 27.46 & & \\
\hline Lepus europaeus & & $4 \overline{3}$ & & 54 & & 26 & 123 & 2.48 \\
\hline Coturnix coturnix & & 17 & & 9 & & 2 & 28 & 0.56 \\
\hline Alauda arvensis & & 10 & & 13 & & 4 & 27 & 0.54 \\
\hline Mustela nivalis & & 11 & & 12 & & 3 & 26 & 0.52 \\
\hline
\end{tabular}

Appendix 6. Continuation.

Príloha 6. Pokračovanie.

Others prey species (Period no.-no. of items): Ostatné druhy (Obdobie č.-počet):

Sorex araneus (1-2; 2-6), Sorex minutus (2-2), Neomys anomalus (1-2), Neomys fodiens (1-4), Crocidura leucodon (1-2; 2-3), Crocidura suaveolens (1-4; 2-4), Myotis mystacinus (1-1), Myotis myotis (1-5; 2-4), Myotis blythii (1-1), Vespertilio murinus (1-2; 21), Eptesicus serotinus (1-3; 2-6), Pipistrellus pipistrellus (2-5), Barbastella barbastellus (2-2), Plecotus auritus (1-1; 2-2), Spermophilus citellus (2-1), Dryomys nitedula (2-1), Sicista betulina (1-1), Micromys minutus (1-4), Ondatra zibethicus (2-2), Vulpes vulpes (1-3; 2-5), Mustela putorius (1-1), Mustela eversmanni (1-1), Felis catus dom. (1-1; 2-1), Ovis ammon aries (1-1), Tachybaptus ruficollis (1-1; 2-1), Nycticorax nycticorax (2-1), Mareca penelope (1-1), Anas crecca (2-4), Anas querquedula (2-4), Bucephala clangula (2-1), Anatidae sp. (1-4; 2-6), Accipiter gentilis (1-2; 2-1), Accipiter nisus (1-3; 2-1), Falco peregrinus (1-1), Falco sp. (2-1), Lyrurus tetrix (2-4), Rallus aquaticus (1-3), Porzana porzana (1-1; 2-3), Gallinula chloropus (1-2; 2-2), Fulica atra (2-3), Rallidae sp. (2-2), Charadrius dubius (2-1), Tringa ochropus (2-1), Actitis hypoleucos (2-2), Philomachus pugnax (1-1), Limosa limosa (1-1), Limicolae sp. (2-3), Sterna hirundo (1-1; 2-1), Columba sp. (1-1; 2-10), Streptopelia decaocto (2-4), Streptopelia turtur (1-3; 2-4), Cuculus canorus (2-7), Tyto alba (1-1; 2-1), Bubo bubo (2-4), Asio flammeus (2-1), Aegolius funereus (1-1; 2-1), Athene noctua (1-6; 2-3), Strix uralensis (2-1), Caprimulgus europaeus (1-1), Apus apus (1-1), Picus canus (12), Picus viridis (2-1), Dendrocopos major (1-1), Dendrocopos syriacus (1-1), Jynx torquilla (2-2), Lullula arborea (2-3), Galerida cristata (1-2; 2-4), Hirundo rustica (1-1), Delichon urbicum (1-1; 2-2), Motacilla alba (2-1), Motacilla cinerea (2-1), Lanius collurio (2-1), Phoenicurus ochruros (2-1), Erithacus rubecula $(1-1 ; 2-1)$, Turdus pilaris $(1-5 ; 2-3)$, Turdus viscivorus (1-3; 2-1), Cinclus cinclus (2-1), Emberiza citrinella (1-4; 2-3), Emberiza calandra (1-2), Fringilla coelebs (1-1; 2-1), Carduelis carduelis (2-1), Carduelis cannabina (1-1), Coccothraustes coccothr. (1-2; 2-2), Passer domesticus (1-5; 2-1), Passer montanus (1-1), Sturnus vulgaris (1-2; 2-3), Nucifraga caryocatactes (2-1), Corvus corax (1-1), Passeriformes sp. (1-4; 2-14), Aves sp. (2-6), Bufo bufo (1$1 ; 2-2)$, Bufotes viridis (1-1), Rana arvalis (2-1), Lacerta viridis (2-2), Lacerta agilis (1-3; 2-1), Lacerta muralis (2-2), Serpentes sp. (2-2), Salmo trutta (1-1; 2-2), Salmonidae sp. (1-2), Pisces sp. (1-2), Coleoptera sp. (1-5), Astacus sp. (1-1). 
Obuch J: Spatial and temporal changes in the diet composition of the Eurasian eagle-owl (Bubo bubo) in Slovakia comparing three historical periods

Appendix 7. Continuation.

Príloha 7. Pokračovanie.

\begin{tabular}{|c|c|c|c|c|c|}
\hline $\begin{array}{l}\text { obdobie (roky pred) / period (years ago) } \\
\text { period No. / obdobie č. } \\
\text { taxa / taxón }\end{array}$ & $\begin{array}{l}A:>70 \\
1\end{array}$ & $\begin{array}{l}\text { B: } 30-70 \\
2\end{array}$ & $\begin{array}{l}\mathrm{C}:<30 \\
3\end{array}$ & $\Sigma$ & $\%$ \\
\hline Scolopax rusticola & 10 & 7 & 25 & 0.50 & \\
\hline Pelophylax cf. esculentus & 15 & 7 & 1 & 23 & 0.46 \\
\hline Talpa europaea & 5 & 11 & 4 & 20 & 0.40 \\
\hline Spermophilus citellus & 5 & 10 & 1 & 16 & 0.32 \\
\hline Lacerta viridis & 9 & 6 & 1 & 16 & 0.32 \\
\hline Lacerta agilis & 4 & 10 & & 14 & 0.28 \\
\hline Eliomys quercinus & 9 & 4 & & 13 & 0.26 \\
\hline Strix aluco & 6 & 6 & 1 & 13 & 0.26 \\
\hline Terricola subterraneus & 5 & 6 & & 11 & 0.22 \\
\hline Pica pica & 2 & 6 & 3 & 11 & 0.22 \\
\hline Crocidura suaveolens & 4 & 5 & 1 & 10 & 0.20 \\
\hline Turdus pilaris & 1 & 6 & 3 & 10 & 0.20 \\
\hline Mammalia & 1659 & 1457 & 662 & 3778 & 76.14 \\
\hline Aves & 171 & 344 & 195 & 710 & 14.31 \\
\hline Amphibia, Reptilia, Pisces & 265 & 180 & 3- & 452 & 9.11 \\
\hline Evertebrata & 1- & 0 & 21 & 22 & 0.44 \\
\hline$\sum$ & 2096 & 1981 & 885 & 4962 & 100.00 \\
\hline Diversity Index H' & 2.4 & 2.84 & 2.82 & 2.79 & \\
\hline
\end{tabular}

Others prey species (Period no.-no. of items): Ostatné druhy (Obdobie č.-počet):

Sorex araneus (2-5), Sorex minutus (2-2; 3-1), Neomys anomalus (2-3), Neomys fodiens (2-1), Crocidura leucodon (1-4; 2-3), Rhinolophus hipposideros (1-1), Myotis emarginatus (3-1), Myotis myotis (2-1), Myotis blythii (2-1), Vespertilio murinus (1-2), Eptesicus serotinus (1-1; 2-2; 3-1), Nyctalus noctula (1-2; 2-1), Barbastella barbastellus (2-2), Glis glis (2-1), Muscardinus avellanarius (1-2), Micromys minutus (2-1; 3-3), Apodemus agrarius (1-5), Dicrostonyx gulielmi (1-1), Lasiopodomys gregalis (11), Alexandromys oeconomus (1-1), Vulpes vulpes (1-3; 2-5; 3-1), Mustela erminea (1-1; 2-5), Mustela putorius (2-1), Felis catus dom. (3-1), Tachybaptus ruficollis (3-2), Anas platyrhynchos (2-1; 3-2), Anas crecca (3-1), (1-1; 2-1), Accipiter gentilis (3-2), Accipiter nisus (2-1; 3-3), Buteo buteo (2-2; 3-2), Falco tinnunculus (2-5; 3-4), Rallus aquaticus (1-1; 3-2), Zapornia parva (1-1), Porzana sp. (1-1), Crex crex (1-4; 2-1; 3-2), Gallinula chloropus (2-2), Fulica atra (3-1), Charadrius dubius (2-3; 3-1), Vanellus vanellus (1-2; 2-3; 3-1), Actitis hypoleucos (1-2; 2-2), Columba palumbus (1-3; 2-3; 3-2), Streptopelia decaocto (3-1), Streptopelia turtur (1-1; 2-3; 3-2), Cuculus canorus $(1-1 ; 2-2 ; 3-2)$, Bubo bubo (3-1), Asio flammeus (3-1), Otus scops (1-2), Aegolius funereus (1-1; 2-2), Athene noctua (1-4; 2-2; 3-1), Caprimulgus europaeus (2-1), Coracias garrulus (2-1), Lullula arborea (1-2), Galerida cristata (2-2), Lanius excubitor (1-1; 2-1), Lanius minor (1-1; 2-1), Lanius collurio (1-1; 2-1; 3-1), Sylvia atricapilla (2-2), Oenanthe oenanthe (1-2), Erithacus rubecula $(2-1 ; 3-1)$, Turdus viscivorus (1-1; 2-3), Parus major (3-1), Cyanistes caeruleus (2-1), Emberiza citrinella (1-1; 3-1), Carduelis chloris (2-1), Coccothraustes coccothr. (3-2), Passer domesticus (2-2; 32), Oriolus oriolus (1-1; 2-1), Coloeus monedula (1-2; $2-1 ; 3-1)$, Passeriformes sp. (1-3; 2-9; 3-3), Aves sp. (3-1), Aves sp. juv. (11; 2-1), Pelobates fuscus (1-4), Rana dalmatina (1-1; 2-2), Pelophylax ridibundus (1-2; 2-2; 3-1), Lacerta muralis (2-1), Colubridae sp. (2-2), Salmo trutta (1-1), Cypriniformes sp. (3-1), Pisces sp. (1-3; 2-4), Coleoptera sp. (1-1). 
Appendix 8. Comparison of Eurasian eagle-owl diets over three historical periods in the Pohronie (Hron river basin) area.

Príloha 8. Porovnanie potravy výra skalného z troch období na Pohroní.

\begin{tabular}{|c|c|c|c|c|c|c|c|}
\hline $\begin{array}{l}\text { obdobie (roky pred) / period (years ago) } \\
\text { period No. / obdobie č. } \\
\text { taxa / taxón }\end{array}$ & $\begin{array}{l}\text { A: } \\
1\end{array}$ & & $\begin{array}{l}\text { B: } 30-70 \\
2\end{array}$ & $\begin{array}{l}\text { C: } \\
3\end{array}$ & & $\Sigma$ & $\%$ \\
\hline Rana temporaria (n/ks) & $2+$ & 56 & 147 & 2- & 2.7 & 210 & 15.70 \\
\hline$\%$ & & 70 & 14.38 & & 2.97 & & \\
\hline Erinaceus roumanicus & & 1 & 30 & $1+$ & 19 & 50 & 3.74 \\
\hline Rattus norvegicus & $1-$ & 2 & 107 & $1+$ & 63 & 172 & 12.86 \\
\hline Arvicola amphibius & & 4 & 117 & $1-$ & 10 & 131 & 9.79 \\
\hline Microtus arvalis (n/ks) & $1-$ & 12 & 330 & $1-$ & 48 & 390 & 29.15 \\
\hline$\%$ & & 15 & 32.29 & & 20.34 & & \\
\hline Apodemus flavicollis & & & 29 & & 4 & 33 & $2 . \overline{4}$ \\
\hline Corvus cornix + frugilegus & & & 24 & & 7 & 31 & 2.32 \\
\hline Cypriniformes sp. & & & 24 & & 3 & 27 & 2.02 \\
\hline Asio otus & & & 19 & & 6 & 25 & 1.87 \\
\hline Perdix perdix & & & 20 & & 4 & 24 & 1.79 \\
\hline Apodemus sylvaticus & & & 14 & & 1 & 15 & 1.12 \\
\hline Lepus europaeus & & & 8 & & 5 & 13 & 0.97 \\
\hline Alauda arvensis & & & 13 & & & 13 & 0.97 \\
\hline Columba livia dom. & & & 6 & & 5 & 11 & 0.82 \\
\hline Strix aluco & & & 9 & & 2 & 11 & 0.82 \\
\hline Scolopax rusticola & & & 10 & & & 10 & 0.75 \\
\hline Anas platyrhynchos & & 1 & 6 & & 2 & 9 & 0.67 \\
\hline Myodes glareolus & & & 5 & & 2 & 7 & 0.52 \\
\hline Mustela nivalis & & & 7 & & & 7 & 0.52 \\
\hline Turdus merula & & & 3 & & 4 & 7 & 0.52 \\
\hline Talpa europaea & & & 6 & & & 6 & 0.45 \\
\hline Coloeus monedula & & & 6 & & & 6 & 0.45 \\
\hline Mammalia & 1- & 20 & 675 & & 158 & 853 & 63.75 \\
\hline Aves & 2- & 2 & 175 & $1+$ & 66 & 243 & 18.16 \\
\hline Amphibia, Reptilia, Pisces & $2+$ & 58 & 172 & 2- & 10 & 240 & 17.94 \\
\hline Evertebrata & & 0 & 0 & & 2 & 2 & 0.15 \\
\hline$\Sigma$ & & 80 & 1022 & & 236 & 1338 & 100.00 \\
\hline Diversity Index H' & & 1.09 & 2.59 & & 2.79 & 2.69 & \\
\hline
\end{tabular}

Others prey species (Period no.-no. of items): Ostatné druhy (Obdobie č.-počet):

Crocidura leucodon (2-1), Myotis mystacinus (2-1), Myotis myotis (2-4; 3-1), Vespertilio murinus (2-1), Eptesicus serotinus (2-1), Nyctalus noctula (2-2), Sciurus vulgaris (3-1), Glis glis (2-3; 3-1), Eliomys quercinus (2-1; 3-2), Muscardinus avellanarius (2-1), Mus musculus (2-1), Terricola subterraneus (1-1; 2-1), Vulpes vulpes (2-2), Mustela erminea (2-3; 3-1), Tachybaptus ruficollis (22; 3-1), Anser anser dom. (1-1), Anas crecca (2-1; 3-1), Anas querquedula (3-1), Anas acuta (2-1; 3-1), Anatidae sp. (2-6), Accipiter gentilis (2-1), Accipiter nisus (2-1), Buteo buteo (2-1; 3-2), Pernis apivorus (2-1), Falco tinnunculus (2-1; 3-4), Coturnix coturnix (2-4; 3-1), Phasianus colchicus (3-3), Gallus gallus dom. (2-1), Rallus aquaticus (2-1), Crex crex (2-4), Gallinula chloropus (2-2; 3-1), Fulica atra (2-2; 3-1), Vanellus vanellus (2-5; 3-3), Actitis hypoleucos (2-2), Gallinago sp. (2-1), Columba oenas (3-1), Columba palumbus (2-1; 3-1), Streptopelia decaocto (2-2; 3-1), Streptopelia turtur (2-1), Athene noctua (3-1), Apus apus (2-1), Anthus trivialis (2-1), Sylviidae sp. (2-1), Turdus pilaris (2-2; 3-2), Turdus philomelos (2-1; 3-4), Turdus viscivorus (21), Emberiza schoeniclus (2-1), Fringilla coelebs (3-1), Coccothraustes coccothr. (3-3), Sturnus vulgaris (2-3), Garrulus glandarius $(2-1 ; 3-1)$, Pica pica (2-2; 3-1), Passeriformes sp. (2-1), Aves sp. (2-3), Aves sp. juv. (3-1), Pelophylax cf. esculentus (2-1), Salmo trutta (1-2), Lucanus cervus (3-2). 
Obuch J: Spatial and temporal changes in the diet composition of the Eurasian eagle-owl (Bubo bubo) in Slovakia comparing three historical periods

Appendix 9. Comparison of Eurasian eagle-owl diets over three historical periods on the Muránska planina Plateau.

Príloha 9. Porovnanie potravy výra skalného z troch období na Muránskej planine.

\begin{tabular}{|c|c|c|c|c|c|c|c|c|}
\hline \multirow{2}{*}{$\begin{array}{l}\text { obdobie (roky pred) / period (years ago) } \\
\text { period No. / obdobie č. } \\
\text { taxa / taxón } \\
\text { Rana temporaria }(\mathrm{n} / \mathrm{ks})\end{array}$} & \multicolumn{2}{|c|}{$\begin{array}{l}A:>70 \\
1\end{array}$} & \multicolumn{2}{|c|}{$\begin{array}{l}\text { B: } 30-70 \\
2\end{array}$} & \multicolumn{2}{|c|}{$\begin{array}{l}\mathrm{C}:<30 \\
3\end{array}$} & $\Sigma$ & $\%$ \\
\hline & $1+$ & 674 & & 928 & $1-$ & 194 & 1796 & 22.27 \\
\hline$\%$ & & 28.82 & & 22.8 & & 11.72 & & \\
\hline Microtus arvalis (n/ks) & $1+$ & 980 & $1-$ & 1065 & & 592 & 2637 & 32.70 \\
\hline$\%$ & & 41.9 & & 26.16 & & 35.77 & & \\
\hline Apodemus sylvaticus & $1+$ & 40 & $1-$ & 35 & & 23 & 98 & 1.22 \\
\hline Apodemus flavicollis & & 41 & $1+$ & 116 & $1-$ & 20 & 177 & 2.19 \\
\hline Myodes glareolus & $1-$ & 8 & $1+$ & 68 & $1-$ & 5 & 81 & 1.00 \\
\hline Alauda arvensis & $1-$ & 6 & $1+$ & 33 & & 6 & 45 & 0.56 \\
\hline Corvus cornix + frugilegus & $1-$ & 7 & $1+$ & 40 & & 6 & 53 & 0.66 \\
\hline Columba oenas & $1-$ & 0 & $1+$ & 17 & & & 17 & 0.21 \\
\hline Rattus norvegicus & 3- & 6 & & 176 & $1+$ & 126 & 308 & 3.82 \\
\hline Arvicola amphibius & $1-$ & 388 & & 1055 & $1+$ & 501 & 1944 & 24.10 \\
\hline Erinaceus roumanicus & $1-$ & 6 & & 33 & & 15 & 54 & 0.67 \\
\hline Perdix perdix & $1-$ & 4 & & 22 & & 8 & 34 & 0.42 \\
\hline Asio otus & $1-$ & 5 & & 19 & & 13 & 37 & 0.46 \\
\hline Garrulus glandarius & $1-$ & 0 & & 13 & & 5 & 18 & 0.22 \\
\hline Spermophilus citellus & & 4 & & 16 & $1-$ & 0 & 20 & 0.25 \\
\hline Talpa europaea & & 20 & & 22 & & 10 & 52 & 0.64 \\
\hline Microtus agrestis & & 12 & & 16 & & 5 & 33 & 0.41 \\
\hline Lepus europaeus & & 5 & & 20 & & 7 & 32 & 0.40 \\
\hline Terricola subterraneus & & 7 & & 20 & & 2 & 29 & 0.36 \\
\hline Coturnix coturnix & & 7 & & 13 & & 8 & 28 & 0.35 \\
\hline Scolopax rusticola & & 4 & & 16 & & 4 & 24 & 0.30 \\
\hline Strix aluco & & 6 & & 17 & & 1 & 24 & 0.30 \\
\hline Turdus philomelos & & 3 & & 18 & & 3 & 24 & 0.30 \\
\hline Turdus merula & & 3 & & 11 & & 8 & 22 & 0.27 \\
\hline Mus musculus & & 5 & & 9 & & 7 & 21 & 0.26 \\
\hline Mustela nivalis & & 7 & & 10 & & 3 & 20 & 0.25 \\
\hline Dryomys nitedula & & 10 & & 6 & & 3 & 19 & 0.24 \\
\hline Muscardinus avellanarius & & 6 & & 8 & & 4 & 18 & 0.22 \\
\hline Streptopelia turtur & & 5 & & 13 & & & 18 & 0.22 \\
\hline Sciurus vulgaris & & 2 & & 9 & & 6 & 17 & 0.21 \\
\hline Pica pica & & 1 & & 12 & & 3 & 16 & 0.20 \\
\hline Salmo trutta & & 3 & & 5 & & 5 & 13 & 0.16 \\
\hline Mustela erminea & & 2 & & 5 & & 5 & 12 & 0.15 \\
\hline Columba livia dom. & & 1 & & 8 & & 3 & 12 & 0.15 \\
\hline Eptesicus serotinus & & 4 & & 7 & & & 11 & 0.14 \\
\hline Falco tinnunculus & & 2 & & 7 & & 2 & 11 & 0.14 \\
\hline Sorex araneus & & 2 & & 6 & & 2 & 10 & 0.12 \\
\hline Mammalia & & 1572 & & 2730 & & 1348 & 5650 & 70.06 \\
\hline Aves & $1-$ & 85 & $1+$ & 387 & & 102 & 574 & 7.12 \\
\hline Amphibia, Reptilia, Pisces & $1+$ & 681 & & 950 & $1-$ & 203 & 1834 & 22.74 \\
\hline Evertebrata & & 1 & & 4 & & 2 & 7 & 0.09 \\
\hline$\sum$ & & 2339 & & 4071 & & 1655 & 8065 & 100.00 \\
\hline Diversity Index H' & & 1.73 & & 2.31 & & 1.99 & 2.14 & \\
\hline
\end{tabular}

Others prey species (Period no.-no. of items): Ostatné druhy (Obdobie č.-počet):

Neomys anomalus (1-1), Neomys fodiens (2-4; 3-3), Crocidura leucodon (2-1), Myotis mystacinus (1-2), Myotis brandtii (1-1), Myotis nattereri (1-1), Myotis bechsteinii (1-2; 2-1), Myotis myotis (2-2), Vespertilio murinus (2-1), Nyctalus noctula (2-1), Barbastella barbastellus (1-2; 2-2), Plecotus auritus (2-1), Glis glis (1-2; 2-2; 3-4), Eliomys quercinus (1-2), Sicista betulina (1-3; 33), Apodemus microps (2-2), Apodemus agrarius (2-3; 3-1), Terricola tatricus (2-1; 3-1), Vulpes vulpes (2-4), Martes sp. (2-1), Felis catus dom. (1-1; 2-1), Cervus elaphus (2-1), Podiceps grisegena (2-1), Anas platyrhynchos (3-1), Anas crecca (1-1; 2-1), Anas querquedula (2-3), Aythya fuligula (2-1), Anatidae sp. (1-1), Accipiter gentilis (2-1), Accipiter nisus (2-2; 3-1), Buteo buteo (34), Circus sp. (2-2), Accipitridae sp. (2-2), Tetrastes bonasia (2-5; 3-2), Phasianus colchicus (2-1), Galliformes sp. (1-1), Rallus aquaticus (1-1), Porzana porzana (1-3; 2-6), Crex crex (1-1; 2-6; 3-1), Gallinula chloropus (1-1; 2-4), Fulica atra (2-1), Vanellus 
Appendix 10. Comparison of Eurasian eagle-owl diets over three historical periods in the Spiš region.

Príloha 10. Porovnanie potravy výra skalného z troch období na Spiši.

\begin{tabular}{|c|c|c|c|c|c|c|c|c|}
\hline $\begin{array}{l}\text { obdobie (roky pred) / period (years ago) } \\
\text { period No. / obdobie č. } \\
\text { taxa / taxón }\end{array}$ & & & $\begin{array}{l}\text { B: } \\
2\end{array}$ & & $\begin{array}{l}\text { C: } \\
3\end{array}$ & & $\sum$ & $\%$ \\
\hline Rana temporaria (n/ks) & $1+$ & 296 & & 716 & 4- & 10 & 1022 & 25.8 \\
\hline$\%$ & & 49.5 & & 26.76 & & 0.15 & & \\
\hline Salmo trutta & $1+$ & 11 & & 10 & & & 21 & 0.53 \\
\hline Arvicola amphibius & $1+$ & 140 & & 484 & $1-$ & 87 & 711 & 17.95 \\
\hline Mus cf. musculus & $1-$ & 2 & $1+$ & 61 & 2- & 1 & 64 & 1.62 \\
\hline Rattus norvegicus & $1-$ & 5 & 2- & 26 & $2+$ & 87 & 118 & 2.98 \\
\hline Cricetus cricetus & $2-$ & 0 & $1-$ & 23 & $2+$ & 34 & 57 & 1.44 \\
\hline Asio otus & & 1 & 1- & 6 & $2+$ & 24 & 31 & 0.78 \\
\hline Perdix perdix & & & $1-$ & 6 & $1+$ & 12 & 18 & 0.45 \\
\hline Lepus europaeus & & 3 & $1-$ & 16 & $1+$ & 25 & 44 & 1.11 \\
\hline Erinaceus roumanicus & & 2 & $1-$ & 5 & $1+$ & 8 & 15 & 0.38 \\
\hline Spermophilus citellus & & 3 & $1-$ & 1 & $1+$ & 9 & 13 & 0.33 \\
\hline Mustela nivalis & & 1 & $1-$ & 7 & $1+$ & 11 & 19 & 0.48 \\
\hline Pica pica & & & $1-$ & 0 & $1+$ & 11 & 11 & 0.28 \\
\hline Corvus cornix + frugilegus & & 2 & & 19 & $1+$ & 14 & 35 & 0.88 \\
\hline Coloeus monedula & & & 1- & 2 & $1+$ & 13 & 15 & 0.38 \\
\hline Apodemus sylvaticus & $1-$ & 3 & & 38 & & 11 & 52 & 1.31 \\
\hline Apodemus microps & $2-$ & 0 & & 45 & & 8 & 53 & 1.34 \\
\hline Microtus arvalis (n/ks) & $2-$ & 61 & & 1020 & & 264 & 1345 & 33.96 \\
\hline$\%$ & & 10.2 & & 38.12 & & 38.42 & & \\
\hline Microtus agrestis & & 4 & & 31 & $1-$ & 1 & 36 & 0.91 \\
\hline Apodemus flavicollis & & $\overline{7}$ & & 23 & & 5 & 35 & 0.88 \\
\hline Scolopax rusticola & & 4 & & 10 & & & 14 & 0.35 \\
\hline Turdus philomelos & & 3 & & 7 & & 3 & 13 & 0.33 \\
\hline Sciurus vulgaris & & 4 & & 7 & & 1 & 12 & 0.30 \\
\hline Columba livia dom. & & 2 & & 6 & & 3 & 11 & 0.28 \\
\hline Alauda arvensis & & 1 & & 7 & & 3 & 11 & 0.28 \\
\hline Mustela erminea & & 2 & & 5 & & 2 & 9 & 0.23 \\
\hline Terricola subterraneus & & 3 & & 5 & & & 8 & 0.20 \\
\hline Talpa europaea & & 1 & & 4 & & 2 & 7 & 0.18 \\
\hline Apodemus agrarius & & & & 7 & & & 7 & 0.18 \\
\hline
\end{tabular}

4 Appendix 9. Continuation.

4 Príloha 9. Pokračovanie.

vanellus (2-3; 3-1), Actitis hypoleucos (2-1), Tringa sp. (2-2), Philomachus pugnax (2-1), Chroicocephalus ridibundus (2-1), Columba palumbus (2-3; 3-1), Streptopelia decaocto (2-2), Cuculus canorus $(1-1 ; 2-5)$, Bubo bubo (1-1; 2-4; 3-1), Aegolius funereus (1-1; 2-2; 3-1), Athene noctua (3-1), Caprimulgus europaeus (1-1; 2-3), Coracias garrulus (2-2), Upupa epops (2-1), Dryocopus martius (2-1), Jynx torquilla (2-1), Lullula arborea (2-4), Galerida cristata (1-1; 2-1), Delichon urbicum (2-1; 3-1), Anthus trivialis (2-2), Motacilla alba (2-2), Motacilla cinerea (2-1), Lanius minor (1-1), Lanius collurio (1-2; 2-1), Acrocephalus palustris (3-1), Sylvia atricapilla (2-1), Phoenicurus ochruros (2-1), Erithacus rubecula (2-2; 3-1), Turdus pilaris (2-5; 3-4), Turdus viscivorus (1-3; 2-6), Parus major (2-2), Periparus ater (3-1), Lophophanes cristatus (3-1), Sitta europaea (3-1), Troglodytes troglodytes (1-1; 2-1), Emberiza citrinella (1-1; 2-3; 3-1), Emberiza calandra (2-1), Emberiza schoeniclus (1-1; 2-1), Fringilla coelebs (2-3; 3-3), Coccothraustes coccothraustes (1-1; 2-4; 3-2), Fringillidae sp. (1-1), Passer domesticus (2-1), Sturnus vulgaris (2-5; 3-1), Nucifraga caryocatactes (2-1), Coloeus monedula (2-4), Passeriformes sp. (1-6; 2-3; 3-1), Aves sp. juv. (2-4), Bufo bufo (2-2), Pelophylax cf. esculentus (2-2), Lacerta agilis (2-6; 3-3), Lacerta sp. (1-2), Zootoeca vivipara (2-2; 3-1), Natrix natrix (11), Serpentes sp. (2-1), Cypriniformes sp. (2-3), Pisces sp. (1-1; 2-1), Coleoptera sp. (1-1; 2-1; 3-2), Limacidae sp. (2-3). 
Obuch J: Spatial and temporal changes in the diet composition of the Eurasian eagle-owl (Bubo bubo) in Slovakia comparing three historical periods

Appendix 10. Continuation.

Príloha 10. Pokračovanie.

\begin{tabular}{|c|c|c|c|c|c|}
\hline $\begin{array}{l}\text { obdobie (roky pred) / period (years ago) } \\
\text { period No. / obdobie č. } \\
\text { taxa / taxón }\end{array}$ & $\begin{array}{l}A:>70 \\
1\end{array}$ & $\begin{array}{l}\text { B: } 30-70 \\
2\end{array}$ & $\begin{array}{l}\mathrm{C}:<30 \\
3\end{array}$ & $\Sigma$ & $\%$ \\
\hline Myodes glareolus & 3 & 4 & & 7 & 0.18 \\
\hline Falco tinnunculus & 3 & 2 & 2 & 7 & 0.18 \\
\hline Crex crex & 2 & 3 & 2 & 7 & 0.18 \\
\hline Mammalia & 247 & 1838 & 567 & 2652 & 66.95 \\
\hline Aves & 43 & 108 & 107 & 258 & 6.51 \\
\hline Amphibia, Reptilia, Pisces & 308 & 729 & 13 & 1050 & 26.51 \\
\hline Evertebrata & 0 & 1 & 0 & 1 & 0.03 \\
\hline $\bar{\Sigma}$ & 598 & 2676 & 687 & 3961 & 100.00 \\
\hline Diversity Index H' & 1.82 & 1.91 & 2.43 & 2.16 & \\
\hline
\end{tabular}

Others prey species (Period no.-no. of items): Ostatné druhy (Obdobie č.-počet):

Sorex araneus (1-1; 2-1), Neomys anomalus (2-1), Crocidura suaveolens (2-1), Myotis mystacinus (2-2), Myotis bechsteinii (2-1), Myotis myotis (2-2; 3-3), Eptesicus serotinus (2-3; 3-1), Glis glis (3-3), Eliomys quercinus (2-3), Dryomys nitedula (1-1), Muscardinus avellanarius (1-1; 2-4), Sicista betulina (2-3), Ondatra zibethicus (3-1), Terricola tatricus (2-1), Chionomys nivalis (22), Vulpes vulpes (2-2; 3-3), Anas platyrhynchos (1-1; 3-1), Anas crecca (1-1), Anas querquedula (3-1), Accipiter gentilis (2-2), Buteo buteo (3-1), Tetrastes bonasia (1-3; 2-2), Lyrurus tetrix (2-3), Tetrao urogallus (1-1), Coturnix coturnix (1-1; 2-3; 3-1), Gallus gallus dom. (2-1), Porzana porzana (2-1), Vanellus vanellus (3-2), Tringa sp. (1-2), Gallinago gallinago (3-1), Columba oenas (1-1; 2-1), Streptopelia turtur (1-1; 2-1; 3-1), Cuculus canorus (2-1), Bubo bubo (3-1), Aegolius funereus (1-3; 2-2), Athene noctua (3-1), Strix aluco (2-1), Strix uralensis (2-1), Dryocopus martius (2-1), Picus viridis (2-1), Dendrocopos syriacus (3-1), Lullula arborea $(1-1 ; 2-1)$, Anthus trivialis (1-1), Lanius collurio (2-2), Turdus merula (3-2), Turdus torquatus (1-2; 2-4), Turdus pilaris (3-2), Turdus iliacus (1-1), Turdus viscivorus (2-3), Lophophanes cristatus (3-1), Emberiza citrinella (1-1; 3-1), Carduelis chloris (3-1), Coccothraustes coccothr. (2-1), Loxia curvirostra (2-1), Sturnus vulgaris (1-1), Garrulus glandarius (3-1), Nucifraga caryocatactes (2-1; 3-1), Corvus corax (2-1), Passeriformes sp. (1-4; 2-3), Aves sp. (2-1), Aves sp. juv. (2-1), Bufo bufo (2-1), Bufo sp. (3-1), Lacerta agilis (2-2), Lacerta sp. (1-1), Cypriniformes sp. (3-1), Pisces sp. (3-1), Coleoptera sp. (2-1). 
Appendix 11. Comparison of Eurasian eagle-owl diets over two historical periods in the Rimavská kotlina area.

Príloha 11. Porovnanie potravy výra skalného z dvoch období v Rimavskej kotline.

\begin{tabular}{|c|c|c|c|c|}
\hline $\begin{array}{l}\text { obdobie (roky pred) / period (years ago) } \\
\text { period No. / obdobie č. } \\
\text { taxa / taxón }\end{array}$ & $\begin{array}{l}\text { B: } 30-70 \\
2\end{array}$ & $\begin{array}{l}C:<30 \\
3\end{array}$ & $\sum$ & $\%$ \\
\hline Apodemus flavicollis & $1+$ & 25 & 41 & 3.77 \\
\hline Apodemus sylvaticus & $1+$ & 38 & 54 & 4.96 \\
\hline Perdix perdix & $1+$ & 6 & 13 & 1.19 \\
\hline Rattus norvegicus & 12 & 213 & 225 & 20.68 \\
\hline Apodemus agrarius & $1-$ & 34 & 34 & 3.13 \\
\hline Microtus arvalis & $4 \overline{2}$ & $23 \overline{3}$ & 275 & 25.28 \\
\hline Arvicola amphibius & 8 & 32 & 40 & 3.68 \\
\hline Erinaceus roumanicus & 8 & 28 & 36 & 3.31 \\
\hline Asio otus & 5 & 22 & 27 & 2.48 \\
\hline Micromys minutus & 1 & 23 & 24 & 2.21 \\
\hline Turdus merula & 7 & 16 & 23 & 2.11 \\
\hline Lepus europaeus & 5 & 17 & 22 & 2.02 \\
\hline Columba livia dom. & 1 & 20 & 21 & 1.93 \\
\hline Corvus cornix + frugilegus & 3 & 17 & 20 & 1.84 \\
\hline Apodemus microps & 4 & 13 & 17 & 1.56 \\
\hline Phasianus colchicus & 4 & 9 & 13 & 1.19 \\
\hline Columba oenas & 1 & 12 & 13 & 1.19 \\
\hline Garrulus glandarius & & 13 & 13 & 1.19 \\
\hline Glis glis & 1 & 11 & 12 & 1.10 \\
\hline Turdus philomelos & 1 & 11 & 12 & 1.10 \\
\hline Rana temporaria & & 11 & 11 & 1.01 \\
\hline Gallinula chloropus & 2 & 8 & 10 & 0.92 \\
\hline Lucanus cervus & & 9 & 9 & 0.83 \\
\hline Vanellus vanellus & 3 & 5 & 8 & 0.74 \\
\hline Talpa europaea & 1 & 5 & 6 & 0.55 \\
\hline Mus cf. musculus & 1 & 5 & 6 & 0.55 \\
\hline Anas platyrhynchos & 2 & 4 & 6 & 0.55 \\
\hline Alauda arvensis & 1 & 5 & 6 & 0.55 \\
\hline Mammalia & 116 & 689 & 805 & 73.99 \\
\hline Aves & $1+$ & 189 & 239 & 21.97 \\
\hline Amphibia, Reptilia, Pisces & 1 & 25 & 26 & 2.39 \\
\hline Evertebrata & 2 & 16 & 18 & 1.65 \\
\hline$\sum$ & 169 & 919 & 1088 & 100.00 \\
\hline Diversity Index H' & 2.89 & 2.87 & 2.94 & \\
\hline
\end{tabular}

Others prey species (Period no.-no. of items): Ostatné druhy (Obdobie č.-počet):

Sorex araneus (2-1), Neomys fodiens (2-1), Crocidura suaveolens (2-2), Myotis myotis (2-1), Nyctalus noctula (2-1), Myodes glareolus (1-1; 2-2), Ondatra zibethicus (2-2), Microtus agrestis (2-1), Mustela nivalis (2-1), Tachybaptus ruficollis (2-3), Anas querquedula (1-2), Accipiter gentilis (2-2), Buteo buteo (2-3), Accipitridae sp. (2-1), Falco tinnunculus (1-1; 2-2), Coturnix coturnix $(1-1 ; 2-1)$, Rallus aquaticus (2-1), Crex crex (2-1), Fulica atra (2-2), Rallidae sp. (1-1), Scolopax rusticola (1-1), Streptopelia decaocto (2-2), Tyto alba (2-2), Bubo bubo (1-1; 2-2), Athene noctua (2-2), Strix aluco (1-1; 2-2), Galerida cristata (2-1), Erithacus rubecula (2-1), Turdus pilaris (2-3), Turdus viscivorus (2-1), Carduelis chloris (2-1), Sturnus vulgaris (1-1; 2-4), Pica pica (1-3; 22), Corvus corax (2-1), Passeriformes sp. (1-1; 2-1), Pelobates fuscus (2-1), Pelophylax cf. esculentus (2-4), Lacerta viridis (1-1; 22), Lacerta muralis (2-1), Colubridae sp. (2-1), Cypriniformes sp. (2-5), Coleoptera sp. (1-2; 2-6), Limacidae sp. (2-1). 
Obuch J: Spatial and temporal changes in the diet composition of the Eurasian eagle-owl (Bubo bubo) in Slovakia comparing three historical periods

Appendix 12. Comparison of Eurasian eagle-owl diets over three historical periods in the Slovenský kras Karst area.

Príloha 12. Porovnanie potravy výra skalného z troch období v Slovenskom krase.

\begin{tabular}{|c|c|c|c|c|c|c|c|c|}
\hline $\begin{array}{l}\text { obdobie (roky pred) / period (years ago) } \\
\text { period No. / obdobie č. } \\
\text { taxa / taxón }\end{array}$ & $\begin{array}{l}\text { A: } \\
1\end{array}$ & & $\begin{array}{l}\text { B: } \\
2\end{array}$ & & $\begin{array}{l}\text { C: } \\
3\end{array}$ & & $\Sigma$ & $\%$ \\
\hline Microtus arvalis (n/ks) & $1+$ & 53 & $1+$ & 479 & $1-$ & 120 & 652 & 25.15 \\
\hline$\%$ & & 34.87 & & 31.08 & & 13.35 & & \\
\hline Apodemus sylvaticus & & 1 & $1+$ & 58 & $1-$ & 8 & 67 & 2.58 \\
\hline Apodemus microps & & 1 & $1+$ & 24 & $1-$ & 3 & 28 & 1.08 \\
\hline Arvicola amphibius & $1-$ & 10 & $1-$ & 124 & $1+$ & 170 & 304 & 11.73 \\
\hline Columba livia dom. & & 1 & $1-$ & 21 & $1+$ & 33 & 55 & 2.12 \\
\hline Corvus cornix + frugilegus & & 2 & $1-$ & 11 & $1+$ & 17 & 30 & 1.16 \\
\hline Tachybaptus ruficollis & & & $2-$ & 0 & $1+$ & 15 & 15 & 0.58 \\
\hline Anas crecca & & & $1-$ & 0 & $1+$ & 9 & 9 & 0.35 \\
\hline Gallinula chloropus & & 1 & $1-$ & 6 & $1+$ & 20 & 27 & 1.04 \\
\hline Fulica atra & & & $1-$ & 0 & $1+$ & 7 & 7 & 0.27 \\
\hline Pelobates fuscus & & 5 & $2-$ & 19 & $1+$ & 86 & 110 & 4.24 \\
\hline Rattus norvegicus & $2-$ & 2 & & 224 & & 119 & 345 & 13.31 \\
\hline Cricetus cricetus & & 10 & & 89 & $1-$ & 26 & 125 & 4.82 \\
\hline Apodemus flavicollis & & 10 & & 85 & $1-$ & 20 & 115 & 4.44 \\
\hline Apodemus agrarius & & 2 & & 13 & $1-$ & 0 & 15 & 0.58 \\
\hline Perdix perdix & & 4 & & 41 & & 25 & 70 & 2.70 \\
\hline Erinaceus roumanicus & & & & 27 & & 22 & 49 & 1.89 \\
\hline Lepus europaeus & & 2 & & 24 & & 22 & 48 & 1.85 \\
\hline Spermophilus citellus & & 2 & & 24 & & 18 & 44 & 1.70 \\
\hline Glis glis & & 2 & & 15 & & 8 & 25 & 0.96 \\
\hline Asio otus & & 2 & & 14 & & 7 & 23 & 0.89 \\
\hline Turdus merula & & & & 18 & & 4 & 22 & 0.85 \\
\hline Coturnix coturnix & & 4 & & 10 & & 4 & 18 & 0.69 \\
\hline Vanellus vanellus & & 2 & & 8 & & 8 & 18 & 0.69 \\
\hline Anas platyrhynchos & & & & 4 & & 9 & 13 & 0.50 \\
\hline Myodes glareolus & & 2 & & 10 & & 1 & 13 & 0.50 \\
\hline Mustela nivalis & & & & 9 & & 3 & 12 & 0.46 \\
\hline Garrulus glandarius & & 1 & & 3 & & 8 & 12 & 0.46 \\
\hline Turdus philomelos & & 3 & & 6 & & 3 & 12 & 0.46 \\
\hline Talpa europaea & & & & 5 & & 6 & 11 & 0.42 \\
\hline Columba oenas & & 1 & & 8 & & 2 & 11 & 0.42 \\
\hline Coloeus monedula & & 1 & & 8 & & 2 & 11 & 0.42 \\
\hline Falco tinnunculus & & 1 & & 6 & & 4 & 11 & 0.42 \\
\hline Mus cf. musculus & & 1 & & 6 & & 3 & 10 & 0.39 \\
\hline Vulpes vulpes & & 1 & & 7 & & 2 & 10 & 0.39 \\
\hline Alauda arvensis & & & & 4 & & 6 & 10 & 0.39 \\
\hline Pica pica & & 3 & & 5 & & 2 & 10 & 0.39 \\
\hline Rana temporaria & & & & 8 & & 1 & 9 & 0.35 \\
\hline Dryomys nitedula & & 2 & & 6 & & & 8 & 0.31 \\
\hline Streptopelia decaocto & & & & 6 & & 2 & 8 & 0.31 \\
\hline Turdus pilaris & & 3 & & 2 & & 3 & 8 & 0.31 \\
\hline Scolopax rusticola & & & & 6 & & 1 & 7 & 0.27 \\
\hline Turdus viscivorus & & 1 & & 5 & & 1 & 7 & 0.27 \\
\hline Pelophylax cf.esculentus & & 2 & & 4 & & 1 & 7 & 0.27 \\
\hline Cuculus canorus & & 1 & & 4 & & 1 & 6 & 0.23 \\
\hline Terricola subterraneus & & 1 & & 5 & & & 6 & 0.23 \\
\hline Phasianus colchicus & & & & 6 & & & 6 & 0.23 \\
\hline
\end{tabular}


Appendix 12. Continuation.

Príloha 12. Pokračovanie.

\begin{tabular}{|c|c|c|c|c|c|}
\hline $\begin{array}{l}\text { obdobie (roky pred) / period (years ago) } \\
\text { period No. / obdobie č. } \\
\text { taxa / taxón }\end{array}$ & $\begin{array}{l}A:>70 \\
1\end{array}$ & $\begin{array}{l}\text { B: } 30-70 \\
2\end{array}$ & $\begin{array}{l}\mathrm{C}:<30 \\
3\end{array}$ & $\Sigma$ & $\%$ \\
\hline Crex crex & 1 & & 5 & 6 & 0.23 \\
\hline Gallinago gallinago & 1 & 2 & 3 & 6 & 0.23 \\
\hline Bubo bubo & & 3 & 3 & 6 & 0.23 \\
\hline Sturnus vulgaris & & 3 & 3 & 6 & 0.23 \\
\hline Mammalia & 107 & 1256 & 560 & 1923 & 74.19 \\
\hline Aves & 36 & 242 & 247 & 525 & 20.25 \\
\hline Amphibia, Reptilia, Pisces & 7 & 39 & 90 & 136 & 5.25 \\
\hline Evertebrata & 2 & 4 & 2 & 8 & 0.31 \\
\hline$\Sigma$ & 152 & 1541 & 899 & 2592 & 100.00 \\
\hline Diversity Index H' & 2.88 & 2.86 & 3.12 & 3.09 & \\
\hline
\end{tabular}

Others prey species (Period no.-no. of items): Ostatné druhy (Obdobie č.-počet):

Sorex araneus (2-1), Neomys anomalus (2-1), Neomys fodiens (1-1), Crocidura suaveolens (2-2; 3-1), Myotis mystacinus (2-2), Myotis myotis (1-2; 2-2), Eptesicus serotinus (3-1), Nyctalus noctula (1-1), Pipistrellus pipistrellus (2-1), Plecotus austriacus (2-1), Sciurus vulgaris (2-2), Muscardinus avellanarius (1-1; 2-1; 3-1), Micromys minutus (2-2; 3-1), Ondatra zibethicus (3-3), Terricola tatricus (2-2), Alexandromys oeconomus (3-1), Mustela erminea (2-1; 3-1), Mustela putorius (2-2), Mustela eversmanni (2-2), Podiceps nigricollis (3-3), Ixobrychus minutus (3-1), Anas querquedula (2-2), Aythya fuligula (3-1), Anatidae sp. (2-3; 3-1), Accipiter gentilis (3-1), Accipiter nisus (2-1), Circus aeruginosus (3-2), Falco peregrinus (2-1; 3-1), Tetrastes bonasia (3-1), Rallus aquaticus (2-1), Porzana porzana (3-3), Zapornia parva (3-1), Rallidae sp. (2-1), Pluvialis apricaria (3-1), Gallinago sp. (2-1), Lymnocryptes minimus (3-1), Columba palumbus (3-1), Streptopelia turtur (2-3), Tyto alba (1-1), Athene noctua (3-1), Strix aluco $(2-4 ; 3-1)$, Strix uralensis (2-1), Caprimulgus europaeus (2-2; 3-2), Lullula arborea (1-1), Galerida cristata (3-1), Hirundo rustica (21), Motacilla alba (2-2), Motacilla cinerea (3-1), Lanius collurio (1-1; 3-1), Erithacus rubecula (2-1), Emberiza citrinella (2-1; 3-1), Fringilla coelebs (3-2), Carduelis carduelis (3-1), Carduelis cannabina (3-2), Carduelis chloris (3-1), Coccothraustes coccothraustes (3-3), Passer domesticus (2-1; 3-1), Passer montanus (3-1), Corvus corax (3-2), Passeriformes sp. (2-5; 3-1), Aves sp. (2-1), Pelophylax ridibundus (3-2), Lacerta viridis (2-4), Lacerta agilis (2-3), Serpentes sp. (2-1), Lucanus cervus (1-1; 2-1; 3-2), Coleoptera sp. $(1-1 ; 2-3)$. 